MONOGRAPHIAE BOTANICAE

Vol. 98, 2008

AGNIESZKA BUDYŚ

THE SYNANTHROPISATION OF VASCULAR PLANT FLORA OF MIRES IN THE COASTAL ZONE (KASHUBIAN COASTAL REGION, N POLAND) - RANGE, REASONS FOR, AND SPATIAL CHARACTERISTICS

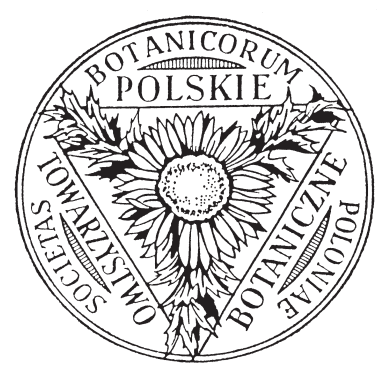


Edited with financial support of the Ministry of Science and Higher Education

\author{
EDITORIAL BOARD \\ Krystyna CZYŻEwSKA (Editor-in-Chief) \\ Małgorzata RUSZKIEWICZ-MICHALSKA (Editorial Assistant)
}

\title{
EDITORIAL COUNCIL
}

Jacek Herbich (Gdańsk), Bogdan JACKOwIAK (Poznań), Stefania LosTer (Kraków), Zbigniew MireK (Kraków), Romuald OlaczeK (Łódź) - president, Agnieszka PoPIElA (Szczecin), Valerijus RAŠOMAVIČıUs (Vilnius), Krzysztof RostaŃSKI (Katowice), Máría ZALIBEROVÁ (Bratislava), Waldemar ŻUKOWSKI (Poznań)

\section{EDITORIAL OFFICE}

Department of Algology and Mycology

University of Łódź

12/16 Banacha Str.

PL-90-237 Łódź

\section{COVER DESIGN BY}

Zdzisław WALTER

(C) Copyright by the Polish Botanical Society, Warszawa 2008 


\section{CONTENTS}

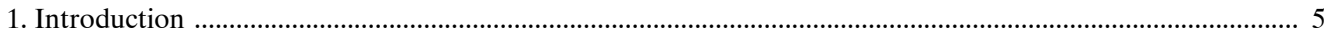

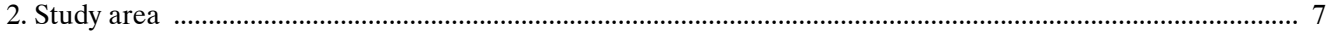

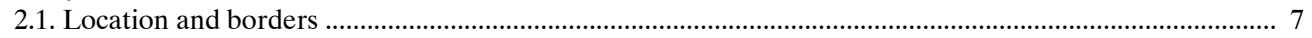

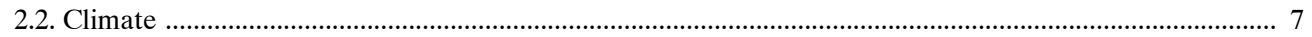

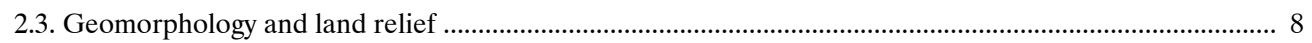

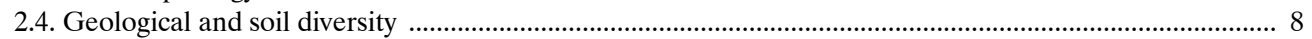

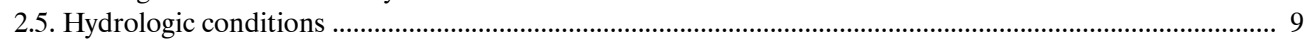

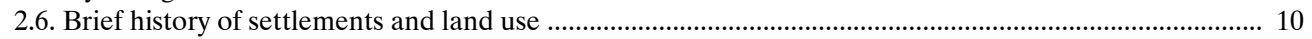

2.7. General features of contemporary vegetation ……………………………............................................ 10

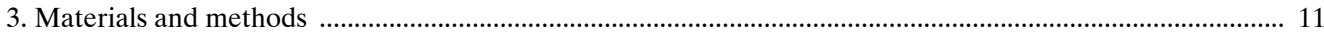

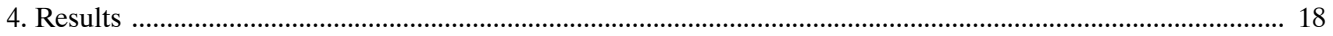

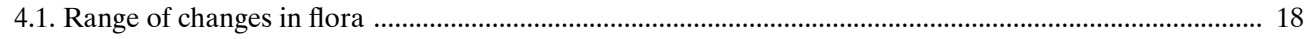

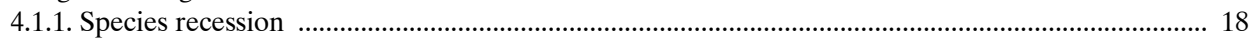

4.1.2. Enrichment of flora and characteristics of contemporary flora .................................................... 21

4.1.3. Dynamic tendencies of selected groups of species ......................................................................... 25

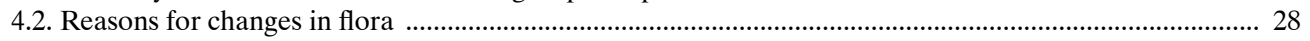

4.2.1. Reconstruction of changes in selected elements of environment .................................................. 28

4.2.2. Contemporary flora of raised bogs and transitional mires versus flora of fens submitted to different forms of anthropic pressure ........................................................................................ 30

4.2.3. Flora of sample plots and its relation to selected features of natural environment ....................... 33

4.2.4. Contemporary flora as an indicator of habitat changes .................................................................. 39

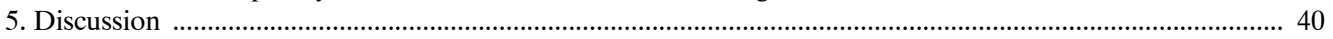

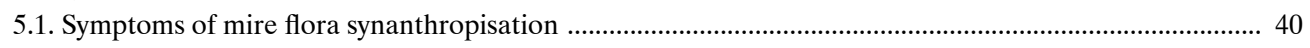

5.1.1. The regression of hemerophobic species ........................................................................................... 41

5.1.2. The expansion of hemerophilous species and neophytisation ....................................................... 41

5.2. The reasons for mire flora synanthropisation ………............................................................................. 42

5.3. The direction and progress of synanthropic changes ............................................................................ 44

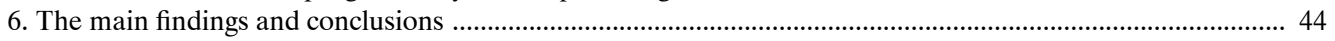

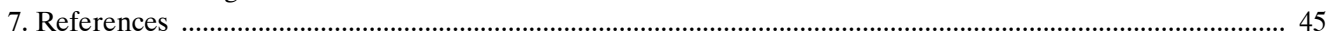

8. Synantropizacja flory roślin naczyniowych torfowisk w strefie przymorskiej (Pobrzeże Kaszubskie,

Polska Północna) - zakres, przyczyny i uwarunkowania przestrzenne (streszczenie) ........................................50 


\begin{abstract}
Agnieszka Budyś. The synanthropisation of vascular plant flora of mires in the coastal zone (Kashubian Coastal Region, N Poland ) - range, reasons for, and spatial characteristics. Monogr. Bot., Vol. 98, 55 pp., 2008.

The paper deals with symptoms, directions and actual state of anthropic transformation of the flora in various ecological types of peatlands in the coastal zone. The main purpose of the work was to define phases and characteristic features of flora's change in particular mires types and point the reasons for this process. The research was conducted in eastern part of Polish Baltic Coast (Kashubian Coastal Region). Contemporary flora was recorded in 2000-2004. The floristic list was completed with all data from former research. Chosen features of environment were analysed using topographic and geological maps and aerial photographs. Correlation between flora differentiation and some features of environment were analysed with multivariate analyses (DCA, PCA, RDA, CA) and GIS technique. There were 958 species recorded in the total flora of studied area, 93 among them became locally extinct. The big share in contemporary flora have synanthropic species and plants of wide ecological amplitude. Geographically alien species stand for $24 \%$ of nowadays flora. The results show that due to anthropic pressure, coastal raised bogs and fens are presently a mosaic of secondary habitats with very high floristic diversity, however raised bog habitats are more resistant to alien species expansion than fens. Despite deep flora disturbances, such as eurytopisation or allochtonisation, contemporary flora of coastal peatlands still has some characteristic features connected with geology, ecological differentiation and geobotanical location.
\end{abstract}

Key words: vascular plants, peatlands, raised bog, fen, anthropic pressure, species recession, floristic richness, GIS, multivariate analysis, Poland 


\section{INTRODUCTION}

Flora transformation, caused by human activity, is an element of changes of the plant cover, described as synanthropisation. The core of this process is replacement of natural systems by secondary ones formed by cosmopolitan, allochtonic and eurytopic components. Synanthropisation of the flora consists of e.g. expansion of hemerophilous species, retreat of hemerophobic species, apophytism and neophytism. This processes lead to deprivation of such flora and plant communities features, which have been predefined by the history of regional flora and climate (FALIŃSKi 1966, 1972, 1998, 2000; SuKopp 1972; KorNaś 1981; Olaczek 1982; Jackowiak 1998; Sudnik-WóJcikowsKa 1998). The main reason for contemporary transformations of flora is anthropogenic changes to the environment (e.g. Kornaś 1972, 1981).

Peatbogs are ecosystems that are considered particularly susceptible to any disturbance of abiotic conditions. Drainage works are usually the first stage of human activity at peatbogs and set the conditions for their further exploitation: peat excavation, agriculture or forestry (INGRAM 1992). Decrease of the groundwater level leads to breaking the anaerobic process of peat formation and begins the process of decay. As the effect soil structure changes, water capacity and permeability decreases (ОKRUsZKo 1993), and in consequence - the subsidence and the decession of the peatbog deposit starts (JASNOWSKI \& ILNICKI 1988).

The consequence of changing abiotic conditions are significant and usually irreversible changes in the plant cover of peatbogs (e.g. GöRS 1969; TALLIS 1983; JASNOwSKI \& ILNICKI 1988; Cross 1992). The high sensitivity of peatbog flora to changes in environmental factors is connected to relatively narrow ecological amplitude of the mire species. Peatbog plants are adapted to specific features of this habitat, such as: generally high water level that varies within the vegetation season; oxygen deficit; deficit of assimilable nitrogen, phosphorus and potassium; and high daily changes of temperatures at the ground surface (DieRsSEn 1992). The highest level of specialisation is represented by raised bog species, which occur in extremely acid and poor in nutrients habitats. In general, peatbog species are recognised as stenotopic organisms: higro- and hydrophytes, light-dependent and oligothermic plants (JASNOWSKI 1975; HeRBICH \& Herbichowa 2002).

Habitats and plant cover of mires in Poland, as in the rest of Europe, are contemporary greatly disturbed by anthropogenic pressure. It is estimated that in Poland more than $80 \%$ of surface covered by these ecosystems are affected by human activity (JASNOWSKI 1972; LIPKA 1984). Meadows and pastures dominate disturbed fens, and now cover ca $73 \%$ of their original surface. More than $50 \%$ of the area of raised bogs is covered by forest communities, which have developed spontaneously with the decrease of the groundwater level, or have been planted (JASNOWSKI et al. 1968; JASNOWSKI 1972; LIPKA 1984). A comparison of the historic diversity and composition of peat-forming phytocoenoses with the contemporary vegetation showed that two main processes overlap in the transformation of peatbogs: the disappearance of localities of mire species and the development of secondary vegetation (GöRS 1969; DIERSSEN 1982). The only available preliminary synthesis of changes in plant cover of peatbogs in Poland (JASNOWSKI 1972) showed that more than a half of the 
original area of peatbogs in the northern Poland is now covered by non-peatforming vegetation. This study proved that as the effect of the disappearance of suitable habitats, the localities of mire species have been lost. This process of retreat concerns rare species as well as those which were common in the past. Similar conclusions come out of local studies on flora of peatbogs (Herbichowa 1976; Olesiński \& Olkowski 1976; Polakowski 1976). Data compiled by JASNOWSKA \& JASNOWSKI (1977) showed that more than a half of the vascular plant species in the flora of peatbogs were in danger of extinction. Among mire plants retreating at the European scale there are taxa considered as relics and species that reach the borders of their range in European countries, e.g. Betula humilis, Salix myrtilloides, Saxifraga hirculus. In such cases, losing certain locations might result in the reduction of geographical range of species.

In comparison with the knowledge on the regression of peatbog flora, the process of its enrichment with ecologically and geographically alien species is poorly recognised. A typical feature of pristine mire ecosystems, especially raised bogs and transitional mires, is low diversity of their flora. In Poland the number of taxa in the natural vascular plant flora of mires is estimated at 130-230 species (see ToŁPA et al. 1967; JASNOwSKI 1972). Anthropic pressure has enormously increased the number of species in the contemporary flora of peatbogs (JASNOWSKi et al. 1968; JASNOWSKI 1972, 1975; DiERSSEN 1992; AABY 1994). Data collected by JASNOWSKI (1972) showed that the strongest expansion on peatbog habitats was shown by Poaceae and Asteraceae families. Among plants of foreign origin, the tendency to inhabit peatlands was demonstrated by 5 species of kenophytes. More recent studies prove that strongly transformed habitats are occupied not only by kenophytes but also by some archaeophytes and diaphytes (CELKA \& SzKudLARZ 2000).

Despite the commonly observed process of anthropogenic changes in the flora of peatbogs, comprehensive studies on this issue based on current data are lacking. Besides identification of quantitative and qualitative changes in the flora of peatbogs, it is important to determine more accurately than has yet been done, what is the relation between the direction of the transformation of flora and the range of habitat changes. Such an analysis would allow us to draw conclusions about the detailed reasons for the changes in flora and would also explain the sensitivity of particular species to disturbance.

Because of numerous threats to the persistence of mires, their significance for the functioning of the natural environment and their scientific value, the problems relating to their efficient conservation are of crucial importance at present (e.g. TовOLSKI 2003). This is expressed in action programs at national and international levels, such as the Habitats Directive or the European Ecological Network Natura 2000 (Council Directive 92/43/EEC). Determination of the stage of transformation of flora, and drawing conclusions considering the reasons for this process would be a starting point for the prognoses for further changes in the vegetation of peatbogs, and at the same time would provide the basis for proper planning of conservation measures.

The main aim of this study was to recognise the range of anthropogenic changes of flora in ecologically diverse mires in the Polish coastal zone, and to define the spatial aspects as well as the reasons for this process.

This aim was achieved by completing the following research targets:

- comparison of historical and contemporary flora of chosen mires, representative of the Polish coastal zone,

- identification of symptoms, stages and the specific features of the transformation of flora in disturbed peatbog habitats, 
- identification of dynamic tendencies among the selected components of flora,

- defining the main stages of anthropogenic changes in the environment of the study area,

- determination of relations between the quantitative, qualitative and spatial variability of flora and the forms of anthropic pressure as well as the identification of the most important factors that influence the structure of contemporary flora of transformed peatbog habitats.

There was a hypothesis formulated that the extent and symptoms of flora synanthropisation in peatlands depend both on the form of human pressure and ecological type of mire.

For this study the fragment of lowlands, which extends between spits and moraine hills along the whole coastline of the Baltic Sea (KONDRACKI 2001) was selected. This area consists of a complex of fens that predominate the area, and three raised bogs of the Baltic type. In terms of geomorphologic conditions, climate features and typological diversity of these peatbogs, the selected fragment of Kashubian Coastal Region is representative of the eastern section of the coast. Because of the long-term, direct and indirect human pressure, this area at present is a unique mosaic of habitats, diverse in respect of the stage of transformation and the way of land use. This area is distinguishable from other similar complexes by its relatively rich, although not complete, floristic documentation, originating from the 19th and 20th century.

\section{STUDY AREA}

\subsection{Location and borders}

According to the regional classification by Augustowski $(1969,1974)$ used in this study, the studied area is located within the Kashubian Coastal Region and consists of the Błota Przymorskie Plain and northern part of Płutnica Valley. The Błota Przymorskie Plain is a low-lying land about $21.5 \mathrm{~km}$ long, and from $1 \mathrm{~km}$ to $4.2 \mathrm{~km}$ wide, extending alongside the seacoast between the belt of coastal dunes and the edge of the moraine heights. In the eastern part it is divided by Ostrowo Moraine into the Czarna Wda Valley and the Bielawskie Błoto raised bog. The Płutnica Valley is conected to the Błota Przymorskie Plain in its eastern-south part. The total coverage of the studied area is $74.2 \mathrm{~km}^{2}$ (Fig. 1).

The border of the study area is natural along almost the whole length and generally follows the border between peatbog habitats and the sand or sand-clay formations that occur in the surroundings (Fig. 2).

\subsection{Climate}

The area of the Kashubian Coastal Region, included by KwIECIEŃ \& TARANOwsKa (1974) in the Climatic Region of the Open Sea, remains under the clear influence of the Baltic Sea. The climate of this area is distinguished by warmer winters and cooler summer months than inland, later spring and longer autumn, relatively high annual total rainfall 


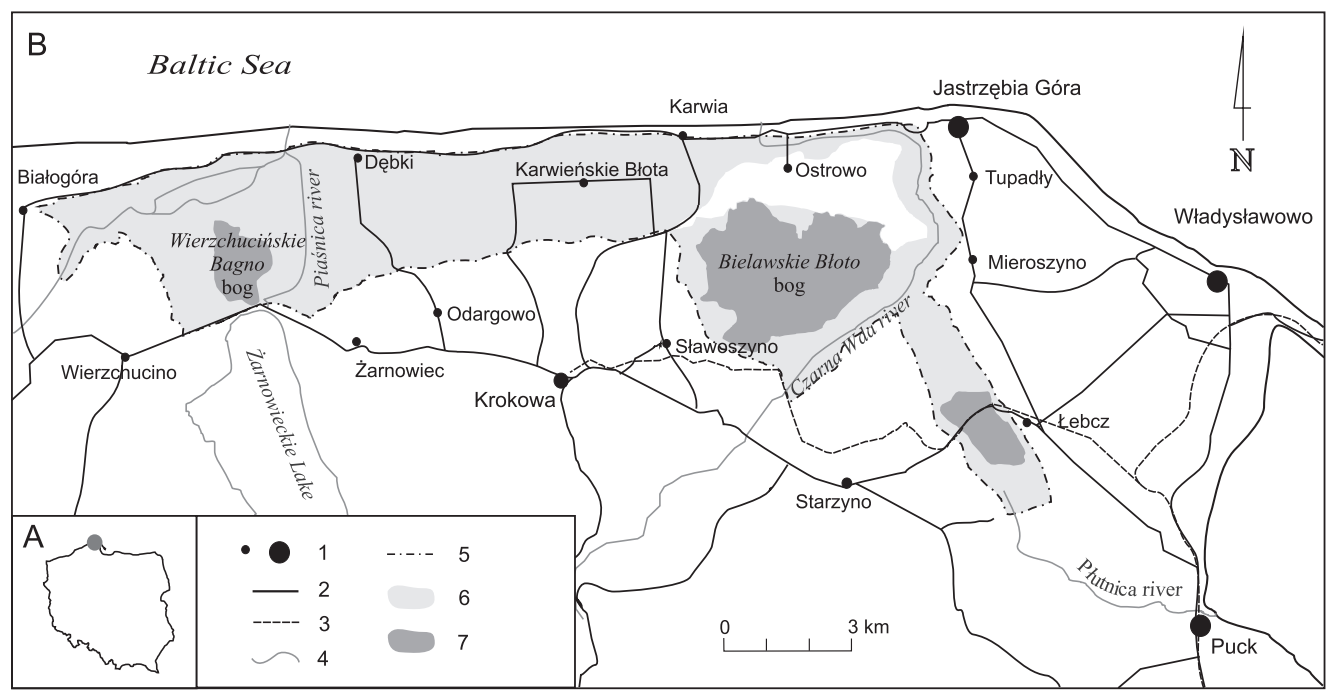

Fig. 1. Localisation and habitat differentiation of studied area

A - general localisation; B - studied area boundaries and topography of surroundings;

1 - human settlements; 2 - main and local roads; 3 - railway; 4 - rivers; 5 - boundary of studied area; 6 - habitat of fen; 6 - habitat of raised bog and transitional mire

(550-700 $\mathrm{mm}$ ) and high air humidity (annual average 8.3\%). In this area the mean ambient temperature of January is $-1.4^{\circ} \mathrm{C}$, but in July it is $13.8^{\circ} \mathrm{C}$ (Gerstmannowa 1978-1981). This area is distinguished by frequent mists and high wind speeds (AugustowsKi 1969).

\subsection{Geomorphology and land relief}

The land relief of the Kashubian Coastal Region was formed in the Quaternary by glaciers and fluvioglacial water activity (AUgustowsKi 1969). The typical landscape of this area is formed by morainal plateau and marginal stream valleys (Fig. 2). Another feature typical of this region is presence of sandy spits formed by sea accumulation and aeolic activity.

The Błota Przymorskie Plain and Płutnica Valley are filled mainly by Holocene formations: peat, silty sands, and silts of river-floors or of non-drained depressions (Detailed geological map... 1978, 1985, 2002).

The studied area is a flat lowland, located at an altitude of ca 0.3-5 m a.s.l., of rather monotonous land relief.

\subsection{Geological and soil diversity}

The diversity of the soils in Kashubian Coastal Region is closely associated with its geomorphology: at highlands brown soils occur, formed of clay, loam and clayey sands, and podsols, formed of mound, zandr and river sands. Marginal stream valleys are filled mainly with hydrogenic soils, formed of peat and moorsh (WITEK et al. 1974). 


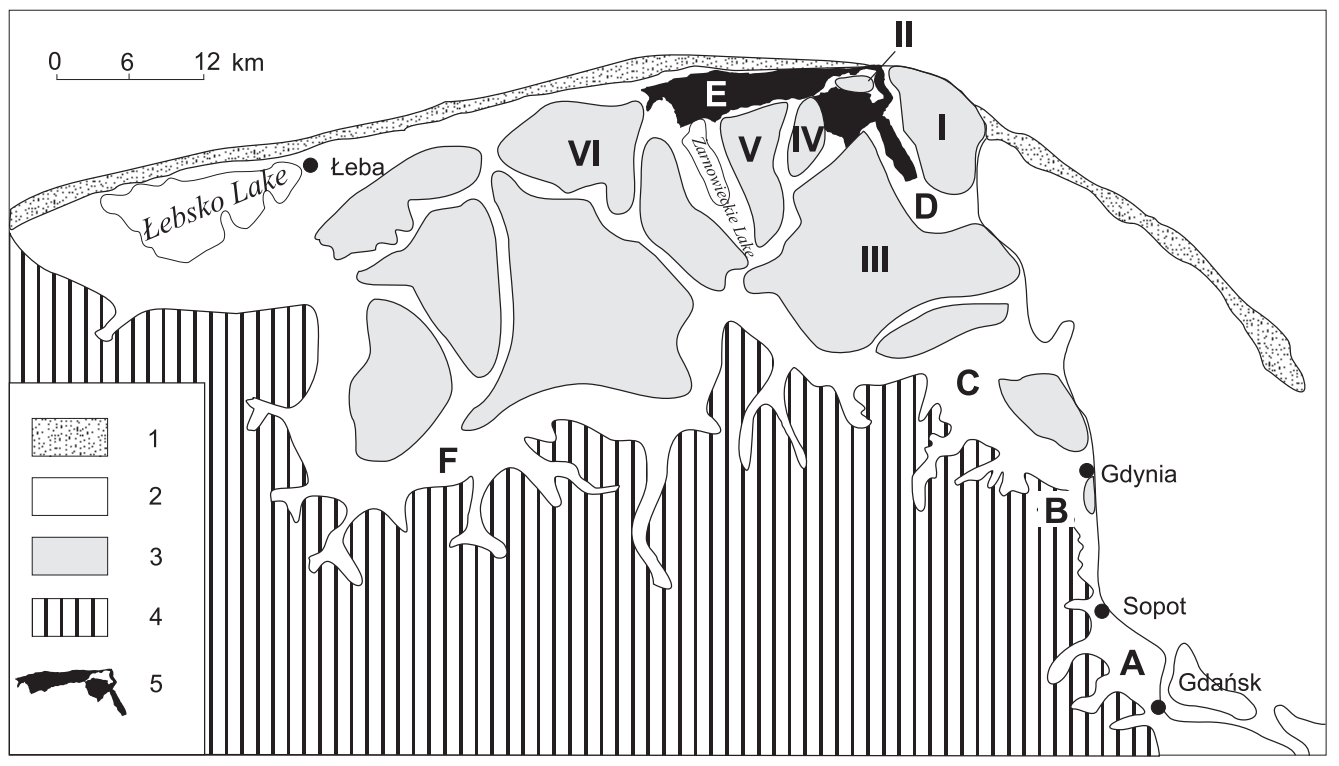

Fig. 2. Localisation of studied area against the background of geomorphology of Kashubian Coastal Region (after Augustowski 1969, changed)

1 - sand-bar; 2 - marginal stream valleys, valleys, troughs: A - Oliwa-Sopot Terrace; B - Redłowo Downland; C - Kashubian Meander; D - Płutnica Valley; E - Błota Przymorskie Plain; F - Reda-Łeba Marginal Stream Valley; 3 - morainal plateau of Kashubian Coastal Region: I - Swarzewo Moraine; II - Ostrowo Moraine; III - Puck Moraine; IV - Sławoszyno Moraine; V - Żarnowiec Moraine; VI - Osieki Moraine; 4 - Kashubian Lakeland; 5 - studied area

Fens prevail on the studied area. The deepest peat deposits ( $7 \mathrm{~m}$ thick), were formed in the valley of the Piaśnica river (SzAFRANówna 1926). Three deposits of raised bogs were located in the study area: Bielawskie Błoto, Wierzchucińskie Bagno and the Łebcz raised bog.

Where unfavourable changes of hydrological conditions occurred, peat soils were transformed into peat-moorsh, moorsh-mineral, or mucky soils (Soil-agricultural map 1973), and locally a complete decession of peat and exposure of the mineral substratum took place.

\subsection{Hydrologic conditions}

The largest river of the studied area is the Piaśnica, which is the only natural outflow of Żarnowieckie Lake. Water regime in the Piaśnica river basin were strongly transformed in the 60's of the 20th century by the digging out the so-called Channel of the Old Piaśnica, the regulation of the river outlet and the building of the pump station, which led to the disappearance of the one of the two beds of the Piaśnica river, formerly of equal importance. One of the largest lakes within the study area was Ostrowskie Lake, which was located in the lower part of the Czarna Wda Valley, but it was drained in 1950s (Aerial photographs 1947, 1958). A few small lakes and astatic water bodies remain in the study area, such as 
in the region of Bielawskie Błoto bog. The typical feature of the hydrographical network in the Błota Przymorskie Plain and Płutnica Valley is its strong transformation by human activity, which consisted of regulation and embankments of rivers and the creation of an artificial drainage system (NARWOJsz 2000).

\subsection{Brief history of settlements and land use}

The Błota Przymorskie Plain was inhabited in the middle ages. Villages were built at its mineral and organic edges, as e.g. Karwia and Dębki, which were documented for the first time in the 13th century. Agricultural use of fragments of wetlands was possible only in the end of the 16th century, when Dutch settlers started building the drainage system at Karwieńskie Wetlands. They built settlements of a typical two-row arrangement on the peaty substratum (BIERNAT et al. 2000). The first signs of peat exploitation are visible in maps from the second half of the 19th century, however it might be assumed that peat extraction in this area had taken place earlier (Topographic map 1889). Rapid development of sea-side villages, stimulated by tourism, was observed between the two world wars. After the Second World War, a gradual intensification occurred in farming and forestry. Until the end of 1970s the industrial exploitation of the largest raised bog deposit in the studied area, at Bielawskie Błoto, was started (MACHNIKOWSKI et al. 1985). During the 1990s large areas of meadows and arable land were gradually excluded from land use and exploitation. At present almost all coastal villages in this area have lost their agricultural character and became tourist resorts (Dębki, Karwia and Karwieńskie Błota II). The pressure of recreational use has led to uncontrolled development and gradual expansion of all kind of settlements and camping sites within the area of former peatbog habitats.

\subsection{General features of contemporary vegetation}

In the study area communities of the Molinio-Arrhenatheretea class prevail, represented mainly by wet meadows and pastures (Molinion and Calthion). Forest and shrub cover now more than $20 \%$ of the study area. This includes swamp forests in raised bogs that have been drained and planted with coniferous (pine, spruce) or broadleaved trees (birch, alder, aspen). Communities of raised bogs and transitional mires were preserved only as remnants and cover small patches of land. They are represented by Sphagnum communities with cross-leaved heath (Erico-Sphagnetum medii), moist heathlands (Ericetum tetralicis community) and Rhynchosporetum albae with the occurrence of Rhynchospora fusca (Herbichowa 1972; Budyś 2001). Sedge communities of the Caricetalia nigrae order, representing vegetation of fens, are considerably wide distributed. Phytocoenoses of the Nardo-Callunetea class developed mainly on fragments of Bielawskie Błoto, where the soil moisture had been badly disturbed, and are also scattered at the edges of forests and sandy roads. True rush communities (Phragmition) developed along larger water bodies and in drainage ditches and channels. Sedges (Magnocaricion) occupied the wet parts of the area, e.g. in Czarna Wda Valley and on Piaśnickie Łąki meadows. Aquatic communities (Lemnetea and Potametea) were observed mainly in drainage ditches, 
channels and rivers. Lakes and astatic water bodies have oligo- or mesotrophic character and are the habitat of species of Utricularietea intermedio-minoris and Littorelletea uniflorae classes. On temporary wet mineral habitats, e.g. in potholes of ground roads, phytocoenoses of the Isoëto-Nanojuncetea class develop. Communities of silt-covered soils (Bidentetea tripartiti) cover slightly more fertile and usually more moist habitats, mainly the embankments of drainage ditches. Small patches of communities with the species of the Koelerio glaucae-Corynephoretea canescentis class were encountered, e.g. on mineral hills in the region of Łąki Dębkowskie. Among segetal communities of weeds the Centauretalia cyani order prevailed. Ruderal vegetation is represented by communities of Artemisietea and Agropyretea intermedio-minoris classes and Sisymbrietalia and Plantaginetalia majoris orders.

\section{MATERIALS AND METHODS}

\section{Materials and methods of flora feature analysis}

Sources of floristic data and investigation periods. Contemporary vascular plant flora was listed during the author's field research (BuDYś, unpubl.) carried out in 2000-2004 and supplemented with data from other up-to-date investigations: Herbichowa et al. (2001) and MinAsiewicz et al. (2004). The studied area was divided into 122 squares $1 \mathrm{~km} \times 1 \mathrm{~km}$ belonging to six squares $10 \mathrm{~km} \times 10 \mathrm{~km}$ within an ATPOL grid squares (ZAJĄC A. 1978): AC $36,37,38,46,47,48$. In each of these, the species and their abundance were noted from all habitats occurring there. The planted species were omitted. A single square $1 \mathrm{~km} \times 1 \mathrm{~km}$ was regarded as a single species locality. There were 4923 floristic relevés made in total. The locality of each relevé was noted in an aerial photograph (Aerial photographs 19961997) or saved in a GPS receiver. The contemporary floristic list was completed with all available data from previous research -42 published and unpublished sources concerning the plant cover of the studied area were used (BuDYś 2005). Because of the fragmentary character of archival data, the exact time of extinction or settlement of particular plant species was impossible to define. Despite this, some stages of flora transformation were analysed. Consequently, there were five investigation periods distinguished: (I) 1809-1896, (II) 1897-1940, (III) 1941-1979, (IV) 1980-1996, (V) 1997-2004.

Floristic data base and species classifications. There are 81019 records in the floristic data base -74425 pertaining to contemporary flora and 6594 to historical one. The plant names, with a few exceptions, follow MireK et al. (2002).

According to the number of species localities, six classes of frequency were defined (Table 1). Sociological groups of species (Table 2) are based on phytosociological classification of Matuszkiewicz (2001) and, in the case of mire species, of Dierssen (1982). All species with undefined phytosociological amplitude are grouped in the 'other species' class.

The geographic-historical classification of species follows Konnaś (1981) and MiREK (1981). Anthropophytes are divided into archaeophytes, kenophytes (epecophytes, hemiagriophytes, holoagriophytes) and diaphytes (with ephemeral species). The following sources of information about the geographic-historical status of species in the Pomorze 
Table 1

The rules of defining frequency classes

\begin{tabular}{|c|c|c|c|}
\hline Frequency class & Number of localities & \% of localities & Definition of frequency \\
\hline I & $1-5$ & $1-3$ & very rare \\
\hline II & $6-17$ & $4-11$ & rare \\
\hline III & $18-35$ & $12-24$ & widespread \\
\hline IV & $36-60$ & $25-40$ & frequent \\
\hline V & $61-90$ & $41-61$ & very frequent \\
\hline VI & $>90$ & $>61$ & common \\
\hline
\end{tabular}

region were used: Kornaś (1968), Zając E.U. \& Zając A. (1975), ZająC A. et al. (1998), MARKOWSKI (unpubl. data). To assess the degree of flora transformation the following indices of anthropogenic changes in flora were used (JACKOWIAK 1990): anthrophytisation index $\left(\mathrm{W}_{\text {an }}\right)$, archaeophytisation index $\left(\mathrm{W}_{\text {arch }}\right)$, kenophytisation index $\left(\mathrm{W}_{\text {ken }}\right)$, index of flora modernisation $\left(\mathrm{W}_{\mathrm{m}}\right)$ and index of fluctuation changes $\left(\mathrm{W}_{\mathrm{f}}\right)$.

According to the classification of RAUnKIAER (1905), six groups of life forms were defined: phanerophytes, chamaephytes, geophytes, hemicryptophytes, hydrophytes (with helophytes) and terophytes.

Apophytism index $\left(\mathrm{I}_{\mathrm{ap}}\right)$ and naturalisation index $\left(\mathrm{I}_{\text {nat }}\right)$ were used to assess the dynamic tendencies among species in contemporary flora (JACKOWIAK 1990). In the analysis, species that were not settled and species of low frequency (with less then 10 localities) were not included.

\section{Habitat classification in respect to status of hemeroby}

The hemeroby scale (JALAS 1955; SukOPP 1972, 1976; KowARIK 1988) takes into account the range of anthropogenic changes in ecosystems, judged on habitat and phytosociological and floristic criterions. In the present work, the six-level scale of hemeroby proposed by Sukopp (1972) was detailed by division mesohemerobic and euhemerobic degrees into sub-grades. It was also assumed that ahemerobic and metahemerobic degrees were not represented within the studied area. Finally, the used hemeroby scale appears as follows:

1. Oligohemerobic habitats - no direct anthropic pressure, no significant changes in soil or hydrological conditions, natural plant cover (e.g. pools and their shores, moist heathlands with Erica tetralix).

2. Mesohemerobic habitats - habitats changed by human activity, the influence of anthropic pressure indirect (drainage), direct but periodical (e.g. peat exploitation, management of drainage system) or direct and permanent (hay-meadow farming, forestry) or habitats changed by natural factors such as animals burrowing. The soil substratum transformed by desiccation (moorshing). Sub-grades:

- $\alpha$-mesohemerobic - habitats with more or less natural plant cover, no direct form of human pressure or pressure periodical (e.g. terrestrialized pools, post-exploitation digs); 
Table 2

Sociological groups in the flora of studied area (symbols in Roman numerals). Phytosociological classification after MATUSZKIEWICZ (2001)

\begin{tabular}{|c|c|c|}
\hline \multicolumn{2}{|c|}{ Sociological groups } & Phytosociological classification \\
\hline \multicolumn{2}{|c|}{ Oligo- and mesotrophic water species (I) } & Littorelletea, Utricularietea \\
\hline \multicolumn{2}{|c|}{ Eutrophic water and spring species (II) } & Lemnetea, Potametea, Montio-Cardaminetea \\
\hline \multicolumn{2}{|c|}{$\begin{array}{l}\text { Raised bog and transitional mire species, swamp } \\
\text { pine forest species, swamp birch forest species (III) }\end{array}$} & $\begin{array}{l}\text { Oxycocco-Sphagnetea, Scheuchzerietalia palustris, } \\
\text { Vaccinio uliginosi-Pinetum sylvestris, Betuletum } \\
\text { pubescentis }\end{array}$ \\
\hline \multirow[t]{2}{*}{ Fen species (IV) } & poor fen (IVa) & Scheuchzerio-Caricetea nigrae, Caricetalia nigrae \\
\hline & $\begin{array}{l}\text { neutral and rich fen } \\
(\mathrm{IVb})\end{array}$ & Caricetalia davallianae \\
\hline \multicolumn{2}{|c|}{$\begin{array}{l}\text { Swamp alder forest species and sedge communities } \\
\text { species (V) }\end{array}$} & Alnetea glutinosae, Magnocaricion \\
\hline \multicolumn{2}{|c|}{ Rushes species and species of river's bank (VI) } & $\begin{array}{l}\text { Phragmitetea, Phragmition, Sparganio-Glycerion } \\
\text { fluitantis }\end{array}$ \\
\hline \multicolumn{2}{|c|}{ Moist mineral soil and silt-covered soil species (VII) } & Isoëto-Nanojuncetea, Bidentetea tripartiti \\
\hline \multirow{2}{*}{$\begin{array}{l}\text { Meadow, tall herbs } \\
\text { community and pasture } \\
\text { species (VIII) }\end{array}$} & moist (VIIIa) & $\begin{array}{l}\text { Molinio-Arrhenatheretea, Molinietalia, } \\
\text { Trifolio fragiferae-Agrostietalia stoloniferae }\end{array}$ \\
\hline & semi-dry (VIIIb) & Arrhenatheretalia \\
\hline \multicolumn{2}{|l|}{ Heathland species (IX) } & Nardo-Callunetea \\
\hline \multicolumn{2}{|c|}{ Sandy grassland and dune species (X) } & $\begin{array}{l}\text { Koelerio glaucae-Corynephoretea canescentis, } \\
\text { Ammophiletea }\end{array}$ \\
\hline \multicolumn{2}{|c|}{$\begin{array}{l}\text { Termophilous forest-edge species and xerothermic } \\
\text { grassland species (XI) }\end{array}$} & Festuco-Brometea, Trifolio-Geranietea sanguinei \\
\hline \multicolumn{2}{|c|}{ Rich deciduous forest and shrub species (XII) } & $\begin{array}{l}\text { Querco-Fagetea, Salicetea purpureae, Rhamno- } \\
\text { Prunetea }\end{array}$ \\
\hline \multicolumn{2}{|c|}{ Pine forest and acid oak forest species (XIII) } & Vaccinio-Piceetea, Quercetea robori-petraeae \\
\hline \multicolumn{2}{|c|}{ Salty marshes species (XIV) } & Asteretea tripolium, Cakiletea maritimae \\
\hline \multirow[t]{4}{*}{$\begin{array}{l}\text { Synanthropic habitat } \\
\text { species (XV) }\end{array}$} & ruderal (XVa) & $\begin{array}{l}\text { Artemisietea, Agropyretea intermedio-repentis, } \\
\text { Sisymbrietalia }\end{array}$ \\
\hline & trampled places $(\mathrm{XVb})$ & Plantaginetalia majoris \\
\hline & clearings (XVc) & Epilobietea angustifoli \\
\hline & crop land (XVd) & $\begin{array}{l}\text { Stellarietea mediae, Centauretalia cyani, Polygono- } \\
\text { Chenopodietalia }\end{array}$ \\
\hline \multicolumn{2}{|l|}{ Other species (XVI) } & taxa with wide sociological amplitude \\
\hline
\end{tabular}

- $\beta$-mesohemerobic - spontaneous vegetation in significantly disturbed habitats or habitats with semi-natural and anthropogenic phytocoenoses, anthropic pressure irregular (e.g. forests and shrubs, non-surfaced ground roads);

$-\gamma$-mesohemerobic - habitats with semi-natural phytocoenoses formed by regular anthropic pressure such as hay-meadow farming (e.g. drainage ditches, meadows, mown sedge communities, pastures, sandy grasslands). 
3. Euhemerobic habitats - disturbed by permanent and intensive human pressure, with ruderal and segetal vegetation. Soil and hydrological conditions significantly changed. Sub-grades:

- $\alpha$-euhemerobic - habitats changed by transportation, settlement, tourism, soil substratum disturbed by allochtonic material disposal or fires (e.g. hard-surfaced roads, built-up area);

- $\beta$-euhemerobic - habitats formed by agriculture or waste disposal sites, soil substratum significantly changed or entirely anthropogenic, floristic instability (waste disposal sites, arable fields, gardens).

4. Polyhemerobic habitats - anthropogenic habitats, artificial substratum (concrete, asphalt), instable synanthropic vegetation, pioneer vegetation.

\section{Habitat classification with respect to its genesis and forms of land use}

Ecological types of mire and forms of anthropic pressure which influenced the flora of studied sites are the basis of defining 35 types of habitat (Table 3). As well as the habitats formed or significantly transformed by direct forms of anthropic pressure, the habitats influenced by drainage as well as more or less natural habitats were considered.

\section{Materials and methods of environmental change analysis}

Analysis of chosen elements of environment and reconstruction of their changes was based on the following materials:

- topographic maps: 1810 (surveyed in 1796-1806), 1889 (surveyed in 1862-1875), 1911 (surveyed in 1877), 1918 (surveyed in 1877), 1935 (surveyed in 1928), 1940, 1941, 1942 (surveyed in 1934-1939);

- maps of geological deposits (Detailed geological map... 1978, 1985, 2002);

- drafts from geological documentation of peat deposits (Geological documentation... 1957, 1963, 1968);

- archival and up-to-date aerial photographs (1947, 1958, 1964, 1976, 1984, 1996-1997),

- digital vector topographic map (Topographic map 2000-2002).

Topographic maps 1889 and 1940-1942, aerial photographs from 1964 and 1996-1997 and geological maps were chosen for detailed analyses with GIS techniques (ArcGis 8.3 software). These cartographic materials were transformed into raster layers (UTM projection, $34 \mathrm{~N}$ zone) by rectification. Screen digitisation allowed the creation of several vector maps: maps of land cover classes in the above-mentioned periods of time, maps of former road systems and hydrological networks (based on Topographic map 1889), maps of geological deposits, and maps of the boundary between raised bogs/transitional mire and fen habitat. There were nine classes of land cover distinguished with regard to type of land use or the type of dominating phytocoenosis: (1) the area with no signs of disturbances, (2) pools, (3) forests, (4) shrubs, (5) agricultural land (meadows, pastures, arable fields), (6) post-exploitation digs, (7) post-exploitation digs with shrubs, (8) built-up areas, (9) other disturbances (area disturbed by ploughing, turf cutting or fire). The maps of land cover classes were used to create a synthetic map of the age of disturbances according to the cartographic model presented in Figure 3. 
Table 3

Forms of anthropic pressure changing habitats within raised bog/transitional mire and fen

\begin{tabular}{|c|c|c|c|}
\hline \multicolumn{2}{|c|}{ Symbol of habitat type } & \multirow[t]{2}{*}{ Anthropic pressure } & \multirow[t]{2}{*}{ Type of habitat } \\
\hline $\begin{array}{c}\text { Raised bog/ } \\
\text { transitional mire } \\
\text { habitat }\end{array}$ & Fen habitat & & \\
\hline A_1 & B_1 & none & $\begin{array}{l}\text { pools, canals waters, sedge com- } \\
\text { munities, Myrica gale communi- } \\
\text { ties, moist heathlands }\end{array}$ \\
\hline A_2 & B_2 & peat exploitation & $\begin{array}{l}\text { post-exploitation digs and their } \\
\text { embankments }\end{array}$ \\
\hline A_3 & - & drainage & terrestrialized pools \\
\hline A_4 & B_4 & drainage & forests \\
\hline A_5 & B_5 & drainage & shrubs \\
\hline- & B_6 & drainage & sandy grasslands \\
\hline A_7 & B_7 & drainage & dry heathlands \\
\hline A_8 & B_8 & drainage & burnt places \\
\hline- & B_9 & intensive hay-meadow farming & mown and sown meadows \\
\hline A_10 & B_10 & extensive hay-meadow farming & mown meadows and pastures \\
\hline A_11 & B_11 & $\begin{array}{l}\text { former hay-meadow farming or } \\
\text { grazing }\end{array}$ & $\begin{array}{l}\text { abandoned meadows and pas- } \\
\text { tures }\end{array}$ \\
\hline A_12 & B_12 & forestry & trees plantations, clearings \\
\hline A_13 & B_13 & $\begin{array}{l}\text { creating and conservation of drain- } \\
\text { age system }\end{array}$ & $\begin{array}{l}\text { drainage ditches and their em- } \\
\text { bankments }\end{array}$ \\
\hline- & B_14 & rivers regulation & canals banks \\
\hline A_15 & B_15 & agriculture & crop fields and abandoned fields \\
\hline- & B_16 & human settlements & $\begin{array}{l}\text { cottage surroundings, by-fence } \\
\text { habitats, flowers beds, camping } \\
\text { sites }\end{array}$ \\
\hline A_17 & B_17 & transport & $\begin{array}{l}\text { ground roads and roads sides, } \\
\text { trampled places }\end{array}$ \\
\hline A_18 & B_18 & waste disposal & waste disposal places \\
\hline A_19 & B_19 & allochtonic substrate disposal & allochtonic mineral grounds \\
\hline A_20 & - & other disturbances of soil surface & ploughed or rooted places \\
\hline- & B_21 & creating of artificial surfaces & concrete and asphalt surfaces \\
\hline
\end{tabular}

Some environmental features were analysed within a grid of $1 \mathrm{~km} \times 1 \mathrm{~km}$ squares (detailed ATPOL grid). In order to prepare the digital map of squares a draft of the ATPOL map (ZAJĄC A. \& ZAJĄC M. (eds.) 1996-1998) was digitised and saved as a vector layer. Then the vector model of the grid was complemented by linear interpolation of grid nodes in a Cartesian coordinate system. 


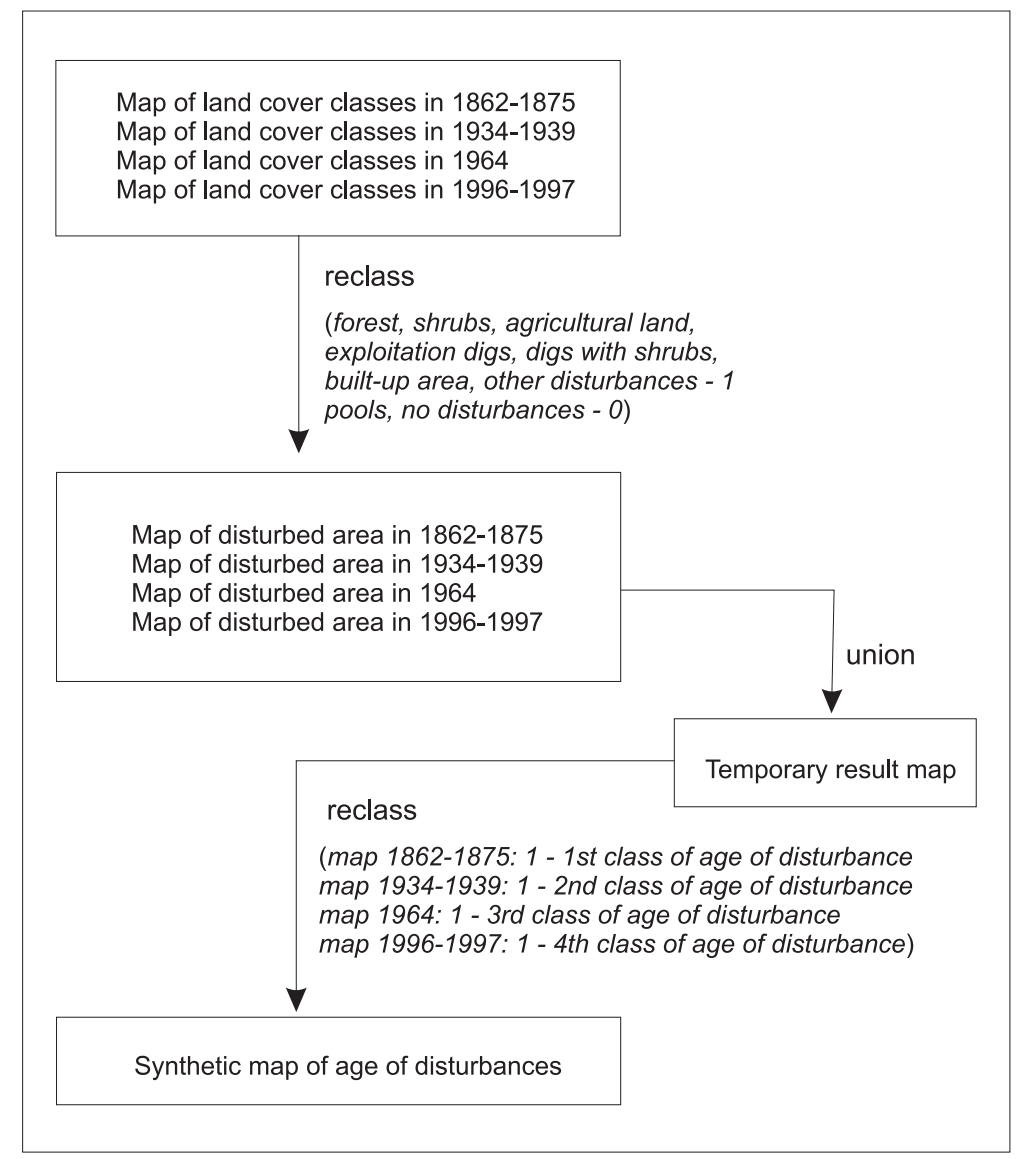

Fig. 3. Cartographic model used for preparation of synthetic map of disturbances' age (in reclass options the new value of attribute of each class was given after hyphen)

\section{Methods of analysis of relationship between spatial differentiation of flora and environment features}

The multivariate analyses and GIS methods were applied to define the correlation between flora and environmental features.

The following multivariate analyses, made with Canoco for Windows 4.5 software, were used: DCA (detrended correspondence analysis), PCA (principal components analysis), RDA (redundancy analysis) and CA (correspondence analysis). The type of analysis was chosen with regard to the rules given by Ter BraAK \& Prentice (1988), Ter BraAK \& Šmilauer (2002) and Lepš \& Šmilauer (2004). In Table 4 a short summary of the options of each analysis is given. The results were interpreted mainly by studying the relationship between particular variables and sample scores (inter set correlation), as well as correlations (r) between variables (Jongman et al. 1987; PIERNIK 2005). The statistical significance of the RDA model and the significance of each variable in the forward selection procedure was tested using the Monte Carlo test $(\mathrm{p}<0.05)$ (Ter BraAK \& Prentice 1988). In order to assess which part of variability in species data set can be explained by geological factors 
Table 4

Researched problems and methods applied to solve them

\begin{tabular}{|c|c|c|}
\hline Problem & \multicolumn{2}{|r|}{ Research procedure } \\
\hline \multirow{5}{*}{ 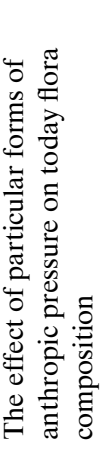 } & Method & $\mathrm{CA}$ \\
\hline & Samples & $\begin{array}{l}\text { types of habitats within raised bog/transitional mire vs. fen, influenced by } \\
\text { analogical form of anthropic pressure }\end{array}$ \\
\hline & Species data & $\begin{array}{l}\text { species composition with number of records of each species (sum of } \\
\text { records of particular species in given habitat divided by sum of records of } \\
\text { all species noted in this habitat) }\end{array}$ \\
\hline & $\begin{array}{l}\text { Supplementary } \\
\text { variables }\end{array}$ & $\begin{array}{l}\text { 1. mean values of Zarzycki indicators ( } \mathrm{TR}, \mathrm{R}, \mathrm{H}, \mathrm{L}, \mathrm{W}), 2 \text { - sociological } \\
\text { structure, } 3 \text {. living forms, } 4 \text { - anthropophytisation index, } 5 \text { - number of } \\
\text { species }\end{array}$ \\
\hline & Options & inter-sample distance, Hill's scaling \\
\hline 0 & Method & PCA \\
\hline$\stackrel{1}{0}$ & Samples & sample fields ( $\geq 50$ species in flora only) \\
\hline & Species data & floristic composition (binary) \\
\hline 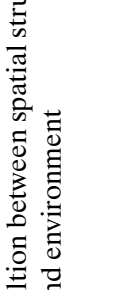 & $\begin{array}{l}\text { Supplementary } \\
\text { variables }\end{array}$ & $\begin{array}{l}\text { 1. percentage of the area of bog/transition mire vs. fen, } 2 \text {. percentage of } \\
\text { the area of land cover-classes, } 3 \text {. percentage of the area of age-classes of } \\
\text { disturbance, } 4 \text {. percentage of the area of geological deposits' type, } 5 \text {. the } \\
\text { length of roads and the length of ditches, } 6 \text {. number of relevés made in } \\
\text { habitats influenced by given form of human pressure, } 7 \text {. mean values of } \\
\text { Zarzycki indicators (TR, R, H, L, W), } 8 \text {. sociological structure of the flora, } \\
\text { 9. geographic-historical structure of the flora, } 10 \text {. percentage of species } \\
\text { living forms, } 11 \text {. number of species }\end{array}$ \\
\hline 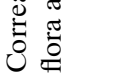 & Options & $\begin{array}{l}\text { centre by species, inter-sample distances, species scores divided by stand- } \\
\text { ard deviation }\end{array}$ \\
\hline & Method & RDA, variance partitioning \\
\hline : & Samples & sample fields ( $\geq 50$ species in flora only) \\
\hline$\vec{\Xi}$ & Species data & floristic composition (binary) \\
\hline 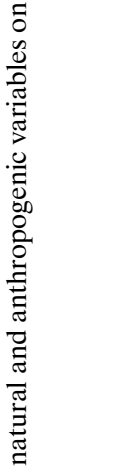 & $\begin{array}{l}\text { Environmental } \\
\text { variables }\end{array}$ & $\begin{array}{l}\text { Step I } \bullet \text { Environmental variables: } 1 \text {. percentage of the area of bog/transi- } \\
\text { tional mire vs. fen, } 2 \text {. percentage of the area of geological deposits' type, } 3 \text {. } \\
\text { percentage of the area of land cover-classes, } 4 \text {. percentage of the area of } \\
\text { age-classes of disturbance, } 5 \text {. the length of roads and the length ditches } \\
\text { Step II } \bullet \text { Environmental variables - variables connected with type of sedi- } \\
\text { ments: } 1 \text {. percentage of the area of bog/transitional mire vs. fen , 2. per- } \\
\text { centage of the area of geological deposits' type; Covariables - variables } \\
\text { connected with environment disturbances: } 1 \text {. percentage of the area of land } \\
\text { cover-classes, } 2 \text {. percentage of the area of age-classes of disturbance, } 3 \text {. the } \\
\text { length of roads and the length ditches } \\
\text { Step III } \bullet \text { Environmental variables - variables connected with environment } \\
\text { disturbances (as above); Covariables - variables connected with type of } \\
\text { sediments (as above) }\end{array}$ \\
\hline 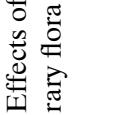 & Options & $\begin{array}{l}\text { centre by species, inter-sample distances, species scores divided by stand- } \\
\text { ard deviation, Monte Carlo test on I axis \& on the trace: reduced model, } \\
\text { unrestricted permutation, number of permutation }=499\end{array}$ \\
\hline
\end{tabular}




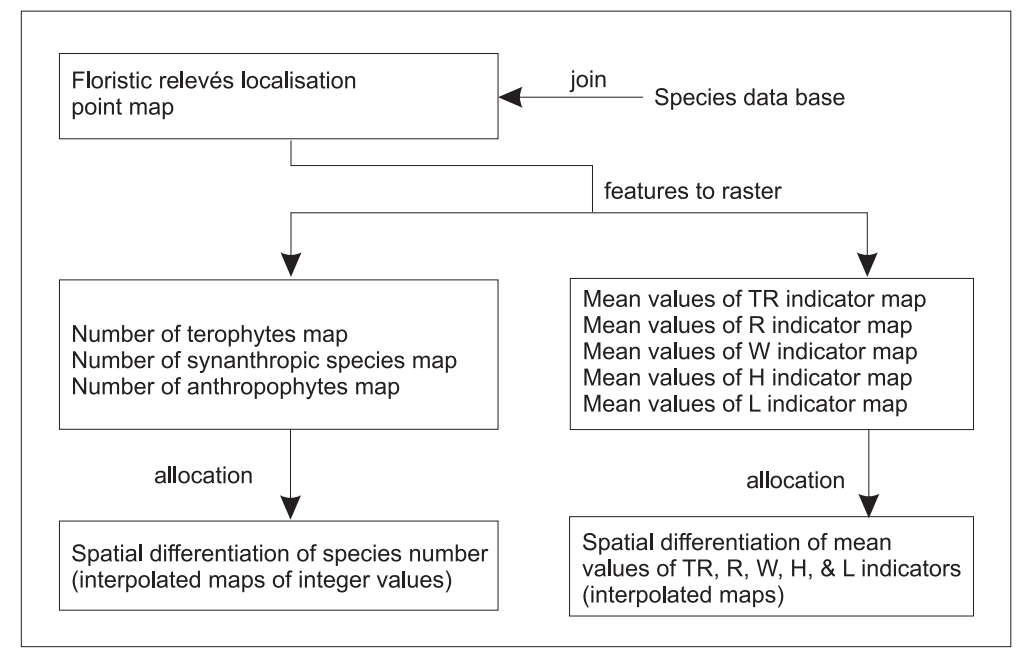

Fig. 4. Cartographic model used for preparation of maps of spatial variation of terophytes, synanthropic species and anthropophytes and mean values of TR, R, W, H and L indicators (in reclass options the new value of attribute of each class was given after hyphen)

and which by anthropogenic factors, the procedure of variance partitioning based on RDA results (see Table 4) was applied (LEPŠ \& ŠMILAUER 2004).

In localities of floristic relevés the following flora features were extracted: the number of species typical to synanthropic habitats, the number of anthropophytes and the number of terophytes. This was then used as the basis for indicator maps preparation (Fig. 4). The analogous procedure was used to elaborate maps of mean values of given ecological indicators (ZARZYCKI et al. 2002): trophy (TR), soil acidity (R), soil moisture (W), light (L) and humus content $(\mathrm{H})$. The calculation of mean values was simplified: for cases in which species occur in a range of values the median one was chosen, and in each floristic relevé the arithmetical mean was calculated. The spatial differentiation of flora features was presented in maps of continuous values elaborated by interpolation technique. The missing values were interpolated with a Euclidean allocation function in which 'No Data' cells were given the value of the closest source cell (ESRI 2001-2002; URBAŃSKI 2001).

\section{RESULTS}

\subsection{Range of changes in flora}

\subsubsection{Species recession}

During the past 198 years in the flora of vascular plants of the Błota Przymorskie Plain and Płutnica Valley 958 taxa were listed, while the contemporary flora of the studied area consists of 808 taxa. Total flora of raised bogs and transitional mire habitat consists of 570 taxa, 
Table 5

Percentage of sociological groups among extinct species

\begin{tabular}{|c|c|c|}
\hline Sociological group* & Number of species & $\begin{array}{c}\text { Percentage } \\
{[\%]}\end{array}$ \\
\hline I & 8 & 8.6 \\
\hline II & 6 & 6.5 \\
\hline III & 8 & 8.6 \\
\hline IV & 6 & 6.5 \\
\hline V & 3 & 3.2 \\
\hline VI & 4 & 4.3 \\
\hline VII & 3 & 3.2 \\
\hline VIII & 8 & 8.6 \\
\hline IX & 7 & 7.5 \\
\hline X & 4 & 4.3 \\
\hline XI & 2 & 2.2 \\
\hline XII & 1 & 1.1 \\
\hline XIII & 3 & 3.2 \\
\hline XIV & 2 & 2.2 \\
\hline XV & 3 & 3.2 \\
\hline XVI & 25 & 26.9 \\
\hline Sum & 93 & 100.0 \\
\hline
\end{tabular}

* - for explanation see Table 2

the total flora of fens - of 927 taxa, while 459 and 792 vascular plant species, respectively, were noted in the contemporary flora.

Among 150 species, which at present were not found in the studied area, 93 (ca 10\% of the whole flora) can be considered as extinct (not recorded since at least 1979). The remaining 57 species were included into the group of undetermined status (common species, probably overlooked during the present survey, species probably incorrectly reported in previous studies, and species which were not permanently established in the flora).

Among locally extinct species (Table 5), a significant proportion have taxa of wide phytosociological amplitude (XVI), aquatic species (I and II), mire species (III and IV) and species of wet meadows (VIIIa).

Species associated with aquatic habitats and habitats of high groundwater level (groups I-VIIIa) comprise $49 \%$ of all extinct species. Detailed analysis of retreat of species from these sociological groups, conducted at the level of syntaxa showed their internal differentiation (Fig. 5):

- in the group of species of oligo- and mesotrophic waters (I) greater losses were noted among taxa of oligotrophic habitats (Littorelletea class -7 species) than in mesotrophic (Utricularietea class -1 species);

- among species of eutrophic waters and springs (II) losses considered almost exclusively representatives of aquatic macrophytes (Potametea class -6 species); 


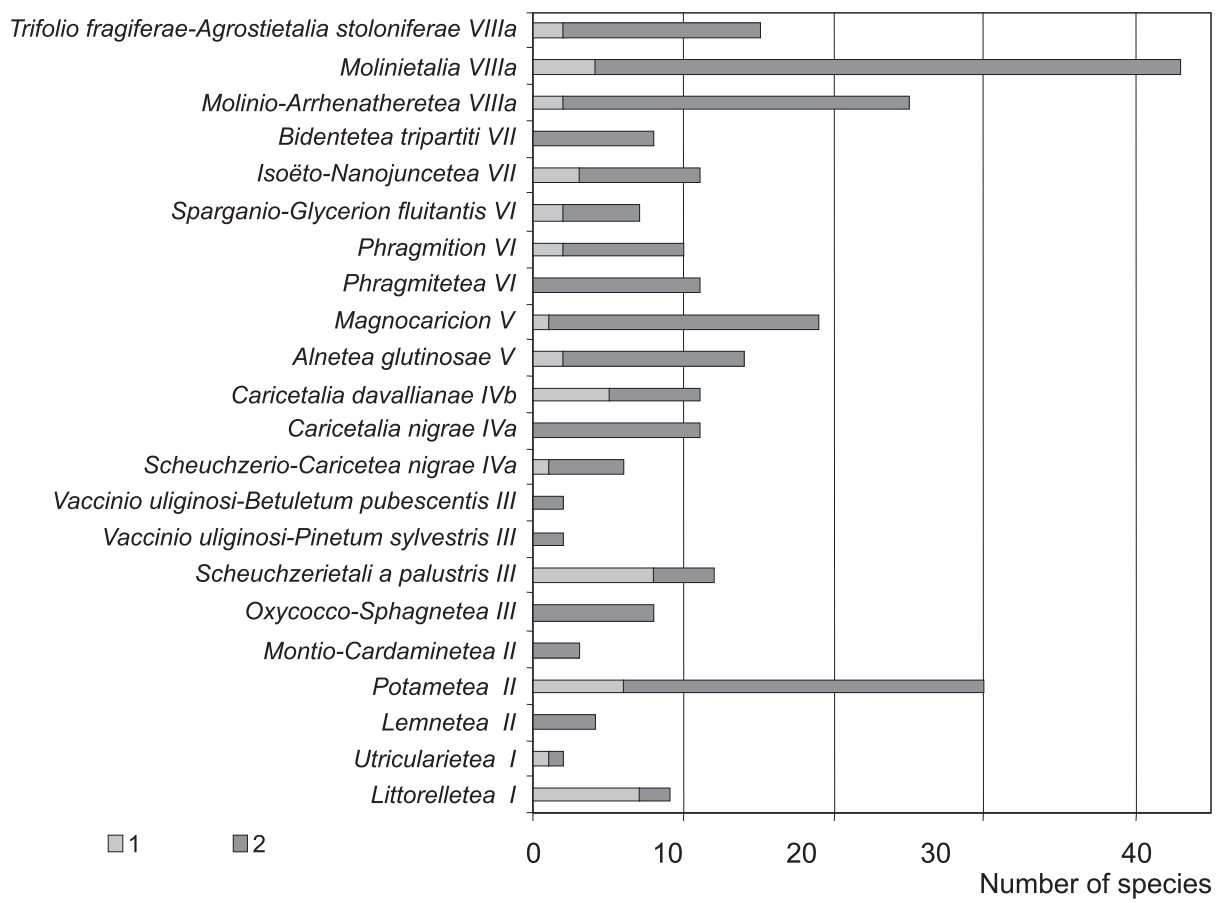

Fig. 5. The number of extinct species (1) versus contemporary living ones (2) in given syntaxa. Beside the name of syntaxa the symbol of sociological group is given (I-VIIIa, explanations see Table 2)

- among species of raised bog complex (III) only those representing order Scheuchzerietalia palustris (8 species), which at a raised bog are an element of hollows, were regarded as locally extinct;

- relatively greatest losses among fen species (IV) were recorded in the group associated with neutral and rich habitats (order Caricetalia davallianae - 5 species);

- in groups of swamp alder forest and sedge communities (V and VI) only a slight decrease in the number of species was recorded (3 and 4 species, respectively);

- retreat in the group of moist mineral soil and silt-covered soil species (VII) consider only species of Isoëto-Nanojuncetea class (3 species);

- locally extinct species connected with wet meadows (VIIIa) belong mostly to communities of purple moor-grass meadows and riparian tall herbs communities (order Molinietalia - 4 species).

Among extinct taxa the greatest proportion have hemicryptophytes (43 species, 46\%), hydro- and helophytes are also well represented (22 species, 24\%) as well as terophytes (11 species, 12\%). In comparison with the biological structure of total flora, low proportion of phanerophytes (only 3 species) drawn attention. The greatest regression occurred in the group of hydro- and helophytes - locations of 22 taxa, which comprise $25.8 \%$ of all aquatic species, were not confirmed.

Disappearance of species considers mainly native taxa. Losses among metaphytes are negligible ( 2 archaeophytes and 1 kenophyte species).

Analysis of disappearance of species within defined investigation periods showed that the greatest losses in flora were stated after 1940 (in 1897-1940 - 63 taxa of vascular plants 
were recorded for the last time, in 1809-1896 - 17 species and in 1941-1979 - only 12 species). High proportion among species recorded for the last time in the second investigation period (1897-1940) have taxa of oligo- and mesotrophic waters (I), bog and fen species (III and IV), species of moist meadows (VIIIa), heathlands (IX), and species of wide phytosociological amplitude (XVI).

\subsubsection{Enrichment of flora and characteristics of contemporary flora}

Number of species in consecutive investigation periods. Because of a lack of complete documentation of flora in particular investigation periods it was not possible to follow all stages of its enrichment with environmentally and geographically alien species. Generally, it can be assumed that since 1809 the number of vascular plant species in the flora of the studied area has gradually increased. In consecutive investigation periods the following numbers of species were noted: 1809-1896 - 327 species; 1897-1940 - 545 species; 19411979 - 366 species (in this period surveys covered only selected parts of the area); 1980 1996 - 619 species; $1997-2004$ - 808 species.

It can be assumed that the rise of number of species in consecutive investigation periods resulted both from real establishment of species and better recognition of flora by botanists.

The total number of species recorded in the studied area is $33 \%$ of flora of vascular plants of Poland, considering that it is recently estimated at 2980 species (MIREK et al. 2002).

Geographic-historical structure of the flora. In the present flora of the studied area, 612 spontaneophytes and 196 anthropophytes occur (Table 6). In the group of species of foreign origin, diaphytes prevail ( 76 species). Their presence is most often connected with accidental bringing of their diaspores with garbage and organic waste. This considers mainly decorative plants, such as e.g. Callistephus chinensis, Salvia viridis and vegetables, e.g. Lycopersicon esculentum. The source of diaspores of diaphytes might be also supplemental food left for wild animals by hunters. Diaphytes occupy also habitats around cottages and along communication paths (e.g. Avena sativa, Raphanus sativus).

Table 6

Percentage of anthropophytes in contemporary flora

\begin{tabular}{|c|c|c|c|}
\hline \multicolumn{2}{|c|}{ Geographic-historical group } & Number of species & $\begin{array}{c}\text { Percentage } \\
{[\%]}\end{array}$ \\
\hline \multicolumn{2}{|c|}{ Spontaneophytes } & 612 & 76 \\
\hline \multicolumn{2}{|c|}{ Archaeophytes } & 61 & 8 \\
\hline \multirow[t]{3}{*}{ Kenophytes } & Epecophytes & 40 & 5 \\
\hline & Hemiagriophytes & 8 & 1 \\
\hline & Holoagriophytes & 11 & 1 \\
\hline \multicolumn{2}{|l|}{ Diaphytes } & 76 & 9 \\
\hline \multicolumn{2}{|l|}{ Sum } & 808 & 100 \\
\hline
\end{tabular}




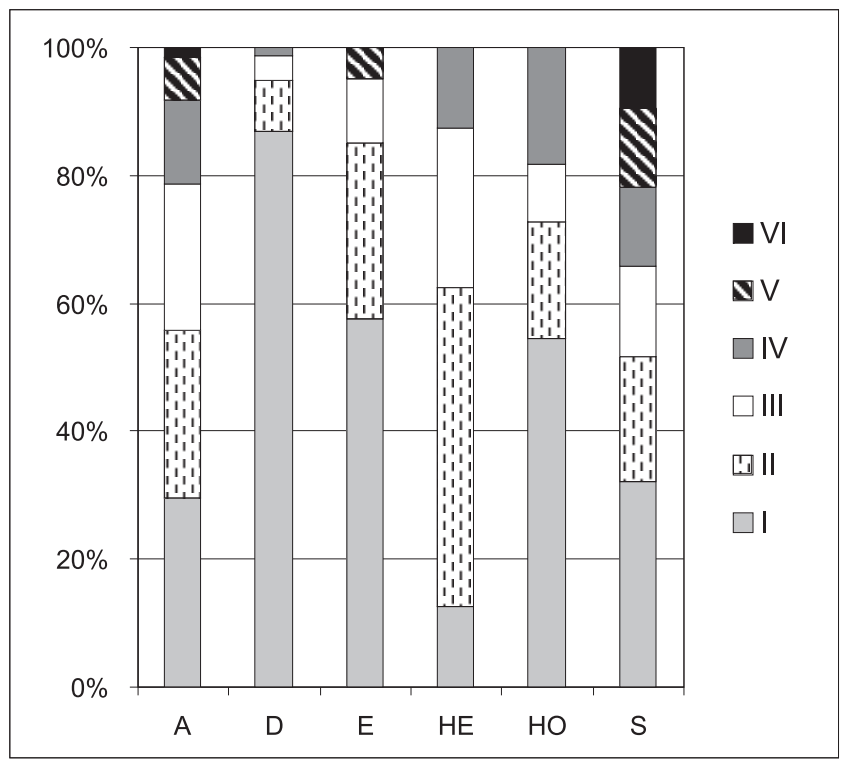

Fig. 6. The frequency of species in given geographic-historical groups I-very rare; II - rare; III - widespread; IV - frequent; V - very frequent; VI - common species; $\mathrm{S}$ - spontaneophytes; A - archaeophytes; D - diaphytes; E - epecophytes; HE - hemiagriophytes; $\mathrm{HO}$ - holoagriophytes

The group of archaeophytes comprises 61 species. They are connected mainly with arable land (e.g. Aphanes arvensis, Bromus secalinus) or with ruderal habitats (e.g. Conium maculatum, Leonurus cardiaca). They are often recorded also at areas of disturbed soil surface, and along drainage ditches.

There are 59 species of kenophytes recorded in the studied area. In majority they are established in synanthropic habitats (40 species of epecophytes, e.g. Bromus carinatus, Echinocystis lobata, Impatiens glandulifera). Semi-natural and natural habitats support $30 \%$ of kenophytes, including 8 species of hemiagriophytes (e.g. Epilobium ciliatum, Lolium multiflorum) and 11 species of holoagriophytes (e.g. Elodea canadensis, Picea abies).

In the group of archaeophytes and spontaneophytes proportion of species of particular frequency classes does not depart substantially from the species frequencies in the total contemporary flora (Fig. 6). More than a half of taxa in these groups are rare and very rare species. Among diaphytes and agriophytes common and very frequent species are completely missing. The total proportion of species from I and II frequency class is the highest among diaphytes (94\%), and among kenophytes it ranges from $62 \%$ (hemiagriophytes) to $84 \%$ (epecophytes).

Sociological structure of the flora. In contemporary flora of the study area, mires taxa (groups III, IVa, IVb) constitute $4.7 \%$ of the total number of species (Table 7). All species associated with high water level, i.e. aquatic, mire and rush plants (groups I-VI) comprise $15.6 \%$ of flora. Taxa of wide sociological amplitude (group XVI) have the greatest proportion of the flora (33\%). Slightly more than $19 \%$ of flora is formed by synanthropic species $(\mathrm{XV})$, among which the most numerous are species of ruderal habitats ( 74 species) and crop land weeds (64 species). Relatively high proportion of flora have meadow species (VIII); in this group species of wet meadows are significantly more numerous (VIIIa $-9.3 \%$ of flora) than species of semi-dry habitats (VIIIb $-3.2 \%$ of flora). A significant proportion $(8.3 \%)$ have also species of rich deciduous forest and shrubs (group XII). 
Table 7

Sociological structure of flora

\begin{tabular}{|c|c|c|}
\hline Sociological group* & Number of species & Percentage [\%] \\
\hline I & 3 & 0.4 \\
\hline II & 31 & 3.8 \\
\hline III & 16 & 2.0 \\
\hline IVa & 16 & 2.0 \\
\hline $\mathrm{IVb}$ & 6 & 0.7 \\
\hline $\mathrm{V}$ & 30 & 3.7 \\
\hline VI & 24 & 3.0 \\
\hline VII & 16 & 2.0 \\
\hline VIIIa & 75 & 9.3 \\
\hline VIIIb & 26 & 3.2 \\
\hline IX & 17 & 2.1 \\
\hline $\mathrm{X}$ & 24 & 3.0 \\
\hline XI & 19 & 2.4 \\
\hline XII & 67 & 8.3 \\
\hline XIII & 16 & 2.0 \\
\hline XIV & 2 & 0.2 \\
\hline XV & 154 & 19.1 \\
\hline XVI & 266 & 32.9 \\
\hline Sum & 808 & 100.0 \\
\hline
\end{tabular}

* - for explanation see Table 2

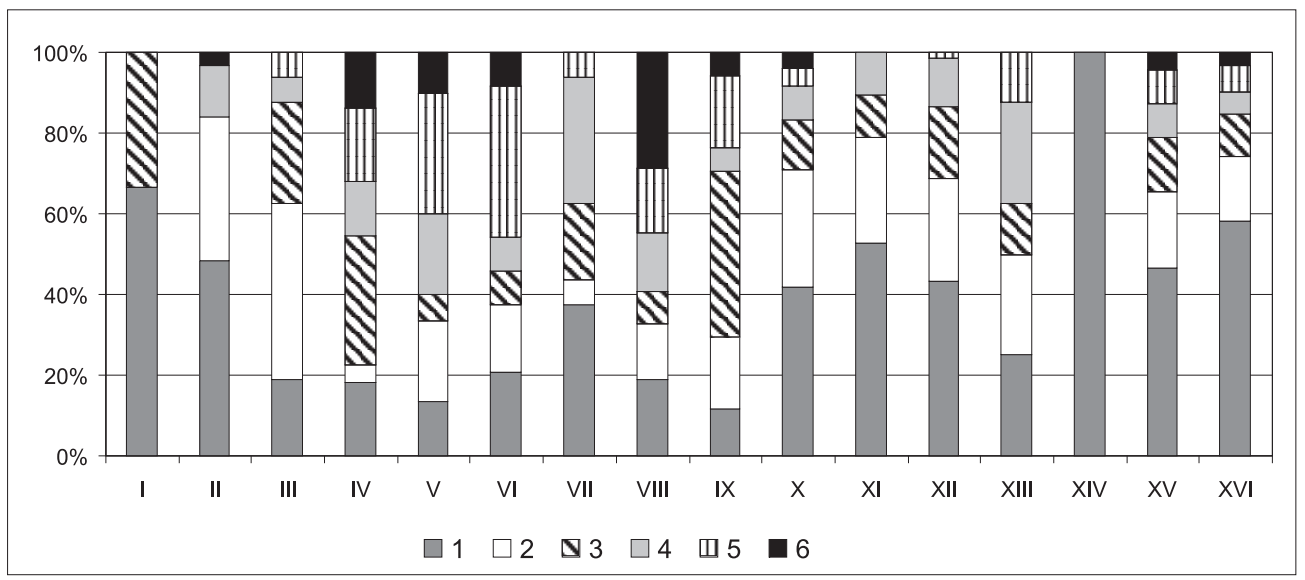

Fig. 7. The frequency of species in given sociological groups

1 - very rare; 2 - rare; 3 - widespread; 4 - frequent; 5 - very frequent; 6 - common species; other symbols see Table 2 
Defined sociological groups of species are differentiated in regard to proportions of frequency classes (Fig. 7). The typical feature of species characteristic of oligo- and mesotrophic waters (I), neutral and rich fens (IVb) and of salty marshes (XIV) is a complete lack of common and very frequent taxa. Very rare and rare species predominate among taxa connected with eutrophic waters (II), raised bogs (III), sandy grasslands (X), termophilous forest-edges and xerothermic grasslands (XI), rich deciduous forests and shrubs (XII), synanthropic habitats (XV), and among taxa with wide sociological amplitude (XVI). Frequent, very frequent and common species are the majority of the group of poor fen species (IVa), swamp alder forest and sedge communities species (V), rushes species (VI) and meadow species (VIII). The group of poor fen species (IVa) draws attention due to the fact that any species of I or II frequency class has been stated in this group.

The majority of defined sociological groups are formed of native species, while taxa of foreign origin play greater role only in groups of species of synanthropic habitats (XV) and of wide sociological amplitude (XVI).

Biological structure of the flora. In contemporary flora of the studied area hemicryptophytes $(41 \%)$ and terophytes $(25 \%)$ have the highest representation. Phanerophytes, geophytes and hydro- and helophytes are $13 \%, 9 \%$ and $8 \%$ of the flora, respectively. The least numerous group are chamaephytes, which comprise $4 \%$ of the flora (Table 8 ).

In comparison with the flora of Poland, perennial plants have much less importance, while phanerophytes, terophytes and chamaephytes have much greater importance. Higher representation of trees and shrubs is connected with expansion of species of foreign origin, which are in majority considered as non-established elements of flora. Abundant occurrence of annual and biannual plants in the studied area is connected mainly with the presence of anthropogenic habitats, such as "islands" of mineral soils, ground roads and arable land. For example, the proportion of terophytes in the flora of the Błota Przymorskie Plain and Płutnica Valley is slightly higher than in the area of the Słowiński National Park, which is only slightly changed by anthropic pressure. Furthermore, it is lower than in the eastern part of the Gnieźnieńskie Lakeland, where arable land is a dominant element of the landscape (Table 8).

Analysis of the spectrum of life forms in determined sociological groups showed that in these groups of species, which can be considered as the natural elements of flora (groups I-VI), hemicryptophytes and hydro- and helophytes prevail, while chamaephytes and

Table 8

Living forms of species in the flora of studied area, flora of Słowiński National Park (PIOTROwSKA et al. 1997), flora of Gnieźnieńskie Lakeland (CHMIEL 1993) and flora of Poland (PAwŁowsKa 1959)

\begin{tabular}{|c|c|c|c|c|c|c|c|}
\hline Living forms & \multicolumn{2}{|c|}{$\begin{array}{c}\text { Błota Przymorskie } \\
\text { Plain and Płutnica } \\
\text { Valley }[\%]\end{array}$} & \multicolumn{2}{|c|}{$\begin{array}{c}\text { Słowiński National } \\
\text { Park [\%] }\end{array}$} & \multicolumn{2}{|c|}{$\begin{array}{l}\text { Gnieźnieńskie } \\
\text { Lakeland [\%] }\end{array}$} & $\begin{array}{c}\text { Poland } \\
{[\%]}\end{array}$ \\
\hline Phanerophytes & \multicolumn{2}{|c|}{13} & \multicolumn{2}{|c|}{12} & \multicolumn{2}{|c|}{10} & 9 \\
\hline Chamaephytes & \multicolumn{2}{|c|}{4} & \multicolumn{2}{|c|}{6} & \multicolumn{2}{|c|}{4} & 2 \\
\hline Hemicryptophytes & 41 & \multirow{3}{*}{58} & 39 & \multirow{3}{*}{59} & 39 & \multirow{3}{*}{59} & \multirow{3}{*}{67} \\
\hline Geophytes & 9 & & 11 & & 13 & & \\
\hline Hydro- and helophytes & 8 & & 9 & & 7 & & \\
\hline Terophytes & \multicolumn{2}{|c|}{25} & \multicolumn{2}{|c|}{23} & \multicolumn{2}{|c|}{27} & 22 \\
\hline
\end{tabular}




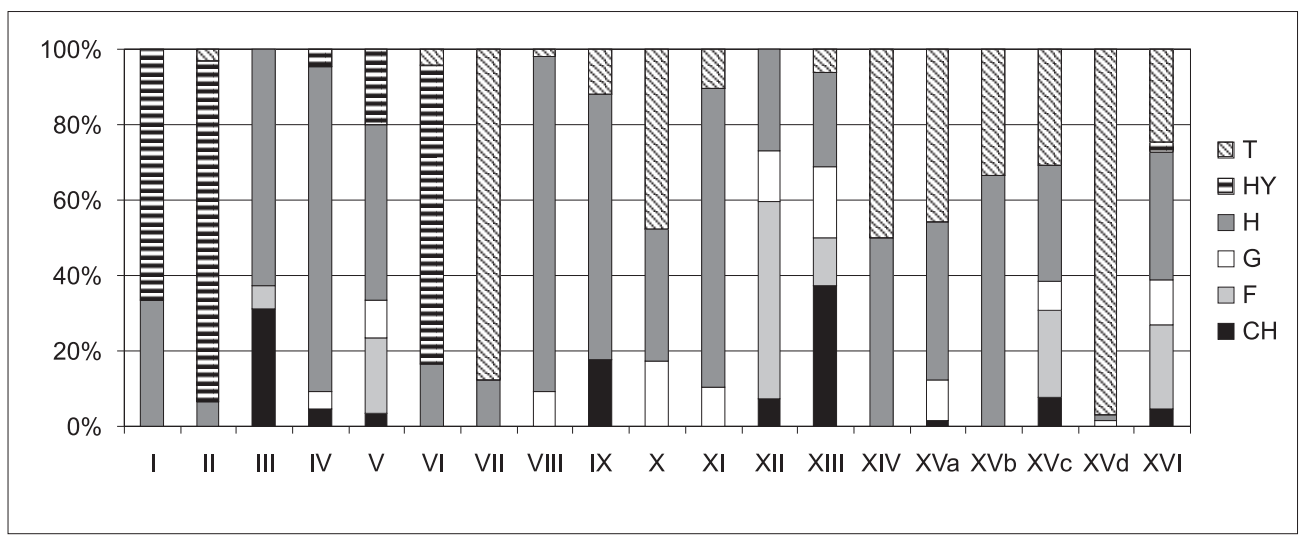

Fig. 8. Percentage of living form group of species in each sociological group

$\mathrm{CH}$ - chamaephytes; HY - hydro- and helophytes; G - geophytes; F - phanerophytes; T - terophytes; H - hemicryptophytes; other symbols see Table 2

phanerophytes are considerably less common, and geophytes or terophytes have only slight representation (Fig. 8). Enrichment of the flora with phanerophytes, geophytes and terophytes species can be considered as an indicator of anthropogenic disturbance to the environment. Geophytes are relatively well represented among species of sandy grasslands (X), forests (XII, XIII) and termophilous forest-edges (XI), while phanerophytes are abundant in the group of taxa of rich deciduous forest or shrubs (XII) and clearings $(\mathrm{XVc})$. Terophytes are numerously represented in the group of species of ruderal habitats (XV), especially of crop land (XVd), moist mineral soils and silt-covered soils (VII) and among sandy grasslands and dunes species (X).

\subsubsection{Dynamic tendencies of selected groups of species}

Apophytism of spontaneophytes. The dynamics of native species is reflected by e.g. their ability to occupy strongly transformed, eu- and polyhemerobic habitats. In this paper this tendency is described as the index of apophytism $\left(\mathrm{I}_{\mathrm{ap}}\right)$.

A lack of tendency to occupy strongly transformed habitats $\left(\mathrm{I}_{\mathrm{ap}}=0\right)$ was stated only in case of 34 taxa (6\% spontaneophytes). Almost $70 \%$ of species from this group are associated with aquatic habitats and habitats of high groundwater level. This considers taxa typical of eutrophic waters (II - e.g. Lemna trisulca, Myriophyllum verticillatum); raised bogs, acid swamp forests and fens (III, IV - e.g. Carex lasiocarpa, Dryopteris dilatata); swamp alder forests and sedges communities ( $\mathrm{V}-$ e.g. Osmunda regalis, Thelypteris palustris); wet meadows (VIIIa - e.g. Carex cespitosa, Cnidium dubium). The remaining taxa, which do not show any tendency of apophytism are associated with forests (XII, XIII - e.g. Ranunculus auricomus, Pyrola minor) or belong to a group of wide sociological amplitude species, e.g. Dactylorhiza maculata, Platanthera bifolia, P. chlorantha.

The most numerous group among native species (225 species, $38 \%$ of spontaneophytes) are taxa of a very low tendency for apophytism $\left(1 \% \leq \mathrm{I}_{\mathrm{ap}} \leq 25 \%\right)$. This group is represented by e.g. species typical of wet meadows (VIIIa - e.g. Achillea ptarmica, Molinia caerulea); 


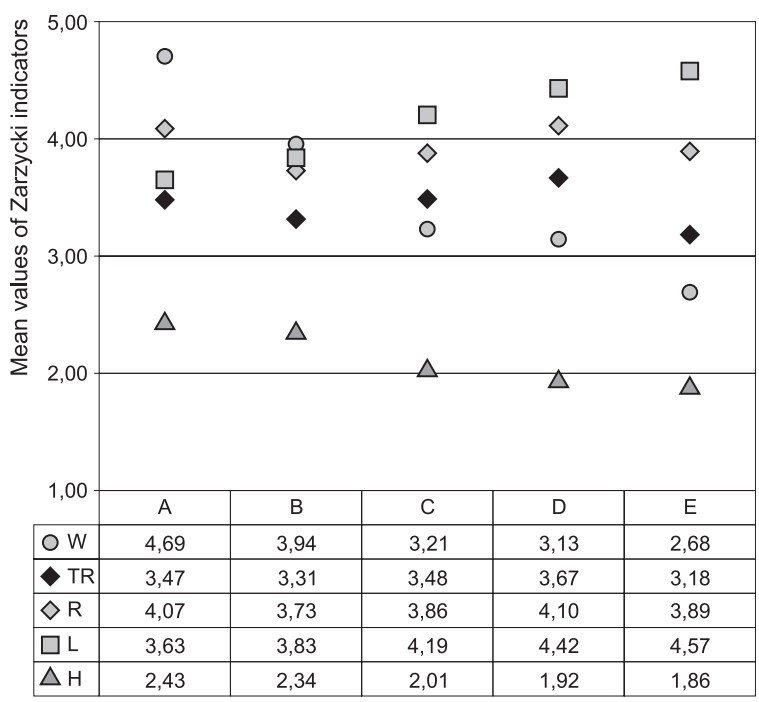

Fig. 9. Mean values of Zarzycki indicators in each apophytism class (A-E)

A $-\mathrm{I}_{\text {ap }}=0 ; \mathrm{B}-1 \% \leq \mathrm{I}_{\text {ap }} \leq 25 \%$; $\mathrm{C}-26 \% \leq \mathrm{I}_{\text {ap }} \leq 50 \% ; \mathrm{D}-51 \% \leq \mathrm{I}_{\text {ap }} \leq 75 \%$; $\mathrm{E}-76 \% \leq \mathrm{I}_{\mathrm{ap}} ; \mathrm{W}-$ soil moisture indicator; TR - trophy indicator; $\mathrm{R}$ - soli acidity indicator; $\mathrm{L}$ - light indicator; $\mathrm{H}$ - humus content indicator

raised bogs and acidophilous swamp forests (III, IV - e.g. Andromeda polifolia, Calamagrostis stricta) and heathlands (IX - e.g. Calluna vulgaris, Viola canina). Some synanthropic species also belong to this class (XV - e.g. Epilobium hirsutum, Eupatorium cannabinum, Urtica dioica).

Among 80 species showing a moderate tendency of apophytism $\left(26 \% \leq \mathrm{I}_{\mathrm{ap}} \leq 50 \%\right)$, which comprise $13 \%$ of spontaneophytes, a relatively high proportion have taxa typical of semidry meadows (VIIIb - e.g. Leontodon autumnalis, Rumex thyrsiflorus); ruderal habitats (XVa - e.g. Calystegia sepium, Rubus caesius); and clearings (XVc - e.g. Calamagrostis epigejos, Senecio sylvaticus).

Species of strong and very strong tendency of apophytism $\left(51 \% \leq \mathrm{I}_{\mathrm{ap}}\right)$ are $7 \%$ of spontaneophytes (44 species). This group is formed e.g. by taxa of ruderal (XVa) and segetal $(\mathrm{XVd})$ habitats, sandy grasslands $(\mathrm{X})$, termophilous forest-edges and xerothermic grasslands (XI), meadows (VIII), moist mineral soils and silt-covered soils (VII) and species of wide sociological amplitude (XVI). Strong tendency to apophytism $\left(51 \% \leq \mathrm{I}_{\mathrm{ap}} \leq 75 \%\right)$ is shown by e.g. Juncus bufonius, Daucus carota, Bromus inermis, Artemisia vulgaris, Galeopsis tetrahit. The following 14 species of spontaneophytes are in great extent associated with eu- and polyhemerobic habitats $\left(76 \% \leq \mathrm{I}_{\mathrm{ap}}\right)$ : Aethusa cynapium, Anchusa arvensis, Arctium minus, Arenaria serpyllifolia, Artemisia campestris, Chenopodium album, Erodium cicutarium, Juncus compressus, Medicago lupulina, Melilotus alba, Poa annua, Potentilla argentea, Spergularia rubra and Trifolium arvense.

Described groups of spontaneophytes have been characterised by the mean values of Zarzycki ecological indicators (ZARZYCKI et al. 2002). Species which do not show any tendency for apophytism $\left(I_{\text {ap }}=0\right)$ are associated with the most humid habitats, of a relatively high humus content and with relatively low light indicator (Fig. 9). The group of taxa showing very strong tendency for apophytism $\left(76 \% \leq \mathrm{I}_{\text {ap }}\right)$ is characterised by the lowest values of moisture, trophy and humus content indicators. These species are adapted to colonise dry, mineral anthropogenic habitats, such as ground roads and arable fields. 
Naturalisation of anthropophytes. Ability of species of foreign origin to invade natural and semi-natural (oligo- and mesohemerobic) habitats was described using naturalisation indicator $\left(I_{\text {nat }}\right)$. In the analysis sporadic species (with 1-10 records) were not considered.

Only one species of foreign origin - Veronica persica was encountered exclusively on euhemerobic habitats $\left(\mathrm{I}_{\text {nat }}=0\right)$.

Relatively high proportion (21 species, $18 \%$ ) among anthropophytes have taxa of weak abilities to occupy oligo- and mesohemerobic habitats $\left(1 \% \leq \mathrm{I}_{\text {nat }} \leq 25 \%\right)$. They are mostly archaeophytes associated with arable fields, e.g. Anagallis arvensis, Anthemis arvensis and ruderal habitats: Descurainia sophia, Malva neglecta.

Anthropophytes of medium tendency to invade natural and slightly transformed habitats $\left(26 \% \leq \mathrm{I}_{\text {nat }} \leq 50 \%\right)$ are also a numerous group (22 species, $\left.18 \%\right)$. Archaeophytes associated with segetal habitats prevail among them, e.g. Apera spica-venti, Lamium purpureum. Taxa of wide sociological amplitude, e.g. Conyza canadensis, Prunus cerasifera, and species of ruderal habitats, e.g. Impatiens glandulifera also belong to this group.

Taxa of strong tendency to naturalisation $\left(51 \% \leq \mathrm{I}_{\text {nat }} \leq 75 \%\right)$ are $5 \%$ of all plants of foreign origin. This group consists of 6 species: kenophytes - Epilobium ciliatum, Anthoxanthum aristatum, Sambucus racemosa, Malus domestica, and archaeophytes - Lamium album and Odontites verna.

The strongest tendency to occupy oligo- and mesohemerobic habitats $\left(76 \% \leq \mathrm{I}_{\text {nat }}\right)$ was shown by 5 species of kenophytes: Elodea canadensis, Lolium multiflorum, Padus serotina, Picea abies and Pyrus communis.

Analysis of the geographic-historical structure of distinguished naturalisation classes indicated that kenophytes showed remarkably stronger tendency to expansion to semi-natural habitats. Archaeophytes were represented mostly by specialised field weeds, and their mean naturalisation index is $25 \%$. Kenophytes have much wider habitat and sociological amplitude and the mean value of the naturalisation index for them is $51 \%$. Comparison of the highest values of naturalisation indicator of older and newer invaders confirmed clearly stronger expansiveness of kenophytes - it is $60 \%$ for archaeophytes (Odontites verna) and $100 \%$ for kenophytes (Elodea canadensis).

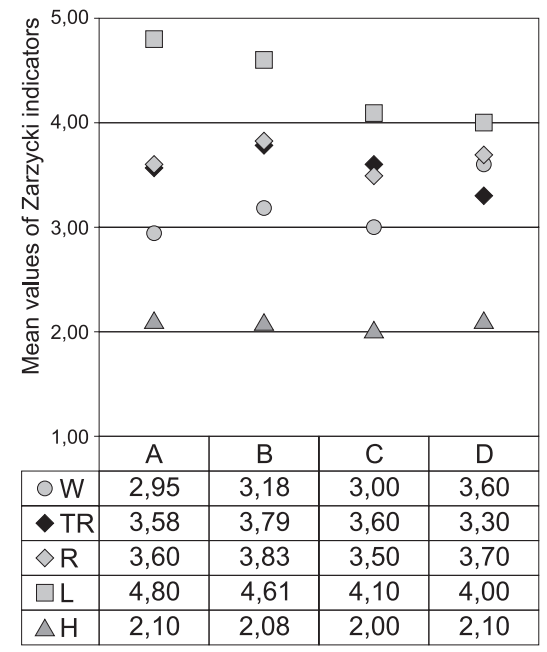

Fig. 10. Mean values of Zarzycki indicators in each naturalisation class (A-D)

A $-1 \% \leq \mathrm{I}_{\text {nat }} \leq 25 \% ; \mathrm{B}-26 \% \leq \mathrm{I}_{\text {nat }} \leq 50 \% ; \mathrm{C}-51 \% \leq \mathrm{I}_{\text {nat }} \leq 75 \%$; $\mathrm{D}-76 \% \leq \mathrm{I}_{\text {nat }} ; \mathrm{W}$ - soil moisture indicator; $\mathrm{TR}$ - trophy indicator; $\mathrm{R}$ - soil acidity indicator; $\mathrm{L}$ - light indicator; $\mathrm{H}$ - humus content indicator 
Analysis of mean values calculated from Zarzycki indicators (ZARZYCKI et al. 2002) for described groups of anthropophytes showed that these species which were the most successful in invading semi-natural habitats had lower light requirements and preferred slightly higher soil moisture than anthropophytes with low values of naturalisation indicator (Fig. 10).

\subsection{Reasons for changes in flora}

\subsubsection{Reconstruction of changes in selected elements of environment}

During recent two hundred years the whole coastal zone, including the studied area, was deeply transformed by human activity. Collected cartographic materials (topographic maps and aerial photographs), literature data and own observations revealed that the main forms of anthropopressure, which affected the stage of the natural environment, were: drainage works and regulation of rivers, meadows and pastures use, agriculture, peat exploitation, settlements, development of road networks, forestry and illegal waste disposal.

Archival topographic maps, which registered the stage of the study area in years 18621875 and 1934-1939 (Topographic map 1889, 1940-1942), and historical and current aerial photographs from 1964 and 1996-1997 allowed reconstructing successive stages of transformation of the environment (Figs 11-14). The analysis consisted of tracing the changes in area of 9 land cover classes (Table 9):

- the main tendency of changes was a gradual decrease of coverage of areas without signs of disturbance and, simoultanously, expansion of farmland and areas covered by woodland and shrub communities;

- from the first studied period farmlands were the dominant element of the landscape; their coverage increased gradually between 1862 and 1964, when it reached more than $50 \mathrm{~km}^{2}$, and currently a slight decrease of its area to $48 \mathrm{~km}^{2}$ was noted;

- areas of peat excavations covered the largest area in 1964; recently their area has decreased due to overgrowing post-exploitation digs with forest communities;

- during the initial period of studies, the coverage of non-disturbed areas was ca $43 \%$, while at present it comprises as little as $4 \%$ of the studied area;

- as the effect of drainage, the coverage of water reservoirs decreased from ca $0.45 \mathrm{~km}^{2}$ to $0.03 \mathrm{~km}^{2}$ between 1862 and 2002;

- during the initial period of studies forests and shrubs covered neglectible area, while at present they cover in total ca $22 \%$ of the area;

- in the 1990s, a significant increase of built-up area was observed, with tenfold incraese of coverage since 1964;

- the coverage of areas where "other disturbances" were stated reached the highest value in 1964, which is associated mainly with extensive fires which occurred in this period.

Based on maps of land cover classes in four consecutive time periods, a synthetic map of the age of disturbances was prepared (Fig. 15). This map shows that more than $80 \%$ of the studied area has been disturbed already in the initial periods of studies, i.e. between 1862 and 1939. Areas disturbed later are mainly small patches located at the edges of raised and transitional mires - changed into arable land or overgrown by shrubs and woodlands after 1939. 
Table 9

Area of land cover classes in given periods of time

\begin{tabular}{|l|c|c|c|c|c|c|c|c|}
\hline \multirow{2}{*}{ Land cover class } & \multicolumn{2}{|c|}{$1862-1875$} & \multicolumn{2}{c|}{$1934-1939$} & \multicolumn{2}{c|}{1964} & \multicolumn{2}{c|}{$1996-1997$} \\
\cline { 2 - 9 } & $\begin{array}{c}\text { area } \\
{\left[\mathrm{km}^{2}\right]}\end{array}$ & $\%$ & $\begin{array}{c}\text { area } \\
{\left[\mathrm{km}^{2}\right]}\end{array}$ & $\%$ & $\begin{array}{c}\text { area } \\
{\left[\mathrm{km}^{2}\right]}\end{array}$ & $\begin{array}{c}\text { area } \\
{\left[\mathrm{km}^{2}\right]}\end{array}$ & $\%$ \\
\hline No signs of disturbance* & 31.89 & 42.97 & 16.30 & 21.97 & 9.61 & 12.95 & 2.96 & 3.99 \\
\hline Pools & 0.45 & 0.60 & 0.27 & 0.37 & 0.17 & 0.24 & 0.03 & 0.04 \\
\hline Forest & 0.43 & 0.58 & 1.46 & 1.97 & 3.41 & 4.60 & 10.92 & 14.71 \\
\hline Shrubs & 0.33 & 0.5 & 1.72 & 2.32 & 4.60 & 6.20 & 5.64 & 7.61 \\
\hline Agricultural land & 38.51 & 51.90 & 50.92 & 68.62 & 51.20 & 69.01 & 48.54 & 65.42 \\
\hline Post-exploitation area & 2.14 & 2.88 & 2.60 & 3.50 & 2.61 & 3.52 & 0.40 & 0.54 \\
\hline Post-exploitation area with shrubs & 0.00 & 0.00 & 0.07 & 0.10 & 1.14 & 1.54 & 1.33 & 1.79 \\
\hline Built-up area & 0.45 & 0.61 & 0.80 & 1.08 & 0.33 & 0.44 & 3.55 & 4.78 \\
\hline Other disturbances & 0.00 & 0.00 & 0.07 & 0.09 & 1.13 & 1.52 & 0.84 & 1.13 \\
\hline Sum & 74.20 & 100.00 & 74.20 & 100.00 & 74.20 & 100.00 & 74.20 & 100.00 \\
\hline
\end{tabular}

* - all areas where any sign of human activity was recognizable on aerial photo

Comparison of the length of all water courses of the studied area in the 19th century (Topographic map 1889, surveyed 1862-1875) and at present (Topographic map 20002002) showed that:

- during last 140 years the length of water courses in the studied area increased threefold and is in total $1080 \mathrm{~km}$ at present;

- the most intensive drainage works were conducted in the Płutnica Valley where the length of water channels increased almost seven times (Fig. 16), as well as on Dębkowskie Meadows, Bielawskie Błota raised bog and in Czarna Wda Valley (the length of water channels increased 4.3 to 5.4 times);

- during the first studied period the densest drainage network was at Karwieńskie Wetlands, where almost $11 \mathrm{~km}$ of drainage channels per $1 \mathrm{~km}^{2}$ was observed; the least drained area was Bielawskie Błoto bog $\left(1.62 \mathrm{~km}\right.$ of channels $\left./ \mathrm{km}^{2}\right)$;

- at present the highest density of channels and ditches occurs at Ląki Dębkowskie Meadows $\left(21.41 \mathrm{~km}\right.$ of ditches $\left./ \mathrm{km}^{2}\right)$ and in the Czarna Wda Valley $\left(18.84 \mathrm{~km}\right.$ of ditches $\left./ \mathrm{km}^{2}\right)$; the lowest relative number of channels is still at Bielawskie Błoto bog (Table 10).

Comparison of the length of roads located within the studied area in years 1862-1875 (Topographic map 1889) and at present (Topographic map 2000-2002) showed that:

- the total length of roads during last 140 years increased almost four times;

- the most intensive development of the communication network was observed in the region of Płutnica Valley, where in the end of the 19th century only one road joining Łebcz and Starzyński Dwór villages existed, while at present the total length of roads is more than $34 \mathrm{~km}$ (the length of roads increased 24 times!);

- both in the first period of studies, and at present, the best developed infrastructure of roads exists at Karwieńskie Wetlands; at present there is $5.3 \mathrm{~km}$ of roads per each $\mathrm{km}^{2}$ (Table 11). 
Table 10

The length of water courses in years 1862-1875 and 2000-2002

\begin{tabular}{|c|c|c|c|c|}
\hline \multirow[t]{2}{*}{ Spatial units (regions) } & \multicolumn{2}{|c|}{$1862-1875$} & \multicolumn{2}{|c|}{ 2000-2002 } \\
\hline & $\begin{array}{c}\text { length } \\
{[\mathrm{km}]}\end{array}$ & $\begin{array}{c}\text { length } / \mathrm{km}^{2} \\
{\left[\mathrm{~km} / \mathrm{km}^{2}\right]}\end{array}$ & $\begin{array}{c}\text { length } \\
{[\mathrm{km}]}\end{array}$ & $\begin{array}{c}\text { length } / \mathrm{km}^{2} \\
{\left[\mathrm{~km} / \mathrm{km}^{2}\right]}\end{array}$ \\
\hline Białogóra region and Wierzchucińskie Bagno bog & 49.15 & 3.38 & 180.98 & 12.45 \\
\hline Piaśnickie Meadows & 23.54 & 4.82 & 72.50 & 14.85 \\
\hline Dębkowskie Meadows & 53.30 & 3.93 & 290.31 & 21.41 \\
\hline Karwieńskie Wetlands and Karwia region & 129.75 & 10.90 & 166.60 & 14.00 \\
\hline Czarna Wda Valley & 30.59 & 4.38 & 131.62 & 18.84 \\
\hline Bielawskie Błoto raised bog & 24.15 & 1.62 & 130.65 & 8.77 \\
\hline Płutnica Valley & 15.57 & 2.09 & 107.58 & 14.45 \\
\hline Sum & 326.04 & 4.39 & 1080.24 & 14.56 \\
\hline
\end{tabular}

Table 11

Length of roads in years 1862-1875 and 2000-2002

\begin{tabular}{|l|c|c|c|c|}
\hline \multirow{2}{*}{ Spatial units (regions) } & \multicolumn{2}{c|}{$1862-1875$} & \multicolumn{2}{c|}{$2000-2002$} \\
\cline { 2 - 5 } & $\begin{array}{c}\text { length } \\
{[\mathrm{km}]}\end{array}$ & $\begin{array}{c}\text { length/km2 } \\
{[\mathrm{km} / \mathrm{km} 2]}\end{array}$ & $\begin{array}{c}\text { length } \\
{[\mathrm{km}]}\end{array}$ & $\begin{array}{c}\text { length/km2 } \\
{[\mathrm{km} / \mathrm{km} 2]}\end{array}$ \\
\hline Białogóra region and Wierzchucińskie Bagno bog & 11.92 & 0.82 & 48.51 & 3.34 \\
Piaśnickie Meadows & 4.69 & 0.96 & 19.63 & 4.02 \\
Dębkowskie Meadows & 18.92 & 1.40 & 51.97 & 3.83 \\
Karwieńskie Wetlands and Karwia region & 19.67 & 1.65 & 63.12 & 5.30 \\
Czarna Wda Valley & 3.20 & 0.46 & 17.62 & 2.52 \\
Bielawskie Błoto raised bog & 15.35 & 1.03 & 51.33 & 3.45 \\
Płutnica Valley & 1.41 & 0.19 & 34.24 & 4.60 \\
\hline Sum & 75.16 & 1.01 & 286.42 & 3.86 \\
\hline
\end{tabular}

Obtained results have to be treated only as rough ones, because neither historic, nor contemporary map do not reflect the entire network of roads.

\subsubsection{Contemporary flora of raised bogs and transitional mires versus flora of fens submitted to different forms of anthropic pressure}

To determine influence of different forms of anthropopressure on contemporary flora in both ecological types of mires, floristic similarity of habitats, shaped by different types of human activity were studied. In the analysis, the number of records of each species in a given type of habitat was considered.

The model of flora changes of studied habitats, obtained from canonical analysis CA, considering first to fourth ordination axes, explains almost $38 \%$ of the total variation of the data (Table 12). Distribution of samples in the ordination space showed that secondary habitats formed at ecologically different types of peatbogs, subjected to the same forms of anthropopressure, show specific floristic individuality (Fig. 17). Habitats that originate from raised bogs and transitional mires are concentrated around low and medium values of the first ordination axis, while habitats located within former fens are concentrated around medium and high values of this axis. Mean values of Zarzycki indicators (ZARZYCKI 


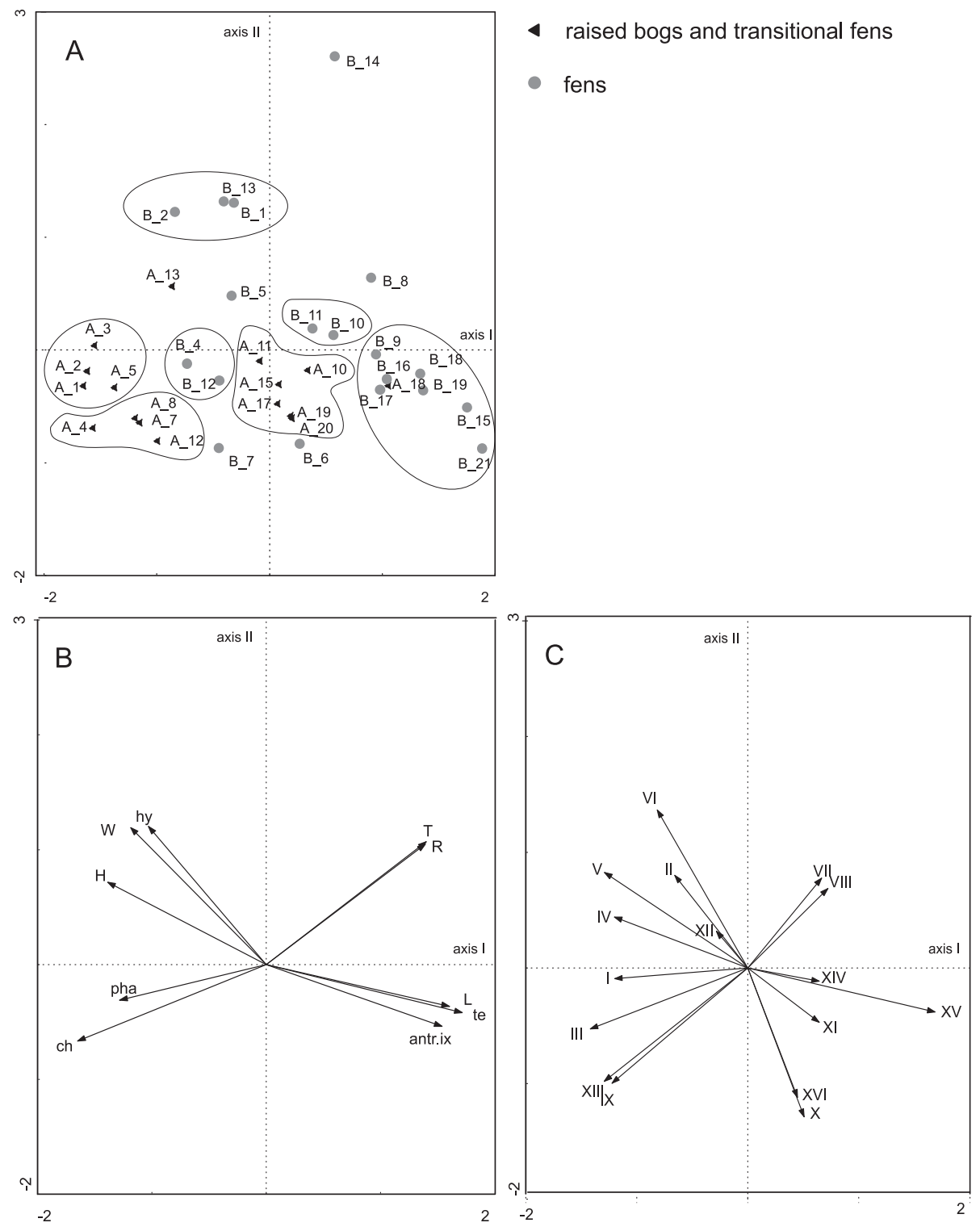

Fig. 17. The model of floristic variability of the habitats under different form of anthropic pressure (CA analysis, inter-sample distance, Hill's scaling)

A - sample plot: A_1-A_20 samples within raised bog/transitional mire habitat; B_1-B_21 - samples within fen habitat (explanations see Table 3); B - supplementary variables: Zarzycki indicators ( $\mathrm{L}$ - light; TR - trophy; $\mathrm{R}$ - acidity; W - moisture; $\mathrm{H}$ - humus content); living forms (pha - phanerophytes; ch - chamaephytes; hy - hydro- i helophytes; te - terophytes); antr.ix - anthropophytisation index; $\mathrm{C}$ - supplementary variables: sociological groups (explanation see Table 2)

et al. 2002), calculated for each type of habitat, were used in the analysis as supplementary variables. Their passive projection on the diagram allowed to determine that the main gradient of variation (axis I) was associated with light availability (L), trophy, (TR), acidity 
Table 12

Results of correspondent analysis CA (inter-sample distance, Hill's scaling) on floristic variability in habitats influenced by different forms of human pressure

\begin{tabular}{|l|c|c|c|c|r|}
\hline \multicolumn{1}{|c|}{ Axes } & I & II & III & IV & Total inertia \\
\hline Eigenvalues & 0.500 & 0.366 & 0.313 & 0.265 & \multirow{3}{*}{3.814} \\
\hline Cumulative percentage variance of species data & 13.1 & 22.7 & 30.9 & 37.9 & 3.814 \\
\hline Sum of eigenvalues & \multicolumn{5}{|r}{} \\
\hline
\end{tabular}

Table 13

Inter-set correlation between chosen variables and ordination axes

\begin{tabular}{|c|l|c|c|}
\hline \multicolumn{2}{|c|}{ Supplementary variables } & \multicolumn{2}{c|}{ Inter-set correlation } \\
\hline \multirow{2}{*}{ Symbol } & \multicolumn{1}{|c|}{ Explanation } & I axis & II axis \\
\hline L & light indicator & 0.8148 & -0.1920 \\
\hline RR & trophic indicator & 0.7110 & 0.5642 \\
\hline R & acidity indicator & 0.7073 & 0.5540 \\
\hline H & humus content indicator & -0.7059 & 0.3783 \\
\hline W & moisture indicator & -0.6035 & 0.6297 \\
\hline
\end{tabular}

(R) and humus content in the substratum $(\mathrm{H})$, while axis II reflects mainly the variety of moisture (W) (Table 13).

In the group of habitats associated with raised bogs and transitional mires, the following rules were stated:

- habitats formed by peat exploitation (A_2), terrestrialized pools (A_3) and shrubs (A_5) developing due to drainage, in terms of species composition of flora are close to natural habitats (A_1); their flora indicates low trophy, significant acidity of the substratum, moderate humidity and humus content; these are habitats of the highest percentage of species typical of oligotrophic waters (I) and raised bogs (II);

- similar floristic composition occurs in habitats disturbed by forestry (A_12) and in woodlands (A_4), heathlands (A_7) and burnt places (A_8) formed as a consequence of drainage; their flora closely resembles flora of natural habitats (A_1) considering indicators of trophy and acidity, but it has lower humus content and humidity of substratum; high proportion of chamaephytes as well as species typical of raised bogs (III), heathlands (IX), pine forests and acid oak forest species (XIII) are distinctive of these habitats;

- flora of habitats formed by hay meadow farming (A_10, A_11), agriculture (A_15), development of transport (A_17) and disturbance to soil cover (A_19, A_20) departs remarkably from the flora of the non-disturbed habitats, especially considering indicators of trophy and acidity, which reach much higher values there; this group is internally diverse in respect of the gradient of humidity, humus content and the percentage of anthropophytes; sociological structure of flora of these habitats is distinguished by high proportion of sandy grassland species $(\mathrm{X})$ and taxa of a wide phytosociological scale (XVI);

- flora of drainage ditches and their embankments (A_13) is characterised by a significant proportion of hydro- and helophytes (HY), including species of water habitats (II), sedges and rushes (V, VI) and species typical of fens (IV); mean values of Zarzycki indicators showed their relatively high trophy and acidity; 
- waste dumps (A_18) do not show any relation to the rest of habitats formed in raised bogs and transitional mires, but highly resemble disturbed habitats of fens; flora of waste dumps is characterised by very low moisture of substratum, high trophy and acidity, high values of light index; high proportion of terophytes, species of synanthropic habitats $(\mathrm{XV})$ and high values of anthropophytisation index are also distinctive.

Considering habitats of fens, it was established that:

- undisturbed habitats (B_1) as well as habitats connected with peat exploitation (B_2) and development of drainage systems (B_13) have similar flora, which shows mainly high moisture of substratum and humus content; their flora is characterised by a significant proportion of hydro- and helophytes, species typical of rushes (VI), alder forests (V), eutrophic waters (II) and fens (IV);

- lower values of the moisture indicator and of humus content are reached by shrub communities, which develop in the effect of drainage works (B_5);

- flora of forest habitats (B_4) and trees plantations (B_12) is characterised by significantly lower value of moisture index than flora of non-disturbed habitats (B_1), and considering its low mean values of trophy and acidity indices it resembles habitats of raised bogs and transitional mires;

- the lowest values of trophy and acidity indicators were noted in habitats of dry heathlands (B_7), which are closed to heathlands of oligotrophic habitats (A_7), but lower moisture of the substratum and lower humus content are the differentiating factors;

- flora of sandy grasslands (B_6), formed on most drained parts of the area, indicates moderate trophy and acidity of these habitats and very low moisture and humus content; it resembles flora of the driest habitats of raised bogs and transitional mires (A_19, A_20, A_17) in this respect as well as in its similar sociological structure;

- habitats shaped by hay meadow farming or grazing (B_10, B_11) differ, by having slightly higher trophy and acidity, from habitats of raised bogs formed by the same type of the land use (A_10, A_11); their flora is characterised by the relatively high participation of meadow species (VIII) and species of silt-covered soils (VII);

- the group of the most disturbed habitats is characterised by the lowest values in the gradient of humidity and humus content, and the highest values of light indicator; their flora has the highest anthropophytisation index, great proportion of terophytes and of synanthropic species (XV); this group consists of intensively used meadows (B_9), human settlements (B_16), roads (B_17), waste dumps (B_18), habitats with mineral disposal (B_19), arable fields (B_15) and artificial surfaces (B_21);

- habitats formed on the banks of regulated rivers (B_14), which have the greatest values of trophy and acidity of substratum and with the high index of humidity, differ significantly from other habitats.

\subsubsection{Flora of sample plots and its relation to selected features of natural environment}

To investigate relations between floristic composition of sample plots and features of the environment, indirect (PCA) and direct (RDA) methods of analyses were used.

The model of floristic variation of sample squares obtained from the principal component analysis PCA, considering first to fourth ordination axes, explained almost $25 \%$ of 
Table 14

Results of principal component analysis PCA (inter-sample distance, centre by species) on floristic variability of sample fields

\begin{tabular}{|l|c|c|c|c|r|}
\hline \multicolumn{1}{|c|}{ Axes } & I & II & III & IV & Total inertia \\
\hline Eigenvalues & 0.100 & 0.062 & 0.051 & 0.033 & \multirow{2}{*}{1.000} \\
\hline Cumulative percentage variance of species data & 10.0 & 16.2 & 21.3 & 24.6 & 1.000 \\
\hline Sum of all Eigenvalues & \multicolumn{5}{|r}{} \\
\hline
\end{tabular}

Table 15

Inter-set correlation between chosen variables and ordination axes

\begin{tabular}{|c|c|c|c|c|c|}
\hline \multicolumn{3}{|c|}{ Supplementary variables } & \multicolumn{3}{|c|}{ Inter-set correlation } \\
\hline Symbol & & Explanation & I axis & II axis & III axis \\
\hline n.sp & \multicolumn{2}{|c|}{ number of species } & -0.9693 & 0.1205 & 0.1531 \\
\hline n.K & \multicolumn{2}{|c|}{ number of kenophytes } & -0.5052 & 0.2037 & 0.5844 \\
\hline$\% \mathrm{~A}$ & \multicolumn{2}{|c|}{ percentage of archaeophytes } & 0.0275 & 0.1442 & 0.7503 \\
\hline$\% \mathrm{~K}$ & \multicolumn{2}{|c|}{ percentage of kenophytes } & -0.0834 & 0.2147 & 0.6340 \\
\hline$\%$ bog & \multicolumn{2}{|c|}{ percentage of bog/transition mire area } & 0.0565 & 0.5586 & -0.1503 \\
\hline $\mathrm{R}$ & \multirow{5}{*}{ 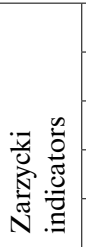 } & acidity & -0.0423 & -0.8020 & 0.1983 \\
\hline $\mathrm{TR}$ & & trophic & 0.0499 & -0.8024 & 0.1808 \\
\hline $\mathrm{W}$ & & moisture & -0.1032 & -0.6134 & -0.5256 \\
\hline $\mathrm{H}$ & & humus content & -0.1075 & -0.3442 & -0.7107 \\
\hline $\mathrm{L}$ & & light & 0.1686 & -0.1400 & 0.7208 \\
\hline mead+past & \multirow{3}{*}{ 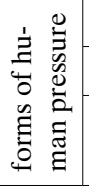 } & hay-meadow farming \& grazing & -0.6469 & -0.3435 & 0.1773 \\
\hline drain & & creating of drainage system & -0.7431 & -0.1991 & 0.1477 \\
\hline transp & & transport & -0.6415 & 0.2377 & 0.0718 \\
\hline I & \multirow{7}{*}{\multicolumn{2}{|c|}{$\begin{array}{l}\text { percentage of sociological groups } \\
\text { (see Table 2) }\end{array}$}} & 0.2471 & 0.5209 & -0.1395 \\
\hline II & & & -0.1936 & -0.5060 & 0.0807 \\
\hline III & & & 0.1767 & 0.6223 & -0.2645 \\
\hline IV & & & -0.2715 & 0.0933 & -0.5280 \\
\hline $\mathrm{V}$ & & & -0.2674 & -0.3574 & -0.6087 \\
\hline XIII & & & -0.0159 & 0.7146 & -0.4260 \\
\hline XV & & & 0.1148 & 0.0656 & 0.7057 \\
\hline hy & \multicolumn{2}{|c|}{ percentage of hydro- and helophytes } & -0.0582 & -0.7100 & -0.1997 \\
\hline te & \multicolumn{2}{|c|}{ percentage of terophytes } & -0.0212 & 0.2030 & 0.8186 \\
\hline forest & \multicolumn{2}{|c|}{ percentage of the forest area } & -0.0220 & 0.5634 & -0.3075 \\
\hline agr & \multicolumn{2}{|c|}{ percentage of the agricultural land area } & -0.0721 & -0.6177 & 0.1133 \\
\hline w1 & \multicolumn{2}{|c|}{$\begin{array}{l}\text { percentage of classes of the age of distur- } \\
\text { bances - area disturbed since } 1862-1875\end{array}$} & 0.1003 & -0.5133 & 0.2737 \\
\hline w4 & \multicolumn{2}{|c|}{$\begin{array}{l}\text { percentage of classes of the age of distur- } \\
\text { bances - area disturbed since 1996-1997 }\end{array}$} & 0.0598 & 0.7094 & -0.0208 \\
\hline
\end{tabular}




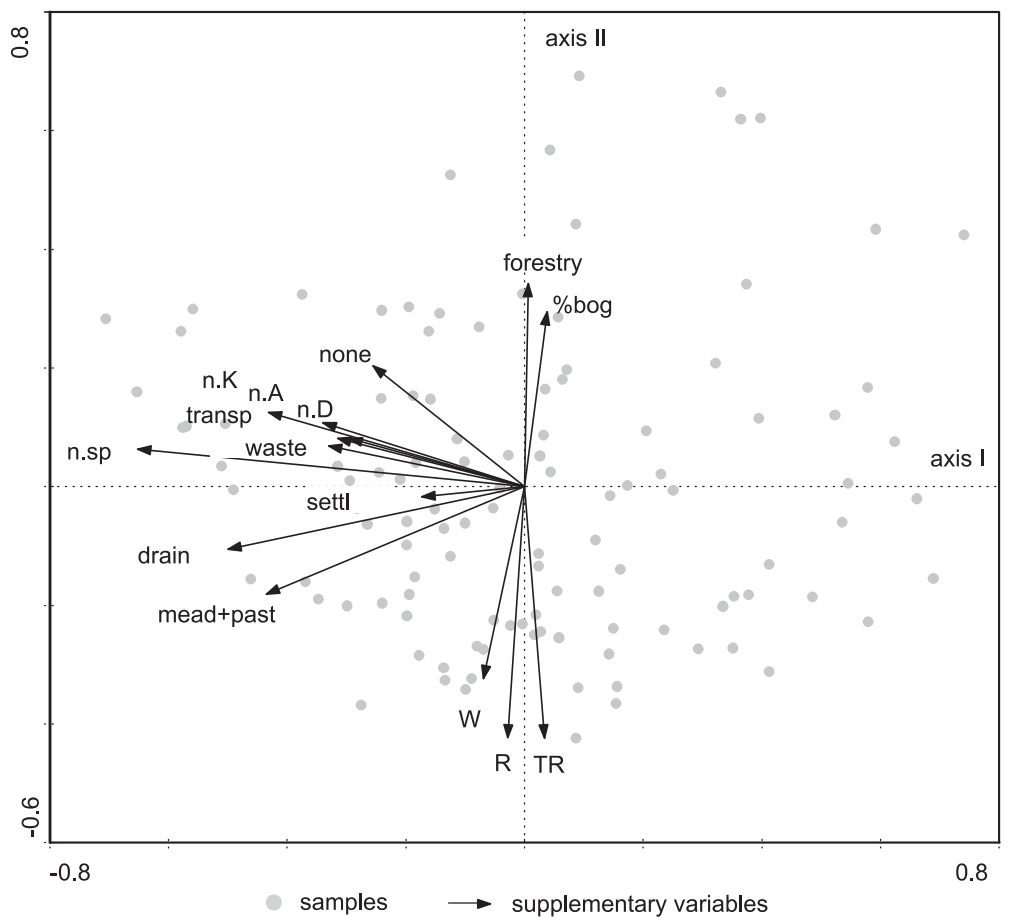

Fig. 18. Model of floristic variability of sample plots (PCA analysis, inter sample distances, centre by species) displaying two first ordination axes

Arrows represent supplementary variables: $n . s p$ - number of species; forms of anthropic pressure (transp - transport; waste - waste disposal; settl - settlement; drain - creating and conservation of drainage system; mead + past - hay-meadow farming and grazing; none - no anthropic pressure); geographic-historical groups (n.A - number of archaeophytes; n.K - number of kenophytes; n.D - number of diaphytes); Zarzycki indicators (W - soil moisture; R - acidity; TR - trophy); \%bog - percentage of raised bog/transitional mire habitat

the total variation in the data set (Table 14). Eigenvalues of the axes showed that the first three ordination axes had the greatest input in the explaining of variation in the analysed data set. Based on that, and by including supplementary variables into the model, it was revealed that the most important features which distinguish the flora of squares are: floristic richness (I axis), indicators of acidity and trophy of substratum (II axis), proportion of terophytes, archaeophytes and indicators of light and humus content (III axis) (Table 15).

The following relations between particular variables were stated (Table 16, Fig. 18):

- the number of species is positively correlated with the intensity of such forms of anthropic pressure as: creating the network of drainage channels, hay meadow farming and grazing, transport and waste discharge;

- proportion of raised bog species (III), oligotrophic water species (I) and heathlands species (IX) is positively correlated with the area covered by raised bogs and transitional mires and with the proportion of the post-exploitation areas;

- proportion of species typical of raised bogs (III), oligotrophic waters (I), heathlands (IX) and pine and acid oak forests (XIII) is the highest in squares with relatively recent disturbances, i.e. disturbed between 1964 and 1997 (w4); at the same time the propor- 
Table 16

Correlation between chosen variables (PCA analysis)

\begin{tabular}{|c|c|c|}
\hline Variable 1 & Variable 2 & Correlation coefficient $(\mathrm{r})$ \\
\hline Number of species & transport* & 0.6851 \\
\hline Number of species & hay-meadow farming and grazing* & 0.6038 \\
\hline Number of species & creating of drainage system* & 0.7050 \\
\hline Number of species & waste disposal* & 0.5620 \\
\hline Number of diaphytes & waste disposal* & 0.5022 \\
\hline Number of kenophytes & waste disposal* & 0.5152 \\
\hline Number of kenophytes & settlement* & 0.5682 \\
\hline Percentage of kenophytes & built-up area** & 0.5471 \\
\hline Percentage of kenophytes & roads length index & 0.5423 \\
\hline Percentage of kenophytes & $\mathrm{H}$ & -0.5675 \\
\hline Percentage of kenophytes & $\mathrm{W}$ & -0.5438 \\
\hline Percentage of archaeophytes & $\mathrm{L}$ & 0.6737 \\
\hline Percentage of archaeophytes & $\mathrm{H}$ & -0.7301 \\
\hline Percentage of archaeophytes & $\mathrm{W}$ & -0.6282 \\
\hline I & \%bog & 0.6183 \\
\hline I & post-exploitation area** & 0.5868 \\
\hline I & w4 & 0.5592 \\
\hline III & $\%$ bog & 0.7238 \\
\hline III & post-exploitation area** & 0.6709 \\
\hline III & w1 & -0.5035 \\
\hline III & w4 & 0.6966 \\
\hline IX & \%bog & 0.5862 \\
\hline IX & post-exploitation area** & 0.5700 \\
\hline IX & w1 & -0.5251 \\
\hline IX & w4 & 0.5710 \\
\hline XIII & w4 & 0.5138 \\
\hline Percentage of terophytes & $\mathrm{L}$ & 0.7699 \\
\hline Percentage of terophytes & $\mathrm{H}$ & 0.7699 \\
\hline Percentage of terophytes & $\mathrm{W}$ & -0.6686 \\
\hline Percentage of helo- and hydrophytes & TR & 0.5612 \\
\hline Percentage of helo- and hydrophytes & $\mathrm{R}$ & 0.6107 \\
\hline Percentage of chamaephytes & $\%$ bog & 0.6125 \\
\hline Percentage of chamaephytes & post-exploitation area** & 0.6730 \\
\hline$\%$ bog & no signs of disturbances** & 0.5598 \\
\hline$\%$ bog & post-exploitation area with shrubs** & 0.5315 \\
\hline$\%$ bog & other disturbances** & 0.5249 \\
\hline$\%$ bog & w4 & 0.7780 \\
\hline
\end{tabular}

* - number of relevés made in habitats influenced by given form of human pressure; **percentage of land cover classes area; I-XIII - percentage of sociological groups (see Table 2); H, W, L, R, TR - Zarzycki indicators, w1 percentage area disturbed since 1862-1875; w4 - percentage area disturbed since 1996-1997; \%bog - percentage of raised bog/transition mire habitat 


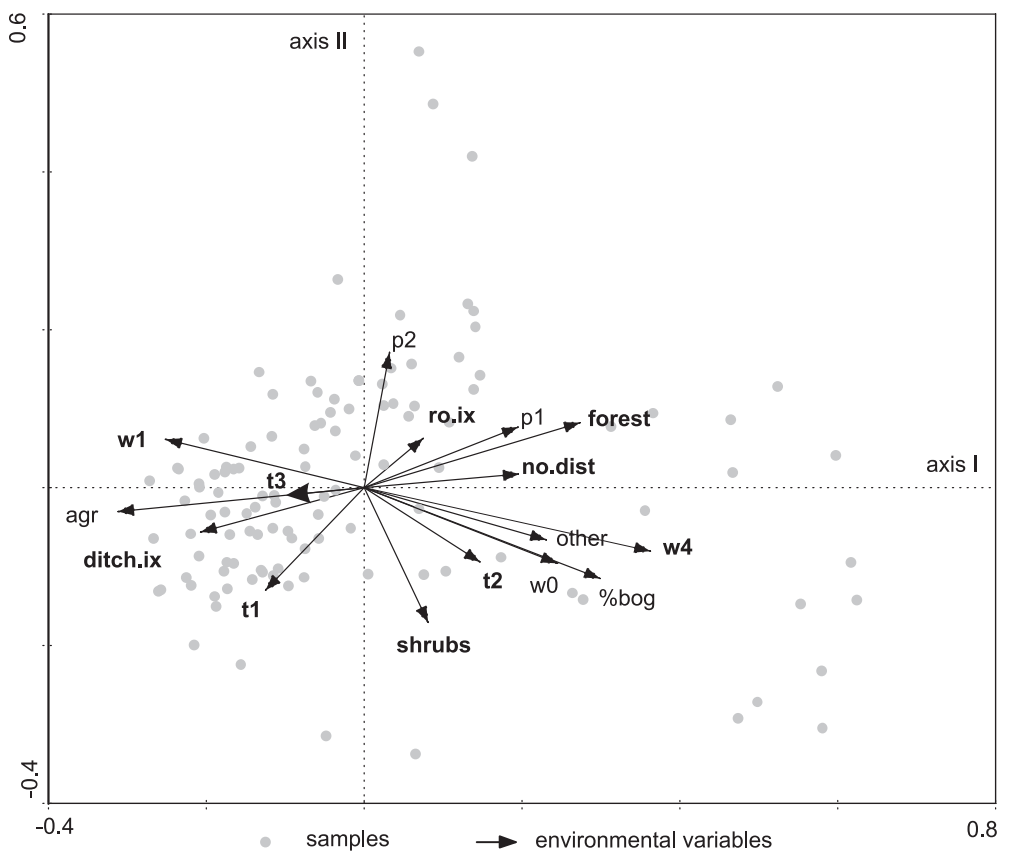

Fig. 19. Sample ordination plot (RDA analysis, inter-sample distances, centre by species). The statistically significant variables are bold (see Table 30)

Environmental variables - natural: \%bog - percentage of raised bog/transitional mire habitat; geological deposits ( $\mathrm{t} 1$ - peat; $\mathrm{t} 2$ - peat on loam, clay or gyttja; $\mathrm{t} 3$ - peat on sand or sand with humus; $\mathrm{p} 1$ - sand; $\mathrm{p} 2$ - sand with humus). Environmental variables - anthropogenic: percentage of land cover class area (no.dist - no disturbances; agr - agricultural land; other - other disturbances); percentage of classes of the age of disturbances (w0 - no disturbances; w1 - area disturbed since 1862-1875; w4 - area disturbed since 1996-1997); ro.ix - roads' length index; ditch.ix - ditches' length index

tion of raised bog species and heathlands species is negatively correlated with the area with oldest disturbances;

- proportion of kenophytes in flora is positively correlated with the area of human settlements and the length of roads; kenophytes and archaeophytes inhabit squares of a relatively low moisture and humus content, while archaeophytes require high light availability; the number of kenophytes and diaphytes is positively correlated with the intensity of waste disposing;

- the greatest proportion of terophytes in flora was recorded in squares of a relatively low moisture, low humus content and high values of light indicator; hydro- and helophytes prefer habitats of high trophy and acidity, while chamaephytes are associated with raised bog habitats, especially with post-exploited areas;

- habitats of raised bogs are distinguished by a relatively large coverage of areas with no signs of disturbance, post-exploitation areas with shrubs, or "other disturbances" (connected mainly with extensive fires occurring in the effect of desiccation of the area);

- positive correlation between the area of raised bogs and the highest age class of disturbances indicates that these habitats underwent anthropogenic change relatively late.

The model of variation of flora of studied squares (Fig. 19) obtained from the RDA analysis explains almost $27 \%$ of the total variation in the dataset (Table 17). First four canonical 
Table 17

Results of redundancy analysis RDA (inter-sample distance, centre by species) on floristic variability of sample plots

\begin{tabular}{|c|c|c|c|c|c|}
\hline Axes & I & II & III & IV & Total inertia \\
\hline Eigenvalues & 0.050 & 0.042 & 0.024 & 0.021 & \multirow[t]{3}{*}{1.000} \\
\hline Species-environment correlations & 0.906 & 0.752 & 0.715 & 0.824 & \\
\hline Cumulative percentage variance of species data & 5.0 & 9.1 & 11.6 & 13.6 & \\
\hline $\begin{array}{l}\text { Cumulative percentage variance of species-environment } \\
\text { relation }\end{array}$ & 18.4 & 34.0 & 43.0 & 50.8 & \\
\hline Sum of all Eigenvalues & \multicolumn{5}{|c|}{1.000} \\
\hline Sum of all canonical Eigenvalues & \multicolumn{5}{|c|}{0.269} \\
\hline
\end{tabular}

Table 18

Results of Monte Carlo test on first axis and on trace, as well as on environmental variables

\begin{tabular}{|c|c|c|c|c|c|}
\hline & Item tested & $\mathrm{F}$ & $\mathrm{p}$ & \multicolumn{2}{|c|}{$\begin{array}{c}\text { Variance explained } \\
{[\%]}\end{array}$} \\
\hline & I axis & 4.844 & 0.002 & \multicolumn{2}{|l|}{5.0} \\
\hline & Trace & 1.627 & 0.002 & \multicolumn{2}{|l|}{26.9} \\
\hline \multirow{10}{*}{$\frac{\frac{\tilde{U}}{0}}{\frac{\vec{\sigma}}{\vec{J}}}$} & w4 & 4.706 & 0.002 & 4 & \multirow{10}{*}{ 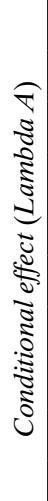 } \\
\hline & $\mathrm{t} 1$ & 2.621 & 0.002 & 2 & \\
\hline & forest* & 2.462 & 0.002 & 2 & \\
\hline & ro.ix & 1.898 & 0.006 & 2 & \\
\hline & w1 & 1.680 & 0.006 & 1 & \\
\hline & ditch.ix & 1.634 & 0.012 & 1 & \\
\hline & $\mathrm{t} 2$ & 1.657 & 0.002 & 1 & \\
\hline & shrubs* & 1.516 & 0.032 & 1 & \\
\hline & no signs of disturbances* & 1.547 & 0.014 & 1 & \\
\hline & $\mathrm{t} 3$ & 1.437 & 0.022 & 1 & \\
\hline
\end{tabular}

* - percentage of land cover classes area; w1 - percentage of the area disturbed since 1862-1875; w4 - percentage of the area disturbed since 1996-1997; ro.ix - length of roads per $1 \mathrm{~km}^{2}$; ditch.ix - length of ditches per $1 \mathrm{~km}^{2}$; $\mathrm{t} 1$ - percentage of peat deposits; $\mathrm{t} 2$ - percentage of peat on loam, clay or gyttja deposits; $\mathrm{t} 3$ - percentage of peat on sand or sand with humus deposits

axes, with very high species-environment correlation, explain jointly $13.6 \%$ of the variation. Statistical significance of the model and of the first canonical axis was confirmed by the Monte Carlo test (Table 18). In the procedure of forward selection of variables it was established that the most important environmental factors included in the analysis were: the age of disturbances, in particular - the coverage of the class of the most recent disturbances (w4), the type of geological deposits - coverage of peat (t1), coverage of forests and the length of roads per $1 \mathrm{~km}^{2}$ (ro.ix). 


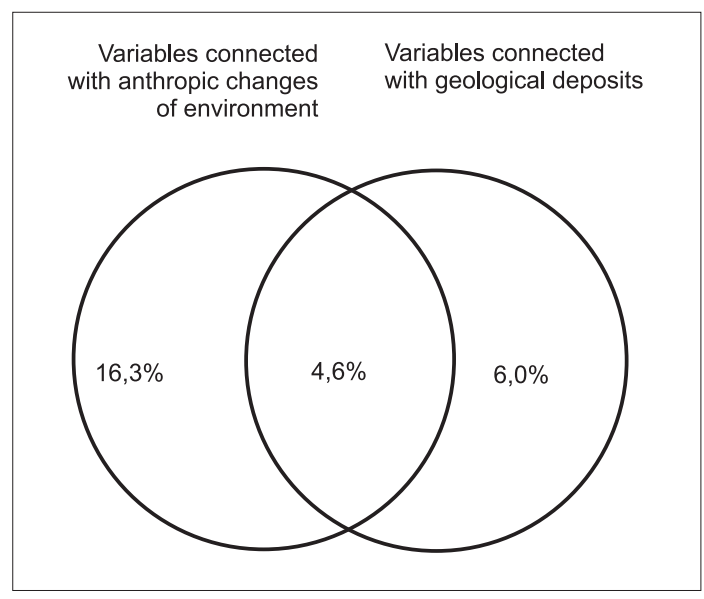

Fig. 20. Variance partitioning based on RDA analysis results

In the effect of the procedure of variance partitioning, performed on the basis of RDA, it was stated that analysed anthropogenic factors have greater explanatory power than factors connected with the geological character of the substratum. The group of variables of an anthropogenic character, which includes the percentage of the land cover classes, the index of roads' length, the length of drainage channels and the age of disturbances, jointly explains $16.3 \%$ of the total variation. Environmental variables, connected with the type of substratum (i.e. the coverage of raised bogs and the type of geological deposits) explain only $6 \%$ of variation. It is not possible to determine which environmental factors are responsible for the remaining $4.6 \%$ of variation in the studied data set (Fig. 20).

\subsubsection{Contemporary flora as an indicator of habitat changes}

In the analysis aimed at identification of the best preserved and the most disturbed fragments of the studied area, it was assumed that the changes in the qualitative and quantitative structure of flora may be treated as an indicator of habitat transformation due to anthropopressure. The analysis covered the spatial diversity of such features of contemporary flora as: enrichment in synanthropic species, terophytes or anthropophytes, and values of trophy, acidity, light, humidity and humus content indicators (Figs 21-28).

Spatial differentiation of number of synanthropic species, terophytes and anthropophytes in the studied area (Figs 21-23) indicate that these taxa are concentrated mainly around human settlements, especially in the region of Dębki and Karwia villages. In the remaining area these species were recorded in lower numbers, and almost complete lack of their localities within raised bogs and transitional mires was observed.

Mean values of trophy and acidity indicators in the research area reflect variation of studied habitats from oligo- to eutrophic $(1.7<\mathrm{TR}<4.8)$ and from strongly acidic to neutral/alkaline $(1.8<\mathrm{R}<4.6)$. Maps of spatial variation of mentioned indicators reflect the fact that oligotrophic and highly acidic character of substratum was preserved only in the central part of the Bielawskie Błoto raised bog, while the two remaining bogs as well as 
the margin of the Bielawskie Błoto have an increased trophy and acidity (Figs 24, 25). The most probable reason for these disturbances is agriculture use of the area (BuDYś 2005).

The light indicator in the studied area varies between 2.7 to 4.9 (moderate shade/halfshadow - full light) and is associated with the presence of forests and shrubs (Fig. 26). It should be emphasised that areas where the mean value of $\mathrm{L}$ indicator shows moderate shade or half-shadow $(\mathrm{L}<3.5)$, have a very low coverage in the studied area (ca 3\%), while the coverage of forests and shrubs is at present higher than $22 \%$. The reason is probably the fact that as little as $4 \%$ of the area covered by forest and shrub communities can be considered as relatively old forests (more than 100 years), and more than $60 \%$ are communities younger than 40 years. Author's own observation demonstrated that in the youngest forest and shrub phytocenoses the herbaceous layer did not undergo total transformation, and some remaining species of peatbog, heathland and meadow flora have influence on relatively high mean value of the light indicator.

The map of spatial diversity of the humus content indicator showed that soils rich in organic matter are at present concentrated within raised peatbogs, as well as in the valleys of Piaśnica, Białogórska Struga and Czarna Wda rivers (Fig. 27). On the map there is a distinctive area of high values of $\mathrm{H}$ indicator, located near the settlement of Szary Dwór, which is probably the remain of the Odargowskie Mire (see GrAEBNER 1895). Fragments of the area poor in humus $(\mathrm{H}<2)$ are located in the region of Łąki Dębkowskie Meadows, Karwieńskie Wetlands and in the neighbourhood of Ostrowska Moraine and Sławoszyńska Moraine. Drainage and agricultural use of mires caused decession of the thick layer of humus in the mineral-organic marginal part of researched area. Decrease of humus content in the centre of the studied area, e.g. in the region of Karwieńskie Błota village, is undoubtedly the effect of strong and long-term anthropic pressure. This area has the longest history of land use, and has been subjected to drainage works since 16th century.

The analysis of spatial distribution of mean values of the humidity index showed diversity of studied habitats from dry/fresh to wet ones $(2.5<\mathrm{W}<5.3)$ (Fig. 28). Habitats of the relatively highest moisture are located near Białogórski Channel, at Wierzchucińskie Bagno bog, in the eastern part of Bielawskie Błoto bog and in the Czarna Wda Valley. Parts of the area of low moisture values are located mainly in the region of Dębkowskie Meadows, Karwieńskie Wetlands and at the margin of Bielawskie Błoto raised bog.

\section{DISCUSSION}

\subsection{Symptoms of mire flora synanthropisation}

The results revealed that the main symptoms of flora transformation in disturbed mires are: the regression of species sensitive to the habitat disturbances as well as the invasion of environmentally and geographically alien species. These trends of change in flora are in agreement with the scheme of synanthropisation elaborated by FALIŃsKI (1966, 1972, 1998, 2000). The theory of synanthropisation assumes that this process consists mainly of hemerophobic species extinction, hemerophilous species expansion, apophytisation and neophytisation. 


\subsubsection{The regression of hemerophobic species}

Within Błota Przymorskie Plain at least 93 vascular plant species have become extinct during the last 198 years. Nearly half of them were characteristic of peatland complexes or inland waters. The retreat of mire species in habitats under anthropic pressure in Poland and in whole of Europe has been relatively well recognized (e.g. CzUBińsKi et al. 1954; JASNOWSKI et al. 1968; GöRS 1969; Herbichowa 1972, 1976; JASNOWSKI 1972; OlesińsKi \& OlkowsKi 1976; JaSNOWSKa \& JASNOWSKI 1977; JASNOWSKI \& ILNICKI 1988; DieRSSEN 1992; HeIKKILÄ 1992). This process has been documented not only by floristic observation but also by paleoecological data (JASNOwSKi et al. 1968; JASNOWSKI 1972, 1975; HEADLEY et al. 1992; TOBOLSKI 2003), which shows show that severe and rapid changes in mire flora took place during the last few centuries, during the time when human management has been developing (JASNOWSKI et al. 1968; JASNOWSKI 1972; HeAdLEY et al. 1992). To some extent, flora transformation can be also considered as a natural, long term process of succession in bogs and fens, but this aspect was studied only in particular types of mires - Baltic raised bogs (HeRBICHOwA 1998) and spring mires (WoŁEJKO 1991).

The analysis of regression of bog flora revealed that only some hollow species (representing Rhynchosporion albae in the Scheuchzerietalia palustris order) became extinct, while all those from hummocks (from the Oxycocco-Sphagnetea class) persisted within the studied area for the last 200 years (BuDYś 2004). The domination of hummock species in drained bogs in Denmark was pointed out by AABY (1994). In Poland this process needs to be studied as it can give some clues as to the possibilities of the persistence of mire species in bogs submitted to anthropic pressure.

\subsubsection{The expansion of hemerophilous species and neophytisation}

The number of species in the flora of Polish pristine mires is estimated at 130-230 (TOŁPA et al. 1967; JASNOWSKI 1972, 1975). Contemporary flora of studied peatlands is extremely rich and consists of 958 vascular plant species. The presence of alien species in disturbed mires was reported by JASNOWSKi et al. (1968), JASNOWSKI (1972), DiERSSEN (1992), AABY (1994), Celka \& Szkudlarz (2000), Zazuski \& Kamińska (2000) and Tomassen et al. (2004), among others, but there has been no systematic study regarding this problem. The results of past research suggest that the enrichment of mire flora is caused by desiccation, microclimatic changes, eutrophication or particular human activities such as transportation or mowing (Shaw \& Wheeler 1992; Aaby 1994; Celka \& SzKudlarz 2000; Tomassen et al. 2004). The present results reveal that the main forms of anthropic pressure which stimulate the increase in the number of species are: the development of drainage systems, transportation, hay-meadow farming, the use of land as pasture and waste disposal.

The most interesting aspect of mire flora enrichment is the expansion of geographically alien species. JASNOWSKI (1972) revealed that only five neophytes were inhabited in peatlands. Although there were 196 anthropophytes recorded in the present-day flora of the studied area, one third of them are diaphytes, which are not able to inhabit permanently in this type of habitat. Moreover, most of the alien species are classified as extremely rare or rare (frequency class I and II), except for some more common archaeophytes. On the other hand, archaeophytes are considerably less frequent in oligo- or mesohemerobic habitats 
than kenophytes. Such a conclusion was also reached by JACKOwIAK (1990), in regard to the flora of the city of Poznan. The relatively wide ecological amplitude of kenophytes is the reason for their expansiveness (РYšEK et al. 2003; TOKARSKA-GUZIK 2005), whereas archaeophytes are more often attached to a segetal habitat.

The mire flora transformation should be considered in terms of spatial bearing as well. The results show that raised bog and transition mire flora are much less enriched in synanthropic species (according to sociological classification) and anthropophytes than fen flora. Moreover, the alien species within raised bogs are recorded almost entirely in anthropogenic habitats such as hard-surfaced roads. The reasons for the resistance of bog habitats to alien species expansion are not well recognized. Firstly, one can assume that the anthropic pressure in these habitats is less intensive than in fens, or that there is a lack of some forms of activity which stimulate the flora enrichment (e.g. settlement). Secondly, environmental features such as high ground water level, scarcity of nutrients and high acidity can be limiting factors for alien species, even if the bog is significantly destroyed. Cleland et al. (2004) recorded a positive correlation between the probability of anthropophytes settlement and floristic diversity in plant communities. They also proved that alien species are rarely able to inhabit if the bank of available nutrients is used up by resident species. These facts suggest that extremely low fertility of raised bogs and transitional mires can be the main reason which hampers the invasion of hemerophilous species.

\subsection{The reasons for mire flora synanthropisation}

The regression of peat-forming species results, in most cases, from the desiccation of peat (GÖRS 1969; JASNOWSKI 1972; JASNOwsKi et al. 1968; HerBichowA 1979). In Błota Przymorskie Plain the drainage was very intensive - a possible cause of the retreat of wetland species; especially since a lot of mire species became extinct after 1940, when the bulk of the drainage measures were completed.

The lowering of the ground water table in the studied area caused shrinkage of the peat layer and, locally, even its complete decay. As a result, some islands of mineral soil within the complex of organic deposits were created. Such changes in Poland were observed by ILNICKI (1965); ROGUSKI \& BIEŃKIEWICZ (1967) and JASNOWSKI et al. (1968), among others. In Błota Przymorskie Plain the enlargement of the area of mineral or organo-mineral soils is the reason for the enrichment in mire flora in sandy grassland and heathland species and in annual species typical for synanthropic habitats.

The drainage results not only in peat humification, but stimulates secondary succession of trees and shrubs in peatlands as well (TALlis 1983; JASNOWSKI \& ILNICKI 1988). The development of trees is a threat for peat-forming species because of competitive interaction (e.g. limitation of light) and its contribution to reducing soil moisture (TовоLSкI 2003). The intensive succession of forest communities was observed in the studied area in the 1950s (in Wierzchucińskie Bagno bog) and 1970s (in Bielawskie Błoto and Łebcz raised bogs), which could be the reason for the extinction of several bog species noted for the last time between 1941 and 1979 (e.g. Scheuchzeria palustris, Lycopodiella inundata, Drosera intermedia).

Another form of anthropic pressure which significantly modifies the environment and flora of mires is peat exploitation (Podbielkowski 1960; Tallis 1983; Aaby 1994; Celka \& 
SZKUDLARZ 2000). The main result of mining, except the obvious limitation in peat surface available for plant growth, is the instability in the hydrological regime and the development of specific microrelief with damp peat digs and desiccated embankments (TALLIS 1983; AABY 1994). If the water level in post-exploitation digs is high enough, they can form a suitable habitat for the growth of bog flora (PODBIELKOwSKI 1960; JASNOwSKI et al. 1968; Görs 1969). The depth of mining, however, has an influence on species composition in regenerating communities (TALLIS 1983). The massive growth of rush species, observed in digs in the Kebcz raised bog, points out that the layer of eutrophic deposits underlying oligotrophic peat was exposed during exploitation. On the other hand, embankments of digs can play a role in the initiation of forest succession in mires. In pristine mires the settlement of trees takes place on dry hummocks, but is limited by seasonal fluctuations in the water table level (GODWIN \& BHARUCHA 1932; TALlis 1983). In post-exploited areas dried dikes are often overgrown by birch or pine trees. Such a process is observed for instance in the western part of the Bielawskie Błoto raised bog.

The greater part of the studied area, especially within the fen habitat, is nowadays turned into hay-meadows, pastures or arable fields, which significantly affects the floristic composition. Mowing and pasturing have a different influence on raised bog habitat and fen habitat. It was proven by HeathwaIte $e t$ al. (1993) that, from a phytocoenotical point of view, there is no difference between raised bogs submitted to hay-meadow farming and mineral habitats treated in the same way. The results of the present research are similar, although there were some remnants of the bog flora (e.g. individuals of Erica tetralix or Drosera rotundifolia) found within meadows established in the bog habitat. In the fen habitat mowing and pasturing leads to the domination of meadow species, especially grasses (Pearsall 1956), but such treatment also allows some fen species or sedge rush species to persist. Mowing is particularly needed in fen communities when the ground water table level is lowered, because it prevents tree and shrub establishment (WHEELER 1988; FoJT 1992a; SHAw \& WhEeLER 1992). Agricultural use of peatlands completely changes the flora, regardless of the ecological type of mire. JASNOWSKI et al. (1968) pointed out that in ploughed wetlands, where the peat layer has decayed, secondary vegetation has no features referring to the primary type of habitat. The present research is in agreement with their findings.

The next serious threat for the persistence of raised bog and poor fen flora is eutrophication. This phenomenon is particularly important in Western Europe, where ground waters are supplied with significant amounts of nitrogen and phosphorous compounds through rainfall (Press et al. 1986; AERTs et al. 1992; FoJt 1992b; TwEnHÖWEN 1992; AABY 1994; TOMASSEN et al. 2004). The spatial differentiation of trophic indicators in the studied area shows that eutrophic habitats are rather rare and scattered, and generally the trophic gradient between bogs and fens is still distinct. Points with enormously high mean values of trophic indicators were noted mainly within anthropogenic habitats, like farmyards and disposal sites. Moreover, in raised bog habitats such places are observed in the case of agricultural use (BUDYś 2005). Eutrophication can also be a problem in bog pools, which are resting and feeding places for migrating birds, e.g. in the Bielawskie Błoto raised bog. Such a case was mentioned by TOMASSEN et al. (2004), who studied the expansion of Molinia and Betula in an Irish peat bog where bird droppings caused enlarged nutrients supplies.

The most sweeping changes in mire flora, however, are caused by human settlement. The studied site is located in a coastal zone, so many villages have become tourist resorts 
and relatively big area of wetlands has been colonized, for instance near the villages of Karwieńskie Wetlands and Karwia. In these places, where the peatland habitat has been destroyed, mire flora has survived only in small patches, e.g. in drainage ditches. Moreover, settlement is the most important factor which stimulates the expansion of geographically alien species, especially kenophytes in disturbed mires.

\subsection{The direction and progress of synanthropic changes}

The analysis of successive stages in studied peatland flora synanthropisation revealed that the main trends of change are: the increase of floristic diversity; the substitution of mire species with species of wide sociological amplitude, synanthropic species, meadow species and forest species; the increasing role of terophytes and phanerophytes; and the increase of the proportion of anthropophytes. The obtained results confirm the theory of FALIŃSKI (1972), which says that anthropogenic changes in flora proceed towards eurytopisation, allochtonisation and complication. According to FALIŃsKi (1972), the decline of primary features of plant cover, which were prescribed by floristic and climatic history, is the consequence of synanthropisation. The flora of Błota Przymorskie Plain, despite far reaching qualitative and quantitative changes, is still connected, to some degree, with the primary type of habitat. Even though the bogs and fen habitats in the researched area were submitted to analogous forms of pressure, their flora is distinct, for instance with respect to mean values of ecological indicators. The differences in flora of these two types of mire are lost only in terms of such drastic forms of anthropopressure as waste disposal. Therefore, the hypothesis that the extent and symptoms of flora synanthropisation in peatlands depend both on the form of human pressure and ecological type of mire is proven.

From a geobotanical point of view, the studied area still has some features typical to Polish coastal mires (CzUBIŃsKi 1950). The coexistence of Atlantic and boreal species in contemporary flora can still be observed. However, as a result of anthropogenic changes in habitats (e.g. the development of dry heathlands or sandy grasslands), the proportion between these two groups of species has moved towards Atlantic range species (BuDYś 2006).

\section{THE MAIN FINDINGS AND CONCLUSIONS}

During the past 198 years in the flora of vascular plants of the Błota Przymorskie Plain and Płutnica Valley 958 taxa were listed. The contemporary flora of studied peatlands is extremely rich and consists of 808 vascular plant species. The main forms of anthropic pressure which stimulate the increase in the number of species are: the development of drainage systems, transportation, hay-meadow farming, the use of land as pasture and waste disposal.

Among 93 species, which became locally extinct, species associated with aquatic habitats and habitats of high groundwater level comprise $49 \%$. The greatest losses in flora were stated after 1940, when the bulk of the drainage measures were completed. 
The most important trends of changes in flora of disturbed mires, apart from extinction of hemerophobic species, are: the increase of floristic diversity; the substitution of mire species with species of wide sociological amplitude, synanthropic species, meadow species and forest species; the increasing role of terophytes and phanerophytes; and the increase of the proportion of anthropophytes.

Even though the bogs and fen habitats in the researched area were submitted to analogous forms of pressure, their flora is distinct, for instance with respect to acidity and trophy of substratum.

Among analysed environmental factors, which influenced the spatial differentiation of contemporary flora, the greater explanatory power have anthropogenic variables (the percentage of the land cover classes, the length of roads, the length of drainage channels and the age of disturbances) than variables connected with the geological character of the substratum (the coverage of raised bogs and the type of geological deposits).

The results of the presented research lead to the following conclusions: (1) anthropic pressure in coastal mires leads to ahemerobic habitat disappearance, oligohemerobic habitat fragmentation and the development of habitats with a higher degree of hemeroby - as an effect of this process a mosaic of secondary habitats develops and floristic diversity increases; (2) the advancement of synanthropisation processes depends both on the form and intensity of anthropic pressure and on the former ecological type of mire, while bog habitats are more resistant to alien species expansion than fens; (3) despite deep flora disturbances such as eurytopisation or allochtonisation, the contemporary flora of coastal peatlands still has some characteristic features connected with geology, ecological differentiation and geobotanical location; (4) flora synanthropisation process on disturbed mires still needs to be studied.

Acknowledgments. I would like to thank my supervisor, Professor Maria HeRBICHOWA, for her all-round help at
every stage of preparation of my doctoral dissertation. I am grateful to Professor Bogdan JACKOWIAK and Pro-
fessor Tomasz ZAŁUSKI, the reviewers of the dissertation, as well as anonymous reviewers of this paper for their
helpful comments. I am also very grateful to Professor Jacek URBAŃSKI for the time he devoted to me during
numerous consultations concerning GIS techniques and DSc. Agnieszka PIERNIK for discussion about multivari-
ate analyses. The following taxonomists helped me with verification of difficult taxa: DSc. W. BARTOSZEK - genus
Alchemilla, DSc. A. CZARNA - species Agrostis vinealis, DSc. J. MiNASIEWICZ - genus Dactylorhiza, DSc. E. ProsZ-
KIEWICZ - genus Euphrasia, Professor K. RosTAŃSKI - genus Oenothera, Professor D. SzLACHETKO - genus Epi-
pactis and Corallorhiza, Professor J. SZMEJA - genus Callitriche, DSc. J. ZALEWSKA-GAEOSZ - genus Potamogeton;
Professor J. ZIELIŃSKI - genus Rubus, Aronia, Salix and Populus. This research was financed by the State Committee for Scientific Research (KBN 6PO4F 044019, KBN 3PO4F 026 22, KBN 2PO4G 015026).

\section{REFERENCES}

AABY, B. 1994. Monitoring Danish raised bogs. In: A. GrüNIG (ed.), Mires and Man. Mire conservation in a densely populated country - the Swiss Experience. Swiss Federal Instute for Forest, Snow and Landscape Research, Birmensdorf, 284-300.

Aerts, R., Wallen, B. \& Malmer, N. 1992. Growth-limiting nutrients in Sphagnum-dominated bogs subject to low and high atmospheric nitrogen supply. J. Ecology 80: 131-140.

Augustowski, B. 1969. Środowisko geograficzne województwa gdańskiego w zarysie. WSP, Gdańsk, 107 pp. 
Augustowski, B. 1974. Rzeźba terenu. In: J. Moniak (ed.), Studium geograficzno-przyrodnicze i ekonomiczne województwa gdańskiego. GTN, Gdańsk, 37-90.

Biernat, A., Jakubowska, B., Medowski, T. \& Nogaczewski, M. 2000. Charakterystyka środowiska kulturowego. In: E. Gerstmannowa (ed.), Materiały do monografii przyrodniczej regionu gdańskiego. T. 3. Nadmorski Park Krajobrazowy. Wojewódzka Komisja Ochrony Przyrody w Gdańsku. Wojewódzki Konserwator Przyrody w Gdańsku. Wyd. Marpress, Gdańsk, 80-91.

Budyś, A. 2001. Aktualny stan populacji Rhynchospora fusca (L.) W.T. Aiton, na Bielawskim Błocie (Pobrzeże Kaszubskie). Acta Botanica Cassubica 2: 77-81.

BudYś, A. 2004. Persistence and changes in raised bogs' vascular flora in a coastal zone exemplified by the Bielawskie Błoto bog (Kaszuby Coastal Region). In: L. WołeJKo, J. JASNOwsKa (eds.), The future of Polish mires. Monogr. AR w Szczecinie, 171-176.

BuDYś, A. 2005. Antropogeniczne przemiany flory roślin naczyniowych torfowisk w strefie przymorskiej na przykładzie wschodniej części Pobrzeża Kaszubskiego. Katedra Taksonomii Roślin i Ochrony Przyrody Uniw. Gdańskiego, Gdańsk. Doctoral thesis. Typescript.

BuDYś, A. 2006. Phytogeographic aspects of transformation of the vascular plant flora in coastal mires exemplified by the eastern part of the Kashubian Coastal Region (northern Poland). Biodiversity Resesearch and Conservation 1-2: 89-91.

Celka, Z., Szkudlarz, P. 2000. Anthropogenic transformations of the Bagno Chlebowo peat-bog (Wielkopolska Province). In: B. JACKOWIAK, W. ŻUKOWSKI (eds.), Mechanism of anthropogenic changes of the plant cover. Publications of the Department of Plant Taxonomy of the Adam Mickiewicz University. Bogucki Wyd. Naukowe, Poznań, 193-200.

Chmiel, J. 1993. Flora roślin naczyniowych wschodniej części Pojezierza Gnieźnieńskiego i jej antropogeniczne przeobrażenia w wieku XIX i XX. Prace Zakładu Taksonomii Roślin Uniw. Adama Mickiewicza w Poznaniu 1. Sorus, Poznań 1: 1-202.

Cleland, E.E, Smith, M.D., Andelman, S.J., Bowles, C., Carney, K.M., Horner-Devine, M.C., Drake, J.M., Emery, S.M., Gramling, J.M. \& VAnDERmast, D.B. 2004. Invasion in space and time: non-native species richness and relative abundance respond to inerannual variation in productivity and diversity. Ecology Letters 7: 947-957.

Cross, J.R. 1992. Man's impact on the peatlands of Ireland and its implications for conservation. In: O.M. BRAGG, P.D. Hulme, H.A.P. Ingram \& R.A. Robertson (eds.), Peatland Ecosystems and Man: An Impact Assessment. Dep. of Biol. Sci., University of Dundee \& IPS, Dundee-Jyväskylä, 345-350.

CzubIŃski, Z. 1950. Zagadnienia geobotaniczne Pomorza. Badania Fizjogr. Pol. Zach. 2, 4: 439-658.

Czubiński, Z., Borówko, Z., Filipiszynowa, M., Krawiecowa, A., OŁtuszewski, W., Szweykowski, J. \& TobolewSKI, Z. 1954. Bielawskie Błoto - ginące torfowisko atlantyckie Pomorza. Ochrona Przyrody 22: 67-159.

Dierssen, K. 1982. Die wichtigsten Pflanzengesellschaften der Moore NW-Europas. Conservatorie et Jardin botaniques, Geneve, $382 \mathrm{pp}$.

Dierssen, K. 1992. Peatland vegetation and the impact of Man. In: O.M. BragG, P.D. Hulme, H.A.P. Ingram \& R.A. Robertson (eds.), Peatland Ecosystems and Man: An Impact Assessment. Dep. of Biol. Sci., University of Dundee \& IPS, Dundee-Jyväskylä, 67-93.

Council Directive 92/43/EEC of 21 May 1992 on the conservation of natural habitats and of wild fauna and flora.

EsRI 2001-2002. Using ArcGIS Spatial Analyst. ESRI Inc., New York, 300 pp.

FALIŃSKI, J.B. 1966. Próba określenia zniekształceń fitocenozy. System faz degeneracyjnych zbiorowisk roślinnych. Ekologia Polska, Ser. B 12, 1: 31-42.

FALIŃSKI, J.B. 1972. Synantropizacja szaty roślinnej - próba określenia istoty procesu i głównych kierunków badań. Phytocoenosis 1, 3: 157-170.

FALIŃSKI, J.B. 1998. Invasive alien plants, vegetation dynamics and neophytism. In: J.B. FALIŃSKI, W. ADAmowsKI \& B. JACKOWIAK (eds.), Synanthropization of plant cover in new Polish research. Phytocoenosis 10 (N.S.), Suppl. Cart. Geobot. 9: 163-187.

FALIŃSKI, J.B. 2000. Invasive alien plants and vegetation dynamics. In: U. Storfinger, K. EdwARDS, I. Kowarik \& M. Williamson (eds.), Plant Invasions. Buvkhuys Publ., Leiden, 3-21.

FoJT, W. 1992a. The management of fens. In: O.M. BragG, P.D. Hulme, H.A.P. Ingram \& R.A. Robertson (eds.), Peatland Ecosystems and Man: An Impact Assessment. Dep. of Biol. Sci., University of Dundee \& IPS, Dundee-Jyväskylä, 399-401. 
FoJT, W. 1992b. British fens and their conservation problems. In: O.M. BragG, P.D. Hulme, H.A.P. Ingram \& R.A. Robertson (eds.), Peatland Ecosystems and Man: An Impact Assessment. Dep. of Biol. Sci., University of Dundee \& IPS, Dundee-Jyväskylä, 357-362.

Gerstmannowa, E. 1978-1981. Studium kształtowania środowiska Nadmorskiego Parku Krajobrazowego. IKŚ, Gdynia. Typescript.

Godwin, H., Bharucha, F.R. 1932. Studies in the ecology of Wicken Fen. II. The fen water table and its control of plant communities. J. Ecol. 20: 157-191.

Gőrs, S. 1969. Der Wandel der Vegetation im Naturchutzgebiet Schwenninger Moos unter dem Einfluss des Menschen in zwei Jahrhunderten. Die Nat. u. Landschaftschutzgebiete Bad.-Württ. 5: 190-284.

Graebner, P. 1895. Zur flora der Kreise Putzig, Neustadt Wspr. und Lauenburg im Pomm. Ber. d. Westpr. Bot.Zool. Vereins 18: 271-396.

Headley, A.D., Wheeler, B.D. \&, Baker, A.J.M. 1992. The impact of man on the vegetation of Crymlyn Bog. In: O.M. BragG, P.D. Hulme, H.A.P. Ingram \& R.A. Robertson (eds.), Peatland Ecosystems and Man: An Impact Assessment. Dep. of Biol. Sci., University of Dundee \& IPS, Dundee-Jyväskylä, 257-261.

Heathwaite, A.L., Eggelsmann, R. \& Gőttlich, Kh. 1993. Ecohydrology, mire drainage and mire conservation. In: Kн. Gőtrtich (ed.), Mires, Pocess, Exploitation and Conservation. Wiley, Chichester, 417-484.

Heikkilä, R. 1992. Changes in distribution of some plant species of the euthropic fens of southern Finland. In: O.M. Bragg, P.D. Hulme, H.A.P. Ingram \& R.A. Robertson (eds.), Peatland Ecosystems and Man: An Impact Assessment. Dep. of Biol. Sci., University of Dundee \& IPS, Dundee-Jyväskylä, 244-249.

Herbich, J., Herbichowa, M. 2002. Szata roślinna torfowisk. In: P. Ilnicki (ed.), Torfowiska i torf. Wyd. AR w Poznaniu, Poznań, 179-203.

Herbichowa, M. 1972. Co pozostało z atlantyckiego torfowiska Bielawskie Błoto? Chrońmy Przyr. Ojcz. 28, 4: 30-38.

Herbichowa, M. 1976. Zanikanie gatunków na przykładzie atlantyckich torfowisk Pobrzeża Kaszubskiego. Phytocoenosis 5, 3/4: 247-254.

Herbichowa, M. 1979. Roślinność atlantyckich torfowisk Pobrzeża Kaszubskiego. GTN Acta Biol. 5: 1-51.

Herbichowa, M. 1998. Ekologiczne studium rozwoju torfowisk wysokich właściwych na przykładzie wybranych obiektów z środkowej części Pobrzeża Bałtyckiego. Wyd. Uniw. Gdańskiego, Gdańsk, 119 pp.

Herbichowa, M., Herbich, J. \& Budyś, A. 2001. Dokumentacja przyrodnicza projektowanego rezerwatu przyrody “Długosz królewski w Wierzchucinie”. Dla Wojewódzkiego Konserwatora Przyrody, Gdańsk. Typescript.

ILNICKI, P. 1965. Osiadanie torfowisk. Wiad. Melior. Łąk. 37: 57-61.

INGRAM, H.A.P. 1992. Introduction to the ecohydrology of mires in the context of cultural perturbation. In: O.M. Bragg, P.D. Hulme, H.A.P. Ingram \& R.A. Robertson (eds.), Peatland Ecosystems and Man: An Impact Assessment. Dep. of Biol. Sci., University of Dundee \& IPS, Dundee-Jyväskylä, 67-93.

JACKOWIAK, B. 1990. Antropogeniczne przemiany flory roślin naczyniowych Poznania. Wyd. Nauk. Uniw. Adama Mickiewicza, Poznań, 232 pp.

JACKOWIAK, B. 1998. Struktura przestrzenna flory dużego miasta. Studium metodyczno-problemowe. Prace Zakładu Taksonomii Roślin Uniw. Adama Mickiewicza w Poznaniu. 8. Bogucki Wyd. Naukowe, Poznań, 228 pp.

JALAS, J. 1955. Hemerobe und hemerochore Pflanzenarten. Ein terminologischer Reformversuch. Acta Soc. Fauna Flora Fenn. 72, 11: 1-15.

JASNOWSKA, J., JASNOWSKI, M. 1977. Zagrożone gatunki flory torfowisk. Chrońmy Przyr. Ojcz. 33, 4: 5-14.

JASNOwSKI, M. 1972. Rozmiary i kierunki przekształceń szaty roślinnej torfowisk. Phytocoenosis 1, 3: $193-209$.

JASNOwski, M. 1975. Torfowiska i tereny bagienne w Polsce. In: N.J. KAC (ed.), Bagna kuli ziemskiej. PWN, Warszawa, 356-390.

JASNOwsKi, M., ILNICKI, P. 1988. Przykłady przeobrażeń gleby i roślinności pod wpływem zmian stosunków wodnych. In: R. OlaczeK (ed.), Zasoby glebowe i roślinne. PWRiL, Warszawa, 427-469.

JASNOWSKI, M., JASNOWSKA, J. \& MARKOWSKI, S. 1968. Ginące torfowiska wysokie i przejściowe w pasie nadbałtyckim Polski. Ochrona Przyrody 33: 69-124.

Jongman, R.H.G., Ter BraAk, C.J.F. \& Tongren van, D.F.R. 1987. Data analysis in community and landscape ecology. Pudoc, Wageningen, 299 pp.

Kondracki, J. 2001. Geografia regionalna Polski. PWN, Warszawa, 441 pp.

Kornaś, J. 1968. Prowizoryczna lista nowszych przybyszów synantropijnych (kenofitów) zadomowionych w Polsce. In: J.B. FALińsKi (ed.), Synantropizacja szaty roślinnej. I. Neofityzm i apofityzm w szacie roślinnej Polski. Mater. Zakł. Fitosoc. Stos. Uniw. Warszawskiego 25: 43-53. 
KornAś, J. 1972. Wpływ człowieka i jego gospodarki na szatę roślinną Polski - flora synantropijna. In: W. SzAFER \& K. ZARZYCKI (eds.), Szata roślinna Polski, T. 1. PWN, Warszawa, 95-127.

Kornaś, J. 1981. Oddziaływanie człowieka na florę: mechanizmy i konsekwencje. Wiad. Bot. 25, 3: 165-182.

KowariK, I. 1988. Zum menschlichen Einfluss auf Flora und Vegetation. Teoretische Konzepte und ein Quantifizierungsansatz am Beispiel von Berlin (West.). Landschaftsentwicklung und Umweltforchung TU Berlin 56: $1-280$.

Kwiecień, K., Taranowska, S. 1974. Warunki klimatyczne. In: J. Moniak (ed.), Studium geograficzno-przyrodnicze i ekonomiczne województwa gdańskiego. GTN, Gdańsk, 91-143.

LePš, J., Šmilauer, P. 2004. Multivariate Analysis of Ecological Data. Course materials. Fac. of Biol. Sci. Univ. of South Bohemia, České Budějovice. Typescript.

LiPKA, K. 1984. Ocena gospodarcza złóż torfowych w Polsce. In: S. KozŁowsKi (ed.), Gospodarka zasobami przyrody. PAN. Kom. Przestrz. Zagospod. Kraju 85: 56-77.

Machnikowski, M., Angiel, M., BŁaszkowska, B., Knapik, A., Gromadzki, M. \& Przystupa, B. 1985. Opracowanie przyrodnicze i koncepcja ochrony Bielawskich Błot. Instytut Kształtowania Środowiska Oddział w Gdańsku. Typescript.

Matuszkiewicz, W. 2001. Przewodnik do oznaczania zbiorowisk roślinnych Polski. In: J.B. FaLiński (ed.), Vademecum Geobotanicum. PWN, Warszawa 3: 15-537.

Minasiewicz, J., Tukalzo, P. \& Trzepanowska, K. 2004. Dactylorhiza incarnata (L.) Soó w regionie gdańskim zmienność morfologiczna i genetyczna populacji oraz stan zachowania stanowisk. Acta Botanica Cassubica 4: 139-160.

MireK, Z. 1981. Problemy klasyfikacji roślin synantropijnych. Wiad. Bot. 25, 1: 45-54.

Mirek, Z., Pięroś-Mirkowa, H., Zając, A. \& Zając, M. 2002. Flowering plants and pteridophytes of Poland. A checklist. In: Z. Mirek (ed.), Biodiversity of Poland 1. W. Szafer Institute of Botany, Polish Academy of Sciences, Kraków, 442 pp.

NARwojsz, A. 2000. Hydrografia parku i jego otoczenia. In: E. Gerstmannowa (ed.), Materiały do monografii przyrodniczej regionu gdańskiego. T. 3. Nadmorski Park Krajobrazowy. Wojewódzka Komisja Ochrony Przyrody w Gdańsku. Wojewódzki Konserwator Przyrody w Gdańsku. Wyd. Marpress, Gdańsk, 18-22.

OKruszko, H. 1993. Transformation of fen peat soil under the impact of draining. Zesz. Probl. Post. Nauk Roln. 406: 3-73.

OLACZEK, R. 1982. Synanthropization of phytocenoses. Memor. Zool. 37: 93-112.

Olesiński, L., OlKowsKI, M. 1976. Zanikanie niektórych gatunków torfowiskowych roślin naczyniowych w północno-wschodniej Polsce. Phytocoenosis 5, 3/4: 255-264.

PawŁowsKa, S. 1977. Charakterystyka statystyczna I elementy flory polskiej. In: W. SzAFER, K. ZARZYCKI (eds.), Szata roślinna Polski. T. 1. PWN, Warszawa, 237-269.

Pearsall, W.H. 1956. Two blanket bogs in Sutherland. J. Ecol. 44: 493-516.

PIERNIK, A. 2005. Zastosowanie metod numerycznych w ekologii roślin. Materiały do kursu. Uniw. Mikołaja Kopernika, Toruń. Typescript.

Piotrowska, H., ŻuKowski, W. \& JACKOwiaK, B. 1997. Rośliny naczyniowe Słowińskiego Parku Narodowego. Prace Zakładu Taksonomii Roślin Uniw. Adama Mickiewicza w Poznaniu. Bogucki Wyd. Naukowe, Poznań 6: 1-216.

PodBieLKowsKi, Z. 1960. Zarastanie dołów potorfowych. Monogr. Bot. 10, 1: 1-144.

Polakowski, B. 1976. Zanikanie składników torfowiskowych na Pojezierzu Mazurskim. Phytocoenosis 5, 3/4: 265-274.

Press, M.C., Woodin, S.J. \& LeE, J.A. 1986. The potential importance of an increased atmospheric nitrogen supply to the growth of ombrotrophic Sphagnum species. New Phytologist 103: 45-55.

PYŠEK, P., JAROŠIK, V. \& KUČERA, T. 2003. Inclusion of native and alien species in temperate nature reserves: an historical study from Central Europe. Conservation Biology 17, 5: 1414-1424.

RAUNKIAER, C. 1905. Types biologiques pour la géographie botanique. Overs. Kongel. Dske Vidensk. Selsk. Forh. Medlemmers Arbeider 1905 5, 347-437.

RogusKi, W., BIEŃKIEwICZ, P. 1967. Zanikanie gleb organogenicznych w wyniku melioracji. Zesz. Probl. Post. Nauk Roln. 72: 61-86.

Shaw, S.C., Wheeler, B.D. 1992. Agricultural land use and rich fen vegetation. In: O.M. BragG, P.D. Hulme, H.A.P. Ingram \& R.A. Robertson (eds.), Peatland Ecosystems and Man: An Impact Assessment. Dep. of Biol. Sci., University of Dundee \& IPS, Dundee-Jyväskylä, 238-243.

Sudnik-Wóscikowska, B. 1998. Czasowe i przestrzenne aspekty procesu synantropizacji flory na przykładzie wybranych miast Europy Środkowej. Wyd. Uniw. Warszawskiego, Warszawa, 167 pp. 
Sukopp, H. 1972. Wandel von Flora und Vegetation in Mitteleuropa under dem Einfluss des Menschen. Ber. ü. Landwirtschaft. Hrsg. Bundesministerium f. Ernähg, Landwirschaft u. Forsten 50, 1: 112-139.

Sukopp, H. 1976. Dynamik und Konstanz in der Flora der Bundesrepublik Deutschland. Ssch. R. Vegetationskunde 10: 9-27.

Szafranówna, H. 1926. Łąki nad ujściem Piaśnicy. Ochrona Przyrody 6: 85-86.

Tallis, J.H. 1983. Changes in wetland communities. In: A.J.P. Gore (ed.), Mires: swamp, bog, fen and moor. General studies (Ecosystemes of the World 4A). Elsevier Sci. Publ. Comp. Amsterdam-Oxford-New York, 311-347.

Ter Braak, C.J.F., Prentice, I.C. 1988. A theory of gradient analysis. Advances in Ecological Research 18: 271313.

Ter BraAk, C.J.F., Šmilauer, P. 2002. CANOCO Reference manual and CanoDraw for Windows User's guide: Software for Canonical Community Ordination (version 4.5). Microcomputer Power. Ithaca. New York, 500 pp.

Tовоцsкi, K. 2003. Torfowiska na przykładzie Ziemi Świeckiej. Tow. Przyjaciół Dolnej Wisły, Świecie, 256 pp.

Tokarska-Guzik, B. 2005. The Establishment and Spread of Alien Plant Species (Kenophytes) in the Flora of Poland. Wyd. Uniw. Śląskiego, Katowice, 192 pp.

ToŁPA, S., JASNOwski, M. \& PAŁCZYŃski, A. 1967. System genetyczny klasyfikacji torfów występujących w złożach Europy Środkowej. Zesz. Probl. Post. Nauk Roln. 76: 9-100.

Tomassen, H.B.M., Smolders, A.J.P., LimPens, J., LAmers, L.P.M. \& Roelofs, J.G.M. 2004. Expansion of invasive species on ombrotrophic bogs: desiccation or high N deposition? J. Appl. Ecol. 41: 139-150.

TwENHÖWEN, F.L. 1992. Effects of nitrogen deposition on the vegetation of a raised bog. In: In: O.M. BRAGG, P.D. Hulme, H.A.P. Ingram \& R.A. Robertson (eds.), Peatland Ecosystems and Man: An Impact Assessment. Dep. of Biol. Sci., University of Dundee \& IPS, Dundee-Jyväskylä, 231-237.

URBAŃSKI, J. 2001. Modelowanie kartograficzne strefy brzegowej morza. Wyd. Uniw. Gdańskiego, Gdańsk, 159 pp.

WHEELER, B.D. 1988. Species richness, species rarity and conservation evaluation of rich-fen vegetation in lowland England and Wales. J. Appl. Ecol. 25: 331-353.

Witek, T., Byczkowski, B. \& Chalecki, J. 1974. Charakterystyka i rozmieszczenie gleb. In: J. Moniak (ed.), Studium geograficzno-przyrodnicze i ekonomiczne województwa gdańskiego. GTN, Gdańsk, 193-210.

WoŁEJKo, L. 1991. Porównanie kompleksów źródliskowych rozwijających się w warunkach naturalnych i zmienionych w wyniku antropopresji. II. Flora i szata roślinna. Zesz. Nauk. AR w Szczecinie 149, Roln. 51: 69-90.

ZAJẠC, A. 1978. Założenia metodyczne "Atlasu rozmieszczenia roślin naczyniowych w Polsce". Wiad. Bot. 22, 3: 145-155.

ZAJĄC, A., ZaJĄC, M. (eds.). 1996-1998. Base and Distributional Atlas of vascular plants protected in Poland. Part I. Laboratory of Comp. Chorology, Institute of Botany, Jagiellonian Univ. www3.uj.edu.p1/IB/CHRONPOL/ geo/geo.html, date of exploration: 12.05.2002.

Zając, A., Zając, M. \& ToKarska-GuziK, B. 1998. Kenophytes in the flora of Poland: list, status and origin. Phytocoenosis 10 (N.S.), Suppl. Cartogr. Geobot. 9: 107-116.

ZaJĄC, E.U., ZaJĄC, A. 1975. Lista archeofitów występujących w Polsce. Zesz. Nauk. Uniw. Jagiellońskiego, Prace Botaniczne 3: 7-16.

ZaŁUski, T., KAMiŃSKA, A.M. 2000. Plant cover diversity of selected peatlands in the Urszulewo Plain in the aspect of synanthropisation. In: B. JACKOWIAK, W. ŻUKOwSKI (eds.), Mechanism of anthropogenic changes of the plant cover. Publications of the Department of Plant Taxonomy of the Adam Mickiewicz University. Bogucki Wyd. Naukowe, Poznań, 291-298.

Zarzycki, K., Trzcińska-Tacik, H., Różański, W., SzeląG, Z., Wolek, J. \& Korzeniak, U. 2002. Ecological indicator values of vascular plants of Poland. In: Z. Mirek (ed.), Biodiversity of Poland 2. W. Szafer Instytute of Botany, Polish Academy of Sciences, Kraków, 183 pp.

Cartographic materials

Aerial photographs 1947, 1958, 1964, 1976, 1984. Black-and-white. Panchromatic. Scale 1:10000 - 1:27 000. Centre of Ordnance Survey and Remote Sensing.

Aerial photographs 1996-1997. Colour. Panchromatic. Scale 1:10000. Main Centre of Geodetic and Cartographic Documentation.

Detailed geological map of Poland. 1978. Sheet Sławoszyno. Scale 1:50000. Ostaficzuk S., Jakubowicz B., Skompski S. Geological Publ.

Detailed geological map of Poland. 1985. Sheet Choczewo. Scale 1:50000. Skompski S. Geological Publ. 
Detailed geological map of Poland. 2002. Sheet Puck. Scale 1:50000. Skompski S. Ministry of Environment, PIG.

Geological documentation of mire near Wierzchucino. 1963. Scale 1:25000. The Institute for Land Reclamation and Grassland Farming. The Field Research Division in Elbląg. Mscr.

Geological documentation of peat bog in Sławoszyno-Władysławowo-Mechowo region. 1968. Scale 1:25000. Polish Society of Soil Science, Gdańsk Division. Mscr.

Geological documentation of peat deposits in Starzyński Dwór. 1957. Scale 1:25000. "GEOTORF” Peat Prospecting and Research Enterprise. Mscr.

Soil-agricultural map. 1973. Sheet Białogóra, Karwia, Karwieńskie Błoto, Łebcz, Mieroszyno, Odargowo, Ostrowo, Parszkowo, Sławoszyno, Starzyński Dwór, Sulicice, Tupadły, Werblinia, Wierzchucino, Żarnowiec. Scale 1: 5000. Provincial Office of Geodesy and Agricultural Infrastructure in Gdańsk.

Topographic map. (no printing date). Sheet Dembek. Scale 1: 25000. Berichtigt: Hauptoerm. Abt. V. 1939 (Troeder). Letzte Nachträge: Militär. Geogr. Institut, Warszawa 1934.

Topographic map. 1810. Karte von Ost - Preußen nebst Preußisch Lithauen und West Preußen nebst dem Netzdistrict, aufgenomen unter Leitung des Königlisch Preußischen Staats-Ministers Freiherrn [...] der Jahren von 1796 bis 1806. Scale 1:50000. Schrötter F. L. Historisch-geographischer Atlas des Preußenlandes. Section IV.

Topographic map. 1889. Kreis Putzig im Regierungs-Bezirke Danzig. Scale 1: 100000. Aufgenommen v. Kőnigl. Pr. Generalstaß 1862-1875.

Topographic map. 1911. Sheet Mechau. Scale 1: 25000. Kőnigl. Preuß. Landesaufnahme 1875. Herausegeben 1877.

Topographic map. 1918. Sheet Ostrau. Scale 1: 25000. Kőnigl. Preuß. Landesaufnahme 1875. Herausegeben 1877.

Topographic map. 1935. Sheet Żarnowiec. Scale 1:100000. Surveyed in 1928. WIG.

Topographic map. 1940. Sheet Mechau. Scale 1: 25000. Letzte Nachträge: Militär. Geogr. Institut, Warszawa 1934.

Topographic map. 1940. Sheet Ostrau. Scale 1: 25000. Letzte Nachträge: Militär. Geogr. Institut, Warszawa 1934.

Topographic map. 1940. Sheet Putzig. Scale 1: 25000. Letzte Nachträge: Militär. Geogr. Institut, Warszawa 1937.

Topographic map. 1941. Sheet Wittenberg. Scale 1: 25000. Berichtigt: Hauptoerm. Abt. V. 1939 (Troeder).

Topographic map. 1942. Sheet Zarnowitz. Scale 1: 25000. Berichtigt: Reichsamt f. L. A. 1939. Letzte Nachträge: Militär. Geogr. Institut, Warszawa 1937.

Topographic map. 2000-2002. Vector. Digital Cartographic Materials. Provincial Centre of Geodesy and Cartography in Gdańsk.

\section{SYNANTROPIZACJA FLORY ROŚLIN NACZYNIOWYCH TORFOWISK W STREFIE PRZYMORSKIEJ (POBRZEŻE KASZUBSKIE, POLSKA PÓŁNOCNA) - ZAKRES, PRZYCZYNY I UWARUNKOWANIA PRZESTRZENNE (streszczenie)}

Cel i teren badań. Celem pracy jest rozpoznanie zakresu antropogenicznych przemian flory na zróżnicowanych ekologicznie siedliskach torfowych strefy przymorskiej oraz zbadanie przestrzennych uwarunkowań i przyczyn tego procesu. Celem szczegółowym pracy jest: (1) ustalenie składu gatunkowego historycznej i współczesnej flory roślin naczyniowych na torfowiskach reprezentatywnych dla obszaru przymorskiego; (2) określenie przejawów, etapów i specyfiki transformacji flory na zaburzonych siedliskach torfowych; (3) rozpoznanie tendencji dynamicznych wybranych składników flory; (4) prześledzenie głównych etapów antropogenicznych zmian środowiska przyjętego terenu badań; (5) ustalenie zależności między jakościowym, ilościowym i przestrzennym zróżnicowaniem flory a formami 
antropogenicznych oddziaływań i stopniem przeobrażenia środowiska przyrodniczego oraz wskazanie najważniejszych czynników kształtujących strukturę flory współczesnej zmienionych siedlisk torfowych.

Do badań wytypowano wycinek pasa zatorfionych obniżeń, który rozciąga się między mierzejami a wysoczyznami morenowymi wzdłuż całego wybrzeża Bałtyku (KoNDRACKI 2001). Teren ten obejmuje kompleks dominujących przestrzennie torfowisk niskich oraz trzech torfowisk wysokich typu bałtyckiego (Fig. 1). Pod względem uwarunkowań geomorfologicznych, cech klimatycznych oraz typologicznego zróżnicowania torfowisk wybrany fragment Pobrzeża Kaszubskiego jest reprezentatywny co najmniej dla wschodniego odcinka wybrzeża Bałtyku. Ze względu na długotrwałą, bezpośrednią lub pośrednią antropopresję, teren ten współcześnie stanowi swoistą mozaikę siedlisk zróżnicowanych pod względem stopnia przekształcenia i sposobu użytkowania. Spośród innych podobnych kompleksów obszar ten wyróżnia się stosunkowo bogatą, choć niepełną dokumentacją florystyczną pochodzącą z wieków XIX i XX. Według przyjętej w niniejszym opracowaniu regionalizacji Augustowskiego $(1969,1974)$ badany teren jest położony w obrębie Pobrzeża Kaszubskiego i obejmuje Równinę Błot Przymorskich oraz fragment Pradoliny Płutnicy (Fig. 2).

Materiał i metody. Współczesny skład flory naczyniowej został ustalony na podstawie własnych badań terenowych prowadzonych w sezonach wegetacyjnych 2000-2004, uzupełnionych o dane z lat 1997-2002 pochodzące $\mathrm{z}$ opracowań innych autorów. Badany obszar został podzielony na 122 pola podstawowe (stanowiska) - kwadraty o powierzchni $1 \mathrm{~km}^{2}$, które zostały wydzielone w obrębie sieci ATPOL. W każdym kwadracie badań wykonano zdjęcia florystyczne w taki sposób, aby reprezentowały wszystkie możliwe typy użytkowania terenu oraz różne typy fitocenoz. Aktualna lista roślin naczyniowych uzupełniona została o wszystkie dane florystyczne pochodzące z wcześniejszych badań. W historii badań florystycznych umownie wydzielono pięć okresów obejmujących następujące lata: I - 18091896, II - 1897-1940, III - 1941-1979, IV - 1980-1996, V - 1997-2004. Baza danych liczy łącznie 81019 dat florystycznych, z czego do flory współczesnej odnosi się 74425 dat; na kartotekę historyczną składają się 6594 daty. Gatunki w bazie zostały scharakteryzowane pod względem frekwencji, przynależności fitosocjologicznej, przynależności do grup geograficzno-historycznych oraz form życiowych. Dynamikę poszczególnych taksonów we florze współczesnej określono na podstawie wskaźnika apofityzmu $\left(\mathrm{I}_{\mathrm{ap}}\right)$ oraz wskaźnika naturalizacji $\left(\mathrm{I}_{\text {nat }}\right)$. Badane siedliska sklasyfikowano pod względem stopnia hemerobii oraz ze względu na genezę i sposób użytkowania.

Analizę obecnego stanu oraz rekonstrukcję przemian wybranych elementów środowiska przyrodniczego przeprowadzono wykorzystując mapy topograficzne, mapy utworów powierzchniowych, szkice sytuacyjne z dokumentacji geologicznych złóż torfu oraz archiwalne i aktualne zdjęcia lotnicze. Na podstawie tych materiałów stworzono m.in. mapy klas pokrycia terenu w czterech przedziałach czasowych, mapy historycznej sieci dróg i cieków oraz syntetyczną mapę wieku zaburzeń. Na podstawie wybranych cech flory w punktach spisów florystycznych opracowano mapy wskaźnikowe obrazujące zaburzenia flory i siedliska, np. mapę liczby antropofitów, mapy średnich wartości wskaźników Zarzyckiego dla trofizmu, wilgotności i zawartości materii organicznej w glebie.

Zależności między zróżnicowaniem flory a wybranymi cechami środowiska zostały zbadane z wykorzystaniem analiz wielowymiarowych (DCA, PCA, RDA, CA) i technik GIS. 


\section{Wyniki}

Zakres przemian flory i cechy flory współczesnej. W ciągu ostatnich 198 lat we florze naczyniowej Równiny Błot Przymorskich i Pradoliny Płutnicy stwierdzono łącznie 958 taksonów, natomiast aktualną florę badanego terenu tworzy 808 taksonów. Flora obszaru siedliskowego torfowisk wysokich i przejściowych liczy 570 taksonów, a flora byłych torfowisk niskich - 927, z czego we florze współczesnej odnotowano odpowiednio 459 i 792 taksony roślin naczyniowych.

Spośród 150 gatunków, których współcześnie nie odnaleziono na badanym obszarze 93 można uznać za wymarłe (nie notowane co najmniej od roku 1979). Pozostałe 57 gatunków nieodnalezionych ma status niepewny (gatunki pospolite prawdopodobnie przeoczone $\mathrm{w}$ tracie obecnych badań, gatunki prawdopodobnie błędnie podane w trakcie poprzednich badań oraz gatunki, które nie były trwale zadomowione we florze). Wśród gatunków lokalnie wymarłych znaczący udział mają taksony o nieokreślonej przynależności fitosocjologicznej, wodne, torfowiskowe oraz łąk wilgotnych. Gatunki związane z siedliskami wodnymi oraz cechującymi się wysokim poziomem wód gruntowych stanowią $49 \%$ wszystkich wymarłych.

Stwierdzono następujące prawidłowości: w grupie gatunków wód oligo- i mezotroficznych dużo większe straty zanotowano we florze siedlisk skąpożywnych (klasa Littorelletea - 7 gatunków) niż umiarkowanie zasobnych (klasa Utricularietea - 1); wśród gatunków wód eutroficznych i źródlisk straty dotyczą wyłącznie przedstawicieli wodnych makrofitów (klasa Potametea - 6); spośród gatunków związanych z kompleksem wysokotorfowiskowym do lokalnie wymarłych zaliczono jedynie gatunki reprezentujące rząd Scheuchzerietalia palustris (8), które na torfowisku wysokim są składnikami dolinek; stosunkowo największe straty we florze niskotorfowiskowej zanotowano w grupie związanej z siedliskami neutralnymi i alkalicznymi (rząd Caricetalia davallianae - 5); w grupach taksonów olsowych i szuwarowych stwierdzono jedynie nieznaczny spadek liczby gatunków (odpowiednio 3 i 4); zanik stanowisk terofitów wilgotnych siedlisk mineralnych i namulisk dotyczy tylko gatunków z klasy Isoëto-Nanojuncetea (3); lokalnie wymarłe taksony związane z łąkami wilgotnymi wywodzą się głównie ze zbiorowisk zmiennowilgotnych łąk i ziołorośli nadrzecznych (rząd Molinietalia -4).

Analiza ubywania gatunków w kolejnych okresach badań wykazała, że największe straty we florze stwierdzono po roku 1940 - 63 taksony roślin naczyniowych notowano po raz ostatni w latach 1897-1940, podczas gdy w latach 1809-1896 było takich gatunków 17, a w latach 1941-1979 zanotowano po raz ostatni 12 gatunków. Wśród gatunków notowanych ostatni raz w latach 1897-1940 duży udział miały taksony wód oligo- i mezotroficznych, torfowisk, łąk wilgotnych oraz wrzosowisk, a także gatunki o szerokiej skali fitosocjologicznej.

Ze względu na brak pełnej dokumentacji flory w poszczególnych okresach badań nie jest możliwe prześledzenie etapów jej wzbogacania w gatunki obce siedliskowo i geograficznie. Zasadniczo można przyjąć, że począwszy od roku 1809 liczba gatunków roślin naczyniowych we florze terenu badań stopniowo zwiększała się. W kolejnych okresach badań zanotowano: 1809-1896 - 327 gatunków; 1897-1940 - 545; 1941-1979 - 366 (w tym okresie notowania odnoszą się jedynie do wybranych fragmentów terenu); 1980-1996 - 619; 1997 2004 - 808. Łączna liczba gatunków odnotowanych na badanym terenie stanowi 33\% flory naczyniowej Polski, szacując że współcześnie liczy ona około 2980 gatunków (MireK et al. 2002). 
We florze współczesnej badanego terenu stwierdzono 612 spontaneofitów oraz 196 antropofitów. Wśród gatunków obcego pochodzenia przeważają diafity (76), grupa archeofitów liczy 61 gatunków, kenofitów zaś - 59. Ponad połowę taksonów wśród archeofitów stanowią rośliny bardzo rzadkie i rzadkie. W grupie diafitów i agriofitów brak jest zupełnie gatunków pospolitych i bardzo częstych. Łączny udział gatunków z I i II klasy frekwencji jest najwyższy wśród diafitów (94\%), a wśród kenofitów wynosi od 62\% (hemiagriofity) do $84 \%$ (epekofity).

We florze współczesnej taksony torfowiskowe s.lat. stanowią łącznie 4,7\% ogółu gatunków. Wszystkie gatunki związane z wysokim poziomem wody, czyli rośliny wodne, torfowiskowe, bagienne oraz szuwarowe obejmują łącznie 15,6\% flory. Największy udział we florze mają taksony o nieokreślonej przynależności fitosocjologicznej (33\%). Nieco ponad $19 \%$ flory stanowią gatunki synantropijne, wśród których najliczniejsze związane są z siedliskami ruderalnymi oraz chwastami zbożowymi i okopowymi. Stosunkowo duży udział we florze mają rośliny łąkowe, przy czym znacznie liczniejsze w tej grupie są gatunki związane z siedliskami wilgotnymi ( $9,3 \%$ flory) niż ze świeżymi (3,2\%). Znaczący udział $(8,3 \%)$ mają również taksony żyznych lasów liściastych i zbiorowisk zaroślowych.

We współczesnej florze obszaru badań największy udział mają hemikryptofity $(41 \%)$ oraz terofity (25\%). Fanerofity, geofity oraz hydro- i helofity stanowią odpowiednio 13, 9 i $8 \%$ flory. Najmniej liczna jest grupa chamefitów, które tworzą zaledwie 4\% flory. Wzbogacenie flory w gatunki reprezentujące geofity, fanerofity i terofity może być uznane za przejaw zaburzeń antropogenicznych, gdyż reprezetowane są one głównie przez taksony obce siedliskowo.

Tendencje dynamiczne wybranych grup gatunków we florze współczesnej. Tendencje dynamiczne flory współczesnej zostały scharakteryzowane na podstawie wskaźników apofityzmu ( $\left.\mathrm{I}_{\text {ap }}\right)$ oraz naturalizacji $\left(\mathrm{I}_{\text {nat }}\right)$.

Brak tendencji do zajmowania siedlisk silnie zmienionych ( $\left.\mathrm{I}_{\mathrm{ap}}=0\right)$ stwierdzono u $6 \%$ spontaneofitów, reprezentowanych m.in. przez gatunki charakterystyczne dla wód eutroficznych, torfowisk i kwaśnych lasów bagiennych, olsów i szuwarów oraz łąk wilgotnych. Grupa gatunków nieprzejawiających tendencji do apofityzmu cechuje się stosunkowo wysoką średnią wartością wskaźnika wilgotności i zawartości materii organicznej oraz niską wartością wskaźnika światła.

Gatunki o silnych i bardzo silnych tendencjach do zajmowania siedlisk głęboko przekształconych $\left(51 \% \leq \mathrm{I}_{\text {ap }}\right)$ stanowią $7 \%$ spontaneofitów. Struktura socjologiczna tych syntaksonów wskazuje, że są one reprezentowane głównie przez taksony siedlisk synantropijnych, a zwłaszcza ruderalnych i segetalnych, muraw napiaskowych, ciepłolubnych okrajków i muraw, łąk, namulisk i wilgotnych siedlisk mineralnych oraz gatunki o nieokreślonej przynależności fitosocjologicznej. Do spontaneofitów, które w największym stopniu przywiązane są do siedlisk eu- i polyhemerobnych należą m.in. Aethusa cynapium, Arctium minus, Erodium cicutarium, Juncus compressus, Melilotus alba oraz Trifolium arvense. Średnie wartości liczb wskaźnikowych Zarzyckiego dla wilgotności, trofii i zawartości materii organicznej w tych grupach są stosunkowo niskie, natomiast wskaźnik światła jest relatywnie wysoki.

Spośród antropofitów $18 \%$ wykazuje słabe zdolności do zajmowania siedlisk oligo- i mezohemerobnych $\left(1 \% \leq \mathrm{I}_{\text {nat }} \leq 25 \%\right)$; przeważają wśród nich archeofity. Taksony o silnych i bardzo silnych tendencjach do naturalizacji $\left(51 \% \leq \mathrm{I}_{\text {nat }}\right)$, stanowiące $9 \%$ wszystkich roślin obcego pochodzenia, rekrutują się w większości z kenofitów. Najsilniejsze tendencje 
do zajmowania siedlisk oligo- i mezohemerobnych $\left(76 \% \leq \mathrm{I}_{\text {nat }}\right)$ wykazuje pięć gatunków kenofitów: Elodea canadensis, Lolium multiflorum, Padus serotina, Picea abies oraz Pyrus communis.

Przyczyny przemian flory. Na podstawie analizy archiwalnych i współczesnych map topograficznych, zdjęć lotniczych oraz wybranych pozycji literatury stwierdzono, że głównymi formami antropopresji, które wpłynęły na stan środowiska przyrodniczego badanego obszaru są: melioracje odwadniające i regulacja rzek, użytkowanie łąkarskie, pastwiskowe, rolnicze, eksploatacja torfu, osadnictwo, budowa sieci dróg i transport, gospodarka leśna oraz zaśmiecanie. Nasilająca się antropopresja znalazła odbicie w następujących po sobie zmianach struktury użytkowania terenu. Zmiany te przejawiały się głównie stopniowym zmniejszaniem się powierzchni o najmniejszym stopniu zaburzenia (w latach 1862-1875 stanowiącej $43 \%$ powierzchni terenu, a obecnie zaledwie 4\%) na rzecz terenów użytkowanych rolniczo (współcześnie 65\% powierzchni) oraz zajętych przez zbiorowiska zaroślowe i leśne (22\% powierzchni). Na podstawie map klas pokrycia terenu dla czterech kolejnych przedziałów czasowych wykonano syntetyczną mapę wieku zaburzeń. Wynika z niej, że ponad $80 \%$ badanego terenu była zaburzona w widoczny sposób już w początkowych okresach badawczych, tj. między latami 1862 i 1939. Obszary zaburzone w późniejszych latach to $\mathrm{w}$ przewadze niewielkie powierzchnie zlokalizowane na torfowiskach wysokich i przejściowych lub na ich obrzeżach. Część z nich zamieniono po roku 1939 na użytki rolne, a część została opanowana przez zarośla i lasy.

Analiza związku między przestrzennym zróżnicowaniem flory a oddziaływaniem człowieka i cechami środowiska przyrodniczego, przeprowadzona na podstawie zastosowanych metod wielowymiarowych i analiz przestrzennych, wskazuje na następujące prawidłowości:

- W gradiencie typologicznym siedlisk torfowych flora wykazuje w dalszym ciągu znaczne różnice, związane przede wszystkim z kwasowością i zasobnością siedlisk. Pewna odrębność florystyczna siedlisk wtórnych, ukształtowanych na różnych ekologicznych typach torfowisk, zostaje zachowana nawet wówczas, gdy siedliska poddane są zbliżonym formom antropopresji.

- Na obszarze siedliskowym torfowisk wysokich i przejściowych najmniej drastyczne zmiany we florze powodują eksploatacja torfu i umiarkowane osuszenie podłoża; znaczna modyfikacja flory została stwierdzona na obszarach zaburzonych przez silne odwodnienie, użytkowanie łąkarskie, rolnictwo, transport i budowę sieci rowów odwadniających, natomiast najbardziej radykalne zmiany jakościowe flory następują w miejscach zaśmiecanych.

- W granicach obszaru siedliskowego torfowisk niskich florystycznie najbardziej zbliżone do siedlisk niezaburzonych są tereny kształtowane przez eksploatację torfu i budowę sieci rowów. Znaczną modyfikację flory powoduje silne osuszenie, prowadzące do odsłonięcia podtorfowych utworów mineralnych i gospodarka leśna, natomiast najsilniejszą przebudowę flory zanotowano na siedliskach zaburzonych przez intensywne użytkowanie łąkarskie, rolnictwo, rozwój osadnictwa i transportu, zaśmiecanie, nawożenie obcego substratu i tworzenie sztucznych podłoży.

- Wśród zbadanych zmiennych środowiskowych największy wpływ na przestrzenne zróżnicowanie flory mają: wiek antropogenicznych zaburzeń, charakter utworów powierzchniowych (areał torfu), udział powierzchniowy obszarów leśnych oraz długość dróg na jednostkę powierzchni. Ustalono, że jakość flory współczesnej jest w większym stopniu 
uzależniona od zmiennych związanych ze strukturą użytkowania terenu niż z uwarunkowaniami siedliskowymi wyrażonymi jako geologiczny charakter utworów powierzchniowych.

- Bogactwo florystyczne jest związane z nasileniem takich form antropopresji jak budowa sieci rowów, łąkarstwo, transport i zaśmiecanie.

- Udział gatunków charakterystycznych dla torfowisk wysokich jest pozytywnie związany $\mathrm{z}$ areałem otwartych obszarów poeksploatacyjnych.

- Poziom synantropizacji zależy od formy i natężenia antropopresji - ustalono pozytywny związek między udziałem procentowym kenofitów a udziałem powierzchniowym obszarów zabudowanych i długością dróg oraz liczbą kenofitów i diafitów a intensywnością zaśmiecania. Uwagę zwraca niemal całkowity brak stanowisk gatunków synantropijnych, terofitów oraz antropofitów w granicach torfowisk wysokich i przejściowych.

- Mapa zróżnicowania wartości wskaźnika zawartości materii organicznej w podłożu wskazuje, że gleby bogate w materię organiczną koncentrują się współcześnie w granicach torfowisk wysokich, a także w dolinach rzek Piaśnicy, Białogórskiej Strugi i Czarnej Wdy. Fragmenty terenu najuboższe w humus są natomiast zlokalizowane w rejonie Łąk Dębkowskich, Karwieńskich Błot oraz u podnóża Kęp Ostrowskiej i Sławoszyńskiej. Na obrzeżach torfowisk, które miały w przeszłości charakter organiczno-mineralny, na skutek osuszenia terenu i użytkowania rolniczego, doszło do decesji cienkiej warstwy humusu. Zubożenie gleby w materię organiczną w centrum badanego terenu, np. w rejonie wsi Karwieńskie Błota, jest wynikiem długotrwałej, intensywnej antropopresji (teren najdłużej użytkowany przez człowieka, poddany melioracjom odwadniającym już w XVI wieku).

\section{Wnioski}

- Antropogeniczne przemiany, jakie nastąpiły na torfowiskach przymorskich w wiekach XIX i XX, doprowadziły do zaniku siedlisk ahemerobnych oraz do redukcji przestrzennej i fragmentacji siedlisk oligohemerobnych, przy jednoczesnym wzroście areału siedlisk o wyższych stopniach hemerobii. W efekcie tego procesu doszło do powstania mozaiki siedlisk wtórnych i wybitnego zwiększenia różnorodności florystycznej terenu.

- Obecny stopień synantropizacji flory jest związany nie tylko z formą i natężeniem antropopresji, lecz również z pierwotnym ekologicznym zróżnicowaniem torfowisk, przy czym siedliska torfowisk wysokich i przejściowych cechują się większą odpornością na ekspansję gatunków obcych siedliskowo i geograficznie niż siedliska torfowisk niskich.

- Mimo daleko posuniętej transformacji, przebiegającej przede wszystkim w kierunku eurytopizacji i allochtonizacji, współczesna flora torfowisk przymorskich zachowała część swoistych cech, związanych z charakterem geologicznym i zróżnicowaniem typologicznym siedlisk, a także z położeniem geobotanicznym. Postęp synantropizacji flory na zaburzonych siedliskach torfowych i jego ewentualne skutki w postaci całkowitego zastąpienia flory naturalnej przez wtórną lub zatarcia różnic florystycznych między siedliskami wysokotorfowiskowymi a niskotorfowiskowymi wymaga dalszych badań.

DSc. Agnieszka Budyś

Department of Plant Taxonomy and Nature Conservation

Laboratory of Geobotany and Nature Conservation

University of Gdańsk

Al. Legionów 9

PL-80-441 Gdańsk

e-mail: bioabud@univ.gda.pl 
